\title{
MPRA
}

Munich Personal RePEc Archive

\section{Liquidity Risk and the Credit Crunch of 2007-2009: Evidence from Micro-Level Data on Mortgage Loan Applications}

\author{
Antoniades, Adonis
}

1 July 2013

Online at https://mpra.ub.uni-muenchen.de/49270/

MPRA Paper No. 49270, posted 24 Aug 2013 11:33 UTC 


\title{
LIQUIDITY RISK AND THE CREDIT CRUNCH OF 2007-2009: EVIDENCE FROM MICRO-LEVEL DATA ON MORTGAGE LOAN APPLICATIONS*
}

\author{
ADONIS ANTONIADES
}

July 1, 2013

\begin{abstract}
I test the hypothesis that the banks' exposure to liquidity risk contributed to the contraction of mortgage credit during the financial crisis of 2007-2009. I use micro-level data on mortgage loan applications to control for variation in demand conditions and find that lenders who relied less on core-deposit funding or who had larger off-balance sheet exposure to credit lines, exhibited a sharper decline in their propensity to approve loan applications. These two sources of liquidity risk jointly accounted for a $\$ 41.5$ billion - $\$ 61.9$ billion contraction of mortgage credit during $2007-2009$, or $5.2 \%-7.8 \%$ of total mortgage originations during this period.
\end{abstract}

Keywords: liquidity risk, bank lending channel, lines of credit, core deposits, real estate, mortgage lending

JEL Classification: E51, G01, G11, G21

*The author is Economist at the European Central Bank (joining August 2013), can be contacted by email at aa2632@columbia.edu, phone at (646) 280-9395, mail at 450 W 42nd St Apt 14D, New York, NY 10036-6871. I would like to thank Charles Calomiris, Pierre-André Chiappori, Perry Mehrling, Ricardo Reis, and Bernard Salanié for their continuous feedback, guidance and support. This work has also benefited immensely from helpful discussions with Alexis Antoniades, Katherine Ho, Alexander Michaelides, Miguel Morin, Serena Ng, Tomasz Piskorski, Michael Riordan, and Daniel Wolfenzon, as well as from the input of seminar participants at Columbia University, the Central Bank of Cyprus, the Federal Reserve Bank of San Francisco, the Bank for International Settlements, the European Central Bank, Goizueta Business School, Brown University, Foster School of Business, and NYU Abu Dhabi. All errors are my own. 


\section{Introduction}

The financial crisis of 2007-2009 brought about a severe contraction of credit. While much attention has been rightfully devoted to the causes of the crisis, the mechanisms driving the contraction of credit experienced during the crisis received less attention. Understanding these mechanisms is a key issue in enhancing policy-making to prevent and to respond to such crises in the future.

Two broad categories of mechanisms may account for the contraction of credit. On the demand side, deleveraging by households and firms should have caused the amount of credit demanded to drop. On the supply side, the deterioration in the financial condition of banks may have produced a lower propensity to lend. Disentangling the demand from the supply channel is a major challenge to the identification of the independent effect of each channel on credit.

This paper seeks to empirically identify the presence of a particular supply-side mechanism and quantify its impact on mortgage credit. I focus on liquidity risk, the possibility that a bank may suffer an adverse shock to its liquidity position, and address two specific questions: (1) did funding illiquidity pressures on banks, or on their non-mortgage loan customers, precipitate a contraction of mortgage lending, and (2) if such an effect was in place what was its economic magnitude? To answer these questions one needs a model of credit origination and an identification strategy to separate demand-side from supply-side effects.

Concerns about liquidity risk became particularly relevant during the financial crisis of 2007-2009, and two recent studies have empirically identified a contractionary effect of liquidity risk on the supply of credit during this period, Ivashina and Scharfstein (2010) for the syndicated loan market and Cornett et al. (2011) for the aggregate lending portfolio of commercial banks. Due to the nature of the syndicated loan market, Ivashina and Scharfstein (2010) work with a small sample, and proxy for credit demand conditions with borrower characteristics, such as the sales volume of the borrower. Cornett et al. (2011) use a much 
larger dataset and rely on balance-sheet ratios and geographical presence indicators from FDIC Summary of Deposits to control for demand conditions; identification is driven by variation in the loans that are held on balance-sheet, a quantity which incorporates no information about originated loans that were sold or, importantly, about loan applications that were declined.

I extend the empirical findings of Ivashina and Scharfstein (2010) and Cornett et al. (2011) in three ways. First, I use micro-level data on individual mortgage loan applications, which provides me with information on both the quantity of credit demanded and the characteristics of each individual loan applicant. The level of detail in the data permits a more complete treatment of demand-side effects than has been possible in previous studies. Second, I develop a two-stage empirical methodology which allows me to separate the demand for credit from the supply of credit and thereby estimate the independent effect of liquidity risk on the supply of credit. Third, I focus on the mortgage market and produce the first estimates of the impact of liquidity risk on the volume of originations in this important sector of finance during the financial crisis of 2007-2009.

My identification strategy proceeds in two stages. The first stage identifies the supply of credit by controlling for a wide array of demand-side determinants of credit. The second stage uses extensive data on the financial condition of lenders to identify the effect of liquidity risk on the supply of mortgage credit.

In the first stage, to control for the demand channel, I employ individual mortgage loanlevel data for 2004-2010 provided through the Home Mortgage Disclosure Act (HMDA). The data suggest that demand-side drivers of credit activity were important during the crisis. Demand for mortgage credit declined dramatically after 2006, and by 2010 the number of applications to commercial banks dropped to approximately one quarter of its peak, 2006 level.

The identification strategy in the first stage relies on heterogeneity across borrowers to 
decompose the decision of whether to approve or decline a loan application into demand-side and supply-side drivers. Conditioning on an individual loan application, I model the supply of credit as targeting a cutoff on the distribution of borrower characteristics, and estimate a binary choice model of the loan approval decision. The advantage of focusing on the approval decision is that it focuses on the flow of new credit and takes into account a broad range of lender outcomes, including credit rationing. ${ }^{1}$ Variation across lenders in the supply of credit is captured by lender-year fixed effects. I control for demand-side effects by including a host of borrower/loan characteristics and saturating the model with location-year fixed effects.

With the first stage extracting a measure of the supply of credit from the lending decision, in the second stage I estimate the effect of liquidity risk on credit supply. Specifically, I examine how high reliance on wholesale funding ${ }^{2}$ and high off-balance sheet exposure to unused lines of credit $^{3}$ affected the supply of credit in the mortgage market during the financial crisis.

To identify the effects of the two sources of liquidity risk on the supply of credit, I rely on extensive financial data obtained from the Reports of Condition and Income (Call Reports) and exploit cross-sectional differences in the levels of exposure of lenders to each source of liquidity risk. I adopt a structural break framework, where the effect of liquidity risk is captured by the changes from baseline pre-crisis levels in the average level of the coefficients for unused lines of credit and reliance on wholesale funding. ${ }^{4}$ I use year 2004 as the baseline

\footnotetext{
${ }^{1}$ These supply-side effects would have been harder to identify by employing an approach which infers credit supply from variation in the stock of loans held on a bank's balance sheet. The maturity structure of the bank's loan portfolio will induce, for example, cross-sectional variation in the stock of loans across banks and over time, but this variation is not driven by what we typically think of as frictions in the supply channel. In addition, the volume of loan originations largely depends on the volume of loan applications which is in turn partly determined by demand-side mechanisms; a decrease in the stock of loans could thus merely reflect declining numbers of loan applications and be unrelated to supply considerations.

${ }^{2}$ Wholesale funding is the part of total funding that does not come from core deposits. The two terms will be used frequently in this paper and their effects can be interpreted in relation to each other (i.e. high reliance on core-deposit funding means low reliance on wholesale funding and vice versa). Examples of wholesale sources of funding are repurchase agreements and uninsured time deposits.

${ }^{3}$ Unused lines of credit are issued by banks to their customers and they represent commitments to supply credit to the customer, on the customer's request, up to a maximum credit limit. Funding illiquidity strains on a bank's customers can lead to increased requests for credit, thus imposing a liquidity strain on the bank's balance sheet.

${ }^{4}$ In a later section, I discuss how the qualitatively similar framework employed in Cornett et al. (2011), which interacts the TED spread with the two variables that capture the degree of exposure to liquidity risk, naturally follows from the structural break framework I employ in this paper.
} 
pre-crisis year, and track the structural breaks in the coefficients for the period extending from one year before to one year after the crisis (2006-2010).

I find that lenders which were more greatly exposed to liquidity risk, through high levels of unused lines of credit and low levels of core-deposit funding, contracted their supply of mortgage credit more during the crisis. The negative impact of high exposure to unused lines of credit on the supply of mortgage credit came to full effect as early as 2006, but did not extend past 2008, whereas the effect of core-deposit funding peaked in 2008 and extended, albeit with diminished intensity, past the end of the crisis in 2009. Estimates on a split sample show that the contraction was sharper for larger lenders, which had the largest exposure to liquidity risk. The results are robust to a number of alternative specifications.

Liquidity risk had an economically significant effect on mortgage credit during the financial crisis. I estimate that the change in the lenders' credit response to high levels of liquidity risk during 2007-2009 caused a total contraction of $\$ 41.5$ billion - $\$ 61.9$ billion, or 5.2\%-7.8\% of total mortgage originations during that period. Measured as the dollar volume of mortgage originations, the contraction was more severe in 2007 ( $\$ 20.9$ billion - $\$ 31.9$ billion); as a percentage of the annual volume of originations, the largest effect was in 2008 (8.1\%-9.9\%).

I also estimate the increase in mortgage originations that would have occurred had the banks operated during the crisis of 2007-2009 with their levels of exposure to each source of liquidity risk reduced by one standard deviation. The combined increase in the dollar volume of mortgage originations over the period 2007-2009 would have been $\$ 24.2$ billion $\$ 27.4$ billion, or 3.1\%-3.5\% of total originations during that period. The dollar volume of originations would have increased most significantly in 2007 ( $\$ 12.5$ billion - $\$ 15$ billion) but the largest percentage increase would have occurred in 2008 (4.5\%-4.6\%).

The rest of the paper proceeds as follows. Section II. discusses related work and places the contributions of this study within the preexisting literature on credit supply shocks. Section III. describes a stylized model of the loan approval decision which treats the supply 
function as targeting a threshold on the distribution of borrower characteristics, and employs a balance sheet framework to draw the connections between liquidity risk and the supply of credit. Section IV. describes the data sources used and discusses sample construction, and Section V. presents summary statistics which track aggregate demand and supply conditions in the mortgage market moving through the crisis. Section VI. discusses the main challenges to identification and develops a two-stage empirical strategy to address them. Section VII. presents the main results of the paper for the two stages of estimation. Given the presence of a large-small bank dichotomy in the results for the second stage, I explore these differences in detail in this section. Section VIII. tests the results for robustness against a number of alternative specifications, Section IX. estimates the economic significance of the effect of liquidity risk on credit origination in the mortgage market, and Section X. concludes.

\section{Literature Review}

This paper builds on three key insights from the literature. First, to identify supply-side effects in lending one must carefully control for demand-side effects. Second, through balance sheet constraints, funding shocks and shocks specific to a particular line of business of a bank can transfer across the balance sheet and affect the supply of credit in another line of business. Third, the recent financial crisis put a strain on both the asset side and the liability side of the banks' balance sheets, through rapid drawdowns on lines of credit and funding illiquidity pressures in the markets for wholesale funding respectively.

Empirical studies have exploited exogenous shocks to funding to show that adverse shocks to liquidity can lead to a contraction of credit supply. Early studies did not adequately control for demand-side factors and could have thus been estimating demand-side effects. ${ }^{5}$ The prevalent treatment for demand in the literature is the inclusion of fixed effects for the location of the bank's headquarters and the inclusion of composition ratios of the lender's

\footnotetext{
${ }^{5}$ The reader can refer to Kashyap and Stein (2000) for a discussion of alternative interpretations involving demand-side explanations of the bank channel identified in Bernanke and Blinder (1992) for example.
} 
loan portfolio to capture the degree of exposure of the lender to business cycles in different parts of the economy. ${ }^{6}$

Due to the scarcity of micro-level credit data, more refined treatments for demand have thus far been limited to a few recent studies that employ data on individual loans to examine questions relating to the supply of credit. $^{7}$ This paper contributes to this strand of the literature by utilizing data on individual mortgage loan applications to study the effect of liquidity risk on the supply of mortgage credit during the financial crisis of 2007-2009.

Funding shocks can result from a tightening of monetary policy, and Kashyap and Stein (2000) show that such shocks affect lending through the bank lending channel of monetary transmission. ${ }^{8}$ They also show that this channel is weaker for larger banks, suggesting that more extensive access to capital markets makes it easier for larger lenders to absorb the shock by substituting between sources of funding. Campello (2002) provides further evidence on this point, by showing that the effect of the bank lending channel is dampened by the existence of internal capital markets available to banks belonging to bank holding companies.

Internal capital markets can operate across borders. Cetorelli and Goldberg (forthcoming) track the cross-border flow of funds for global banks and show that such flows help dissipate the impact of local shocks to liquidity. A similar interpretation of these results suggests that negative shocks can be transmitted across markets/borders. Shocks arising from the exposure of foreign parent banks to deteriorating stock market conditions in Japan, for example, can adversely affect lending in their US branches, as in Peek and Rosengren (1997). Shocks can also originate in one loan market and adversely impact lending in another market, as with

\footnotetext{
${ }^{6}$ See, for example, Cetorelli and Goldberg (forthcoming), Cornett et al. (2011), Aiyar, Calomiris and Wieladek (2012)

${ }^{7}$ Dell'Ariccia, Igan and Laeven (2008) investigate the effect of competition on the supply of mortgage credit before the crisis of 2007-2009, Loutskina and Strahan (2009) the effect of deposits costs and asset liquidity on the supply of jumbo vs conforming loans in the US, Puri, Rocholl and Steffen (2011) the effect of exposure of German savings banks to the US subprime crisis on the supply of retail lending in Germany, Jimenez et al. (2012) the effect of monetary policy and balance sheet strength on the supply of C\&I loans in Spain.

${ }^{8}$ There are do exist other examples of source of funding shocks. Paravisini (2008) studies the effect of government interventions in Argentina, Khwaja and Mian (2008) study the effect of a run on dollar deposit accounts due to nuclear testing in Pakistan. The results in these studies uniformly indicate that negative shocks to liquidity result in a contraction of credit.
} 
the deterioration of conditions in the commercial real estate market in Japan, which led to a contraction of both lending and real activity in the US (Peek and Rosengren (2000)).

The common theme behind these studies is the international propagation of shocks. Viewed more broadly, the results also suggest a model of banks running distinct lines of business, yet operating on an aggregate balance sheet relying on a common pool of liquid assets and/or capital. Through these balance sheet constraints, shocks in one line of business can transfer across the balance sheet and affect the supply of credit in another line of business. My paper identifies a localized version of these mechanisms and tracks the effect of exogenous shocks to liquidity stemming from high exposure to unused lines of credit and wholesale funding on the supply of mortgage credit.

During the financial crisis of 2007-2009 the primary shock to the liability structure of banks did not come from monetary policy adjustments but rather from the funding illiquidity experienced in the markets for wholesale funding. Adrian and Shin (2009) study security broker dealers and find a procyclical relationship between asset growth and leverage. They find the margin of adjustment to come through collateralized borrowing and lending (repurchase agreements) and, on the basis of this relationship, attribute the severe contraction of market credit during the crisis to the severe stresses in the markets for wholesale funding. Gorton and Metrick (2012) show that the weakening of the securitization market for subprime mortgages was not the primary shock that caused systemic problems to the banking system. Rather, the first systemic event of the crisis occurred in the money markets when concerns about repo collateral and bank solvency aggregated up to the first run on repo in August 2007. Schwarz (2010) finds that at that same month liquidity started accounting for an increasingly larger portion of the spreads in the interbank market and had surpassed the contribution of interbank credit risk by April 2008, a result she ascribes to deteriorating market liquidity conditions and the pricing of liquidity risk. Examining commercial banks, Ratnovski and Huang (2009) show that Canadian banks that relied more on core-deposit 
funding fared better in a number of performance metrics than their counterparts did during the crisis.

Further strains to liquidity can come from off-balance sheet exposure to lines of credit previously issued by the bank. Firms, for example, establish lines of credit with banks as an ex-ante contract to insure against states with negative liquidity shocks (as in Calomiris (1989), Holmstrom and Tirole (2000)). Ivashina and Scharfstein (2010) provide evidence of increased use of credit lines by firms during the crisis of 2007-2009, and Campello et al. (2011) show how companies substituted between internal liquidity and lines of credit during the crisis. Liquidity pressures on a bank's customers can thus be transmitted to a bank's balance sheet through this "drawdown" channel.

Though the risks of withdrawal of short-term funds and drawdowns on lines of credit both require the buildup of liquid asset buffers, Kashyap, Rajan and Stein (2002) develop a theoretical framework to show the synergies that arise from an imperfect correlation between deposit withdrawals and line of credit drawdowns. When such an imperfect correlation exists, the stock of liquid assets maintained by banks can be lower than if the shocks were highly correlated. ${ }^{9}$ Gatev, Schuermann and Strahan (2009) show empirically that these hedging synergies are particularly strong during times of low market liquidity supply, as transaction deposits flow into banks at the same time as drawdowns on credit lines increase.

Examining the effect of these two sources of liquidity risk during the financial crisis of 2007-2009, Ivashina and Scharfstein (2010) show that high exposure to short-term debt and unanticipated drawdowns on lines of credit, due to high levels of co-syndication of revolving lines with Lehman, led to a decrease in new credit origination for large syndicated loans. Using a larger sample and focusing on the aggregate lending portfolio of banks, Cornett et al. (2011) show that exposure to the same two sources of liquidity risk resulted in liquidityhoarding and a contraction of bank credit during the crisis. Identification in both of these

\footnotetext{
${ }^{9}$ Gatev, Schuermann and Strahan (2007) show that during the 1998 crisis, funds flew into banks and the cross-sectional distribution of these inflows favored banks that relied more on transaction deposits as a source of funding.
} 
studies is limited by the lack of precise data on demand conditions during this period.

This paper is more closely related to Ivashina and Scharfstein (2010) and Cornett et al. (2011). The main contribution is the utilization of micro-level data on mortgage loan applications, which allows me to isolate the effect of liquidity risk on credit with a more precise treatment of demand effects than has been possible in these two studies. I develop a twostage identification strategy which in the first stage separates the demand for credit from the supply of credit, and in the second stage estimates the causal effect of liquidity risk on credit supply. In addition, I bring this question to the domain of mortgage lending and produce precise estimates of the impact of liquidity risk on the volume of originations in the mortgage market during the recent financial crisis.

\section{Conceptual Framework}

Consider the stylized model of the loan approval process shown in panel (a) of Figure I. In this model the demand side is represented by a distribution of borrower characteristics. One can think of the distribution of characteristics as collapsing into one dimension the price-adjusted risk level of each borrower, which decreases as we move toward the right tail of the distribution. Loan supply approval targets a distribution cutoff. Applications from borrowers to the right of the cutoff are approved and those from borrowers to the left of the cutoff are declined. The supply threshold is set in accordance with an underlying upwardsloping marginal cost curve, and it can move to the left or to the right as a result of a decline or rise in marginal costs respectively.

In this framework, approval rates can change either due to shifts in demand drivers or shifts in supply drivers. Shifts in demand drivers are represented by a change in the distribution of borrower characteristics in the pool of applicants ${ }^{10}$ and shifts in supply drivers

\footnotetext{
${ }^{10}$ Changes in the distribution of borrower characteristics was evident even before the crisis. Demyanyk and Van Hemert (2008) show that the quality of borrowers deteriorated in each of the six years leading up to the crisis and that to some extent the lenders were aware of the trend as was evidenced in the pricing of risk in mortgage rates.
} 
are represented by a shift in the approval cutoff. Panel (b) shows a scenario in which borrower characteristics shift in the direction of higher risk, and at the same time the supply approval threshold shifts in the direction of tighter lending standards. Both of these movements in isolation would have resulted in a decrease in approval rates, and it is this simultaneous shift in both demand and supply drivers that poses the fundamental challenge to the identification of supply effects in lending. This paper relies on the use of individual loan application data to purge the approval decision from demand-side effects and thus identify supply effects in the contraction of credit.

Liquidity risk is the possibility that a bank may suffer an adverse shock to its liquidity position. Shocks to a bank's liquidity position can affect credit supply because of the banks' central role in liquidity provision and the interconnections between the different components of a bank's balance sheet. ${ }^{11}$ Consider the stylized balance sheet and off-balance sheet structure shown in panel (a) of Figure II. Banks rely upon a combination of core deposits and wholesale funding, invest those funds in a combination of liquid and illiquid assets, and hold capital to absorb losses on their loan portfolio. In addition, banks have issued a number of commitments to fund loans, commitments which must be honored at the request of the counterparty to the agreement; these commitments are normally referred to as lines of credit. $^{12}$

Consider first what happens when a source of wholesale funding is withdrawn. The bank will reduce its level of exposure to wholesale funding but will at the same time dishoard its liquid asset holdings by an equal amount in order to settle the account. ${ }^{13}$ When a bank customer draws down on a line of credit, the off-balance sheet exposure of the bank decreases and, to fund the loan, an equal amount of liquid assets is converted to illiquid loans (i.e.

\footnotetext{
${ }^{11}$ See Berger and Bouwman (2009) for the construction of a measure of liquidity provision based on the composition of assets and liabilities on a bank's balance sheet.

${ }^{12}$ The terms "loan commitments" and "lines of credit" will be used interchangeably henceforth

${ }^{13}$ One can alternatively think about the impact of core-deposits, a high dependence on which was shown in Gatev, Schuermann and Strahan (2007) to result in increased inflows of funds and can thus help a bank raise its liquid asset buffers during times of low market liquidity
} 
to provide liquid funds to the borrower in exchange for an illiquid obligation for future repayment). Similarly, when a bank originates a new mortgage loan, it dishoards part of its liquid assets to fund the illiquid loan. Panels (b)-(d) of Figure II illustrate balance sheet adjustments for a $\$ 1$ activity flow in each of the three aforementioned scenaria respectively.

Two things are key from the above discussion. First, the bank does not control the flow of liquid funds in the first two cases, since actions exogenous to the bank's liquidity management operations determine stresses in the markets for wholesale funding or a customer's decision to draw down on a line of credit; the bank, however, has full control over the lending decision in the third case. Second, in this stylized world, banks hold liquid assets to satisfy two competing objectives: (a) they must be able to absorb negative shocks to liquidity from exogenous withdrawals of wholesale funding and/or drawdowns on lines of credit, and (b) at the same time they would like to be able to invest in positive NPV projects in the mortgage market.

Though banks normally retain a buffer of liquid assets to accommodate withdrawals of funds and drawdown requests, any increase in the possibility of a shock to liquidity will lead banks to allocate a higher portion of the stock of liquid assets towards absorbing the shock and a smaller portion towards new mortgage loan origination; it is through this mechanism that liquidity risk may affect the supply of credit.

This paper empirically corroborates the mechanisms described above. I first identify supply effects in credit provision in the mortgage market. I then show that the supply of credit in this market contracted due to (i) an increase in demand in another loan market, coming from rapid drawdowns on unused lines of credit, and (ii) funding stresses due to high reliance on wholesale funding, the markets for which experienced rapidly deteriorating conditions during the crisis. 


\section{Data Sources}

To identify the effect of liquidity risk on mortgage lending I compile data from two different sources: home mortgage application data from the Home Mortgage Disclosure Act (HMDA) and bank financial data from the quarterly Reports of Condition and Income (Call Reports).

\section{A. Mortgage Loan Data (HMDA)}

HMDA was enacted by Congress in 1975 and implemented by the Federal Reserve Board's Regulation C. It requires lending institutions to report data on mortgage loan applications and its purpose is to enhance the enforcement of anti-discriminatory laws and publish information that would guide public investment in housing. The database covers over $90 \%$ of all lending activity in the home mortgage market, with reporting requirements effectively resulting in the exclusion of small lenders in rural areas (Dell'Ariccia, Igan and Laeven (2008)). It reports the year of application (but not exactly when during the year the application was filed), loan attributes (amount, purpose, outcome, etc), borrower characteristics (income, sex, race, etc), as well as demographic variables for the location in which the property is located (median salary, percentage of population that are minorities, etc).

Importantly, this dataset provides information about the lending decision at the point of application. This decision is solely controlled by the lender and is a much more informative measure of lender behavior than aggregate measures of lending, such as variation in the stock of loans on a bank's balance sheet. Changes in the size of a bank's loan portfolio, for example, may reflect the maturity structure of loans or drawdowns on lines of credit,

neither of which are directly controlled by the lender. In addition, measures of aggregate lending drawn directly from the bank's balance sheet largely ignore the characteristics of the applicants and local market conditions, thus introducing demand-side bias to the estimation of supply effects in credit.

I first drop from the sample lenders that are not commercial banks, and omit loan appli- 
cations that do not correspond to homes in MSA areas. Then, following Dell'Ariccia, Igan and Laeven (2008), I drop applications with loan amounts smaller than $\$ 1,000$ (because the loan amount is reported in thousands and rounded to the nearest integer) or those with income equal to $\$ 1,000$ (because income is left-censored at that value). I then drop loans for multi-family dwellings, federally insured loans and refinancing loans. Multi-family dwellings are sizeable structures that share risk characteristics that are significantly different from those of 1-4 family dwellings, and are treated as a separate category of mortgage loans by banks (bank financial reports make that distinction too). Federally insured mortgage loans and refinancing of mortgage loans have different risk profiles and information structure than those of new, non-insured mortgage loans, and are thus expected to be subject to different

decision rules. Finally, I restrict attention to loans that resulted in one of the following actions: (1) lender approved and borrower execution, (2) lender approved but no borrower execution, and (3) lender denial. Thus, I drop repurchases of already originated loans by a financial institution, entries for which the application was withdrawn by the applicant, and loan applications that were not pursued further due to incomplete information. I use year 2004 data as the pre-crisis baseline year, and years 2006-2010 to span the period from one year before the crisis to one year afterward.

\section{B. Bank Financial Data (Call Reports)}

I obtain financial data for lending institutions from the Reports of Income and Condition for commercial banks ("Call Reports") made available online in summary form by the Federal Reserve Bank of Chicago. The reports cover all commercial banks, and contain detailed financial data in a number of different schedules (balance sheet, income statement, securities holdings, etc).

Different institution types can be identified by the regulatory authority to which they report. The paper's focus is on commercial depository institutions, and these institutions 
report to one of three regulatory bodies: the Board of Governors of the Federal Reserve System (FRB), the Federal Deposit Insurance Corporation (FDIC), and the Office of the Comptroller of the Currency (OCC). Other institution types, such as thrifts, credit unions, etc... operate under different legal frameworks and corporate governance structures and to achieve uniformity in the sample are excluded from the analysis. The matching is done between the HMDA institution number (Respondent_ID in the data) and the appropriate institution number in the "Call Report" determined by the regulatory entity responsible for overseeing the operations of the financial institution. That is, the call report identification number for banks regulated by the FRS, the FDIC certificate ID for banks regulated by the FDIC, and the OCC ID for banks regulated by the OCC. As a number of studies have documented the operation of internal capital markets for banks belonging to bank holding companies, ${ }^{14}$ financial data are aggregated up to the holding company level.

\section{Summary Statistics}

Figure III plots the path of mortgage loan originations measured both as the total number and the total dollar volume for the period 2004, 2006-2010. The variation over time shown in Figure III is striking. Mortgage loan originations peaked in 2006 and then fell sharply during 2007-2008. The slide in originations continued at lower rates after that period, and the total number of originations fell to about a third of its 2006 peak level by 2010 .

[Figure III about here]

Figure IV traces one of the major drivers of the precipitous fall in loan originations back to the rapidly declining numbers of loan applications. This decline may have been driven by both demand-side and supply-side factors. The impact of loan supply on the number of applications is mostly an aggregate effect and not likely to generate any significant cross-

\footnotetext{
${ }^{14}$ Campello (2002), Cetorelli and Goldberg (forthcoming) for example
} 
sectional variation across lenders. ${ }^{15}$ As discussed earlier, this means that estimates for the effect of liquidity risk on credit supply are conservative estimates of the full effect, since they do not account for aggregate supply effects.

To the extent that the drop in loan applications is non-uniform in the cross-section of lenders, this graph also suggests that simple balance-sheet measures of credit supply may well be capturing area-of-operation (demand-side) effects rather than true supply effects. Such variation in demand conditions would not be captured by location or lender fixed effects, because it is very likely to vary with time during a financial crisis. Another limitation of balance-sheet measures of supply is that they only capture variation in the loans that are held on balance-sheet, a quantity which incorporates no information about originated loans that were sold and, more importantly, about loan applications that were declined.

[Figure IV about here]

Figure $\mathrm{V}$ plots loan approval rates against time and traces part of the contraction of lending back to lower approval rates. We can see that approval rates started dropping as early as 2006 but then partly recovered in 2009-2010. The drop in approval rates could have been driven by a shift in the distribution of borrower characteristics (demand-side effect) or by a shift in the approval threshold targeted by banks on that distribution (supply-side effect). The identification challenge is to disentangle these two effects and the identification strategy proposed in the next section robustly does so. The results will show that important supply-side factors affected approval decisions, and that liquidity risk was driving part of the decline in approval rates. ${ }^{16}$

[Figure V about here]

\footnotetext{
${ }^{15}$ Cross-sectional variation in the number of applications generated by supply-side drivers would require informed applicants who can analyze the financial condition of lenders and who would form a preference for applying for mortgage loans to financially healthier lenders. It is not immediately clear that mortgage borrowers exhibit such behavior, but this concern is nonetheless addressed in more detail in the section on robustness

${ }^{16}$ Figures III-V display preliminary summary statistics on aggregate trends in the mortgage loan market. Being aggregates, these trends could be hiding the important cross-sectional effects that the empirical strategy will identify. Extrapolations from these initial findings to cross-sectional implications should thus be treated with caution.
} 
Table II displays summary statistics for the distribution of applicant/loan characteristics during the period 2004, 2006-2010. Moving through the crisis, the average applicant has a higher income and buys properties of higher value. Loan-to-income ratios drop somewhat from 2004. The data also show a decline in the proportion of minority applicants in the applicant pool. Moving through the years of the crisis, we also observe an initial drop in loan applications for home-purchase loans, as well as for applications for properties under a first-lien; both of these trends start reversing as we move out of the crisis.

[Table II about here]

Table III provides summary statistics for lenders, with the sample split between small and large lenders. ${ }^{17}$ The financial variables are reported at end of year, fourth quarter), levels. ${ }^{18}$ Smaller lenders are better capitalized and hold higher levels of asset liquidity on their balance sheets. Asset liquidity has been declining for both large and small lenders through the end of 2008, with a sharp increase noted by the end of 2009. Profitability for both categories of lenders experienced a sharp decline in 2008 with further losses in 2009. Smaller lenders hold a larger percentage of illiquid assets in residential real estate loans ${ }^{19}$ and subsequently experienced higher default rates on such loans as a percentage of total assets. Exposure to commercial and industrial loans is, as expected, considerably higher for large lenders.

\section{[Table III about here]}

Importantly, smaller lenders are less exposed to liquidity risk than larger lenders, as they are funded to a greater extent by core deposits and hold smaller off-balance sheet exposures to unused lines of credit for both real estate and non-real estate loans. Figures VI-VII plot the paths of these two sources of liquidity risk moving through the crisis. Besides the

\footnotetext{
${ }^{17}$ The threshold used is $\$ 1$ billion, against which the bank asset size (averaged over all observations for the bank in the dataset) is compared for categorization purposes. The reasons behind the choice of threshold and averaging measure are discussed in Section VII..

${ }^{18}$ This was done to be consistent with the model used in the second stage, where lending activities during year $\mathrm{T}$ are modeled as being dependent on end-of-year T-1 financial variables

${ }^{19}$ Residential real estate loans are defined as the sum of open-end and closed-end residential real estate loans
} 
aforementioned gap in exposure levels, we can see an initial decline in core-deposit funding, a trend, however, which started reversing in 2008. The level of exposure to unused lines of credit for real estate loans peaked at the beginning of 2006, but rapid drawdowns led to a steady decline which intensified in 2008. These plots suggest a pattern in the timing of shocks to liquidity during the crisis, with drawdowns on lines of credit leading the strains experienced in the markets for wholesale funds.

[Figures VI-VII about here]

\section{Identification Strategy}

To aid the discussion of the main challenges associated with identifying supply effects in lending, consider the simple reduced-form model shown in Equation 1, where $L_{i t}$ is a measure of the lending propensity of bank $i$ in time period $t, X_{i t-1}$ is a vector of time-lagged bank balance sheet characteristics and $u_{i t}$ is an idiosyncratic error term. I assume lending propensity to be determined centrally based on the financial condition of the lender at the beginning of the year, and once it is determined subsequent adjustments throughout the year take time to percolate down to the various branches; lending propensity is thus assumed to stay constant throughout the year.

$$
L_{i t}=\beta_{t} X_{i t-1}+u_{i t}
$$

The primary identification challenge is that determinants of credit supply in $X_{i t-1}$ may be correlated with unobservable demand conditions in $u_{i t}$, thus giving rise to omitted variable bias. For example, assume that $X_{i t-1}$ contains some measure of lender profitability. High unemployment rates in the region of operation of the bank would correlate negatively with both bank profitability and lending propensity, ${ }^{20}$ and would induce a positive bias on the

\footnotetext{
${ }^{20} \mathrm{~A}$ high level of unemployment will adversely affect the risk profile of potential borrowers and will thus correlate negatively with lending propensity.
} 
estimated coefficient of the effect of profitability on lending propensity. In order to identify supply effects in credit, it is therefore essential that one begin with a measure of lending propensity that is uncorrelated with demand-side determinants of credit.

Assuming that such a "demand-free" measure of lending propensity is available, the second major challenge is to ensure that the balance sheet variables used to capture the effect of shocks to liquidity on credit supply are not set endogenously by the bank. For example, high levels of risk aversion will both decrease lending propensity and increase liquid asset holdings, thus inducing a negative bias on the impact of liquid asset holdings on lending propensity. $^{21}$

The identification strategy consists of two stages of regressions each designed to address one of these two sets of challenges. In the first stage, conditioning on a loan application, the lender's decision of whether to approve or decline the application is decomposed into distinct components belonging either to the supply side or to the demand side of credit. In the second stage, the estimated supply-side component of the lending decision is regressed on a set of bank balance sheet variables that capture the degree of exposure to exogenous shocks to liquidity. The two variables of interest are the lender's exposure to high levels of unused lines of credit and the lender's degree of reliance on core-deposit funding. Definitions for the explanatory variables used at each stage are shown in Table I.

\section{A. First Stage}

The first stage follows directly from the stylized model presented in Figure I. More specifically, conditioning on a mortgage loan application, I estimate the binary logit model of the lending decision shown in Equation 2, to extract a supply-side measure of lending propensity. In the context of modeling the lending decision, a non-linear model is more appropriate than a linear one because it does not make the unrealistic assumption of uniform marginal

\footnotetext{
${ }^{21}$ This is in essence another instance of omitted variable bias.
} 
probability. ${ }^{22}$

$$
\operatorname{Pr}\left(A_{i j n t}=1 \mid i, j, t, X_{n}\right)=\Lambda\left(L_{i t}+C_{j t}+\lambda_{t} X_{n}\right)
$$

$A_{i j n t}$ is a binary variable capturing the outcome of the application, made to lender $i,{ }^{23}$ for a property located in county $j$, by borrower $n$, in year $t . \Lambda($.$) is the logistic function, L_{i t}$ and $C_{j t}$ are the coefficients for lender-year and county-year dummies respectively, and $X_{n}$ is a vector of borrower/loan characteristics.

The coefficients for the lender-year dummies $\left(L_{i t}\right)$ identify the supply-driven component of lending propensity. The coefficients for borrower characteristics and location-year dummies capture demand-side effects. I include a rich set of demand-side controls to ensure that the supply-side measure of lending propensity is free from demand-side bias.

All variables are time-interacted, to allow for the banks' responses and market model to evolve flexibly over time. Such flexibility is crucial to identification, as the market's assessment of risk for individual borrower characteristics and geographic locations is expected to have changed in response to time-varying conditions and information about the market. For example, areas in which credit standards may have been relaxed in response to rising housing prices prior to the crisis, may have also experienced severe credit tightening conditions due to the collapse of housing prices during the crisis. It is thus important to interact location with time in order to purge variation in the lending decision from variation in local demand conditions.

Estimation of the model is computationally prohibitive due to the inclusion of thousands of dummy variables estimated over millions of observations; each year is thus estimated separately. Also, since the dataset includes many banks with insignificant lending activity, for each year I sort the banks from smallest to largest (measuring size as the number of

\footnotetext{
${ }^{22}$ As this is not a panel specification, concerns about incidental variable bias do not apply to these estimates.

${ }^{23}$ HMDA data are not reported at the branch level and the lender unit is not defined for each individual branch of each bank. For example, Bank of America constitutes a lender.
} 
applications) and then drop the banks which collectively account for less than the first $0.5 \%$ of the total applications for the year. Dropping these small lenders significantly reduces the number of fixed effects without, however, affecting the representativeness of the sample in a meaningful way. One potential concern is that this rule-based pruning mechanism could induce sample-selection bias in the second stage, as small lenders sitting at the bottom of the distribution may arbitrarily exit and re-enter the data depending on their relative position in the activity rank. To alleviate such concerns, in the second stage I only include banks that either never exit or permanently exit the sample; re-entries are thus not included in the second stage.

Application-level covariates capture demand-side effects driven by borrower characteristics and loan attributes. I include standard proxies for risk such as the loan-to-income ratio, the natural logarithm of income, a dummy variable for minority applicants, ${ }^{24}$ as well as a categorical variable for lien status (first lien, junior lien, not secured by lien on real estate). Applications with a high loan to income ratio, low applicant income, from minority applicants, and for properties with junior liens are expected to face higher denial ratios. Following Loutskina and Strahan (2009) I include a dummy variable for loan amounts which exceed the conforming loan size threshold (jumbo loans). ${ }^{25}$ Loutskina and Strahan (2009) provide evidence of higher denial rates for non-conforming loans, due to their relative illiquidity, and this variable is expected to enter with a negative sign. For completeness, I also include a set of variables for the effect of which I do not have a strong prior but which could be relevant determinants of the credit decision. These are the natural logarithm of the loan amount, a categorical variable for applicant sex (male, female, not reported), and dummy variables for home-improvement, manufactured housing, and not-for-owner-occupied mortgage loans. ${ }^{26}$ Detailed definitions of each variable can be found in Table I.

\footnotetext{
${ }^{24}$ The minority dummy is constructed as in Munnell et al. (1996)

${ }^{25}$ The threshold is taken from Fannie Mae guidelines using the "general" threshold for 2008-2010.

${ }^{26}$ This parsimonious specification does not include securitization rates and other variables that may affect the lending decision. In a later section, however, I will show that the estimates obtained are robust to the inclusion of a much wider array of demandside variables, including securitization rates.
} 
Demand-side effects related to location are captured by the county-year dummies. For example, unemployment levels vary across counties and the county-year effects will capture the impact that the probability of an applicant exiting the labor market will have on the lending decision. County-year effects will also capture the combined effect of local lending opportunities, competition/market structure dynamics, ${ }^{27}$ house-price appreciation rates, crime rates, etc...; location-specific effects will thus not "contaminate" the estimated measure of supply-side lending propensity (the coefficients on lender-year effects).

\section{B. Second Stage}

The first stage extracts a measure of supply-side lending propensity that is free from demandside bias. The second stage estimates the impact of liquidity risk, arising from a high reliance on wholesale funding and high off-balance sheet exposure to lines of credit, on the supply of credit.

Consider first the model shown in Equation 3, where $\alpha_{i}, \kappa_{t}$ are lender and year fixed effects controlling for unobserved heterogeneity and aggregate macro effects respectively, $Z_{i t-1}$ is a vector that contains the two balance-sheet measures of liquidity risk, Controls $s_{i t-1}$ are additional controls and $D_{t=T}$ is a dummy variable which takes the value of 1 for year $\mathrm{T}$ and 0 otherwise. All financial variables are measured at end of previous year levels to reflect beginning of year conditions. The focus of this paper is on the coefficients of $Z_{i t-1}$.

$$
\begin{aligned}
L_{i t}= & \alpha_{i}+\kappa_{t}+\sum_{T=2004}^{2010} \gamma_{z t}\left(Z_{i t-1} \cdot D_{t=T}\right) \\
& +\sum_{T=2004}^{2010} \gamma_{c t}\left(\text { Control }_{i t-1} \cdot D_{t=T}\right)+\epsilon_{i t}
\end{aligned}
$$

The time-interacted coefficients allow for time-varying responses to liquidity risk and

\footnotetext{
${ }^{27}$ Addressing market structure, Dell'Ariccia and Marquez (2006) provide a model which connects the reduction in informational asymmetries between banks to a loosening of lending standards and subsequent loan portfolio deterioration. Dell'Ariccia, Igan and Laeven (2008) provide related empirical evidence by connecting the decrease in denial rates for mortgage loan applications to high housing price-appreciation rates, to market entry by large lenders, and to securitization rates in the US mortgage market during the period leading up to the crisis.
} 
thus capture the information provided by the timing of the liquidity shock; the timing of the financial crisis. Specifically, the estimates for $\gamma_{z t}$ trace the bank's credit supply response to high reliance on wholesale funding and high levels of unused lines of credit. For each of these two variables, however, the coefficients measure the net effect on credit supply of a set of mechanisms of which liquidity risk is but one, and thus also capture other normal correlations between the supply of credit and the levels of unused lines of credit and wholesale funding.

Key to identification is that the exogenous effect of liquidity risk on the supply of credit is not captured by the lenders' net response to their levels of exposure to core-deposit funding and unused lines of credit, but is rather inferred by the structural changes of those responses during periods of exogenous shocks to liquidity. The financial crisis brought about significant strains to liquidity for banks and their customers. To the extent that (i) the financial crisis and resulting strains were not anticipated by banks and (ii) the shocks to liquidity were primarily determined by the actions of actors outside the bank, we can assume these shocks to be exogenous to the bank's endogenous liquidity management operations. What these shocks contribute to identification, is to amplify the component of the lender's response function that corresponds to liquidity risk. It is this amplification effect that enables me to estimate the impact of liquidity risk on loan supply by estimating the structural breaks in the coefficients of the variables capturing exposure to liquidity risk.

Equation 4 describes the model used for identification in the second stage. It is econometrically identical to Equation 3, expressed now in a form that identifies liquidity effects in the supply of credit as the estimates of the coefficients $\delta_{z t}$, which for each coefficient $\gamma_{z t}$ (from Equation 3 above) track over time the structural breaks from the baseline year of 2004 to the 
period starting one year before and ending one year after the financial crisis (2006-2010). ${ }^{28}$

$$
\begin{aligned}
L_{i t}= & \alpha_{i}+\kappa_{t}+\gamma_{z} Z_{i t-1}+\sum_{T=2006}^{2010} \delta_{z t}\left(Z_{i t-1} \cdot D_{t=T}\right) \\
& +\gamma_{c} \text { Controls }_{i t-1}+\sum_{T=2006}^{2010} \delta_{c t}\left(\text { Controls }_{i t-1} \cdot D_{t=T}\right)+\epsilon_{i t}
\end{aligned}
$$

To estimate Equation 4 I use an OLS estimator. Financial variables are winsorized at the 1st and 99th percentiles to limit the impact of outliers. The use of an estimated dependent variable has no impact on point estimates other than inducing heteroskedasticity in the sample; the use of heteroskedasticity-robust standard errors addresses this concern. ${ }^{29}$ Errors are also clustered by lender to control for serial correlation in the error term.

I include unused lines of credit for real estate loans as well as core deposits, both scaled by total assets, to capture the effect of these two sources of liquidity risk on lending. I aggregate home equity lines of credit (HELOCs) and lines of credit for commercial real estate, land development and construction loans to create unused lines of credit for real estate loans. ${ }^{30}$ If we assume the constraint on liquid assets to be defined along asset category boundaries, a "forced" expansion of the size of the real estate loan portfolio is expected to exhibit its strongest effect on the supply of credit for the qualitatively similar mortgage loans that the first stage is estimated on. ${ }^{31}$ The coefficient for core deposits captures (when interpreted as relative to the missing component of wholesale funding) the effect of shocks coming from strains in the markets for wholesale funding during the crisis (repo, commercial paper, etc...). Given the mechanisms described in Section III., I expect the structural break in the coefficient of unused lines of credit to enter with a negative sign and the break in the coefficient of core

\footnotetext{
${ }^{28}$ The base year was chosen to be 2004 to ensure that we capture a clean picture of the pre-crisis model without being too close to the turning point.

${ }^{29}$ This is not the same as the case of an estimated regressor, which could affect the magnitude of the estimates.

${ }^{30}$ Activity coming from these two categories of lines of credit is likely to be correlated with mortgage loan activity at the aggregate level but not at the individual bank level, and thus creates no concern for identification. Furthermore, to the extent that a borrower's risk profile may be affected by the shocks that lead to drawdowns on credit lines by non-mortgage real estate customers, this correlation would be based on location and will be absorbed by the county-year effects in the first stage.

${ }^{31}$ Though exposure to unused lines of credit for non-real estate loans is less likely to affect credit for real estate loans, a measure of such exposure will be included in later robustness tests and shown to have no effect on the results.
} 
deposits to enter with a positive sign.

The vector of control variables includes the natural logarithm of assets, to control for size effects, as well as asset liquidity and capital adequacy ratios to control for the overall financial health of the lender. I also include the ratios to total illiquid assets of closed-end residential real estate loans, open-end residential real estate loans, and other real estate loans. These ratios capture the degree of lender specialization and also control for the degree of exposure to demand conditions in different segments of the real estate market. In the absence of loan portfolio ratios, the coefficient for unused lines of credit for real estate loans could be capturing the bank's overall exposure to sectors of the real estate market, since in general the levels of unused lines of credit in any particular loan category correlate strongly and positively with the presence of such loans on the bank's loan portfolio; the omission of these loan portfolio ratios could therefore give rise to omitted variable bias.

The direction of the effect for each of the control variables is not clear on theoretical grounds and I will thus present their coefficients without further discussion in the results section. With a particular focus on asset liquidity and capital adequacy one could argue that, being measures of financial health, they should enter estimation with positive structural breaks. The thinking normally employed is that since asset liquidity provides a buffer for negative shocks to liquidity and capital adequacy provides a similar buffer for negative shocks to capital, then the higher the buffer levels the more "immune" the bank is to such shocks, and the more lending it should engage in. Banks, however, may endogenously choose to build these buffers for reasons related to asset risk (as in Calomiris and Wilson (2004)), so high stocks of liquid assets and/or of capital could very well correlate negatively with lending propensity. 


\section{Regression Results}

In this section I discuss the results obtained from the estimation of the first stage of the model. I then present the results obtained in the second stage, which address the focal questions of the study.

\section{A. First Stage}

The estimated coefficients for borrower/loan characteristics are shown in Table IV. Consistent with Loutskina and Strahan (2009) I find that jumbo loans are less likely to be approved due to their relative illiquidity compared to conforming ones. ${ }^{32}$ Applications from minority applicants have a lower probability of approval. Loans under a junior lien and/or with no lien on a dwelling are less likely to be approved, reflecting the lower expected recovery rates in the case of a default. The negative sign for manufactured housing may reflect the fact that these housing structures are more prevalent in low-income, high risk households.

Regarding financial variables, the loan-to-income ratio enters with the expected negative sign, and the natural logarithm of income with the expected positive sign. The coefficient for the natural logarithm of loan amount is also positive, perhaps proxying for wealth effects of the applicant not completely captured by the income variable.

[Table IV about here]

Interpretation of these results beyond rough checks for sign consistency should be treated with caution. The controls aim at extracting the component of the lending decision that is due to borrower characteristics and loan attributes, and in doing so they could well be proxying for other demand-side unobservables. For similar reasons, the time-series variation

\footnotetext{
${ }^{32} \mathrm{~A}$ concern is that the reported loan amounts may be endogenously determined in order to fall below the jumbo threshold. This may induce bias on the coefficient for jumbo loans (and/or on the coefficient for loan amount) if unobserved borrower characteristics that are relevant for the approval decision also correlate with the loan amount. Such bias, however, should not affect the estimated lender-year effects which capture the supply of credit. In a robustness test, I re-estimated the first stage excluding all applications with loan amounts which fell between $95 \%$ and $100 \%$ of the jumbo threshold (approximately 1\%-2\% of all loan applications for each year). The estimated coefficients for lender-year effects remained unchanged, indicating that my identification strategy is robust to this potential source of bias.
} 
in their levels should also be interpreted with caution. The sole purpose of this first stage is to identify supply effects in lending propensity, through the coefficients on the lender-year dummies, and not to identify the causal effect of any of the application-level covariates.

\section{B. Second Stage}

With the supply-side measure of lending propensity now identified, I proceed with estimation of the second stage. As discusses earlier, the model includes a set of variables to control for the overall financial condition of the lender and to capture business cycle effects. The two variables capturing liquidity risk effects are Lines of credit for RE loans and Core-deposit funding; the estimated coefficients for other controls are provided for completeness with no extensive comments.

I first estimate the model shown in Equation 3, where coefficients are at annual levels. Figures VIII-IX plot the path through time of the coefficients for core-deposit funding and unused lines of credit for real estate loans respectively, with $95 \%$ confidence intervals drawn around the estimates. As discussed earlier, the exogenous effect of liquidity risk is captured by the structural changes of the coefficients over time; the levels of these coefficients should thus be compared to 2004 base levels, and not to 0 .

\section{[Figures VIII-IX about here]}

These two figures are key in displaying the central result of this paper, which is that the response to high levels of liquidity risk became progressively stronger as we entered the crisis, ${ }^{33}$ reached a peak in absolute value at the epicenter of the crisis in 2008, and then gradually returned to pre-crisis levels by 2010. Though it is possible that there are banks which experienced shocks to liquidity risk before or after the peak of the crisis in 2008 (after all, the precipitation in real estate prices started as early as 2006), the results suggest that the majority of the lenders responded to liquidity risk more aggressively during 2008.

\footnotetext{
${ }^{33}$ Moving in a negative direction for unused lines of credit and in a positive direction for core-deposit funding
} 
Figures X-XI now plot the structural breaks of the coefficients of the two variables that capture liquidity risk, compared to their pre-crisis 2004 levels. Table V displays the estimates of Equation 4, which directly identifies the structural breaks for all variables used in the second stage. The results indicate that high levels of unused lines of credit for real estate loans and low levels of reliance on stable core-deposit funding resulted in a decrease in lending propensity. The structural breaks for core-deposit funding are statistically significant for all years. The structural breaks for unused lines of credit for real estate loans are statistically significant only for 2007 and 2008.

[Figures X-XI about here]

[Table $\mathrm{V}$ about here]

In addition to the effects of liquidity risk, the results also show a negative effect on lending supply coming from exposure to real estate loans, with the effect becoming stronger in the final stages of the crisis. This could be the result of loan rebalancing operations but could also reflect actual and/or expected losses stemming from non-performing loans. With regards to open-end loans secured by real estate (loans resulting from drawdowns on home equity lines of credit for example), these loans have a time-lag in the revelation of strains on the borrower's repayment schedule. Even though the loans were properly accounted for on the balance sheets of lenders both during and after the crisis, significant portions of them were still within their draw period. This means that the recipients of these loans are providing only interest payments and have not moved to a full amortization schedule, the sudden commencement of which could result in a mass of writeoffs on these loans. ${ }^{34}$ This could be an explanation for the increase in the negative response to high holdings of open-end loans observed during the later stages of the crisis.

\footnotetext{
${ }^{34}$ Exposure to HELOCs is an ongoing concern for banks and repeatedly discussed, for example, in Citigroups's annual reports for 2009-2011
} 


\section{Large-small Bank Dichotomy}

The results discussed in the previous subsection identified the response of a heterogeneous set of lenders. The literature has traditionally studied differences in bank behavior by dividing lenders across the size dimension, as this is the dimension most likely to sort out the major differences in important unobservables between the two groups. ${ }^{35}$ Revisiting the tables of summary statistics for lenders, for example, one can clearly observe that smaller lenders are less exposed to the two sources of liquidity risk discussed in this paper.

To test for the presence of a large-small bank dichotomy in the results, I divide the sample into small (Assets $<\$ 1$ billion) and large (Assets $>\$ 1$ billion) lenders and study differences in the lending behavior of lenders in each sample. The $\$ 1$ billion threshold is in line with FRS reporting guidelines. The division is based on the average asset size of each lender in all the observations. The use of the average size ensures that I do not induce frequent exits and re-entries in the subsamples, due to lenders with asset size around the threshold switching between the two groups. ${ }^{36}$

To display some initial suggestive evidence of the presence of a dichotomy in the sample of lenders, Figure XII plots the time-path of the approval rates for the complete sample but also for the subsamples of small and large lenders. As expected, due to a size effect, the market average is driven primarily by the behavior of large lenders. ${ }^{37}$ Approval rates are noticeably lower for larger lenders. There is a monotonic, albeit small, drop in the approval rates of small lenders that seems to level off by 2010. The decline in approval rates is much sharper for large lenders, with significant declines experienced as early as 2006; a reversal of this trend takes place in 2009 and approval rates level off by 2010 .

[Figure XII about here]

\footnotetext{
${ }^{35}$ See Allen and Saunders (1986) for differences in the costs faced in the federal funds market, Kashyap and Stein (2000) for differences in the strength of the bank lending channel of transmission of monetary policy.

${ }^{36}$ The results, however, are in no way affected by using the actual asset size and re-categorizing the lenders every year as appropriate.

${ }^{37}$ Regarding estimation, each observation in the second stage is weighted equally so the second-stage results are not driven by the behavior of any one lender in particular.
} 
Approval rates, of course, capture the net effect of demand and supply factors. Though suggestive, the above evidence is thus not definitive proof of the presence of a dichotomy in the supply of mortgage credit. To test for differences in the effect of liquidity risk on the supply of mortgage credit for the two categories of lenders, I re-estimate the second stage separately for each sub-sample and the results are shown in panels (a) and (b) of Table VI for small and large lenders respectively.

[Table VI about here]

The results indicate that a large-small lender dichotomy is indeed present in the sample. Though the time-path of the coefficients for each lender category is consistent in shape and direction with the one obtained for the whole sample, it is now clear that the effects are much stronger for larger lenders compared to smaller ones. For smaller lenders, liquidity risk has a statistically significant effect only at the epicenter of the crisis in 2008. By contrast, for larger lenders the effect of core-deposit funding is statistically significant for all the years from 2006 to 2010, and the effect of unused lines of credit is statistically significant for all the years from 2006 to 2008. The size of the coefficients is also appreciably larger for larger lenders. These non-linearities could be driven by the higher levels of exposure of larger lenders to both wholesale funding and unused lines of credit.

The results also indicate differences in the timing of the effects between the two sources of liquidity risk. With reference to the estimates for larger lenders shown in panel (b) of Table VI, the contraction in the supply of mortgage credit due to high levels of exposure to unused lines of credit came to full effect as early as 2006, persisted through to 2008 but did not extend past that year. The effect of high exposure to wholesale funding reached its peak in 2008 but extended with diminished intensity past the end of the crisis in 2009 .

The estimates also suggest that the relative immunity to monetary policy tightening enjoyed by larger lenders, due to their comparative advantage in accessing the markets for 
wholesale funds, ${ }^{38}$ does not extend to funding shocks coming from the markets for wholesale funding, high exposure to which can quickly amplify such shocks.

The second-stage results shown in this section use far fewer observations than comparable studies relying just on call report data do. This is partly because the focus of this paper is on the subset of commercial banks which are mortgage lenders and largely because the lending decisions are only observed at the year level thus yielding just a single annual, instead of four quarterly, observations per lender per year. A consequence of this limitation is that I cannot track the crisis with the quarterly precision of other studies. Despite such limitations in the data, the estimation method fares well in tracking the different phases of the crisis with a reasonable degree of accuracy.

\section{Robustness Tests}

This section discusses a number of robustness tests. The results prove robust to the inclusion of additional demand-side observables, suggesting that the identification strategy does indeed robustly isolate supply-side from demand-side factors. Also, the results remain unaffected by the inclusion of a richer set of covariates in the second stage, hold under the secondstage specification employed by Cornett et al. (2011), and are robust to a number of other alternative specifications.

\section{A. Potential Omitted Variable Bias in the First Stage}

The first stage of the identification strategy does not aim at providing a complete model for the loan approval decision but rather seeks to isolate the component of that decision which is driven solely by supply-side mechanisms. The set of control variables used, though extensive, is not exhaustive and this may give rise to concerns pertaining to omitted variable bias. Omitted variables in the first stage can bias second stage results if and only if (i) the

\footnotetext{
38 as in Kashyap and Stein (2000)
} 
lender-year effects estimated in the first stage are "contaminated" by such omitted variable bias and (ii) the bias correlates with shocks to liquidity risk. ${ }^{39}$

More concretely, one potential challenge to the first-stage results is the absence of any control variables measured at the lender-county-year level. Such variables would control, for example, for different branches of a bank engaging in different lending practices in different locations. Such lender-specific yet spatially-heterogeneous responses could potentially bias the estimated coefficients for lender-year effects. Examples of variables capturing such interactions might include securitization rates, ${ }^{40}$ subprime mortgage activity, loan portfolio concentration, etc..., all measured at the lender-year-county level.

A second potential concern is that for some lenders the relevant market may not be the county but rather a more refined subdivision. ${ }^{41}$ Levels of unemployment, for example, may vary within a county. To the extent that some lenders, due to size or other strategic reasons, operate in distinct smaller areas, one might need to look to an additional level of geographic refinement, such as census-tract units, to capture location effects adequately; the concern is that failing to do so may introduce bias to the estimates of lender-year effects. ${ }^{42}$

My strategy for addressing the concerns expressed above, is to include additional observables in the first stage, re-estimate both the first and second stage, and show that (i) the new estimates of the lender-year effects are very highly correlated with the ones obtained from the original, parsimonious model thus suggesting that the original specification does robustly isolate supply-side from demand-side effects, and (ii) the second stage results remain virtually unchanged, indicating that whatever insignificant amount of bias might have carried through to the second stage in the parsimonious specification, does not correlate with

\footnotetext{
${ }^{39}$ Using second-stage regressors that are exogenous to first-stage unobservables is the standard method employed in the literature to deal with first-stage bias carrying through to the second stage. See, for example, the two-stage estimation strategy used in Kashyap and Stein (2000), Campello (2002), Cetorelli and Goldberg (forthcoming).

${ }^{40}$ Shown by Mian and Sufi (2009) to matter for the correct identification of lending drivers before the crisis. Keys et al. (2010) also show that the ease of securitization led to higher default rates for applicants with almost identical risk profiles.

${ }^{41}$ A similar concern is expressed in Mian and Sufi (2009)

${ }^{42}$ The first stage estimation drops a lot of small lenders who collectively account for less than $0.5 \%$ of total activity in the mortgage market. As these lenders are the ones most likely to operate within more refined definitions of location, this second potential source of bias is not likely to have a strong presence in the results.
} 
liquidity risk.

To address the first challenge discussed above, I include the rates at which originated loans were sold to a host of different types of intermediaries, local market shares, loan concentration rates, ${ }^{43}$ and a measure of the proportion of originated loans which were classified as subprime; ${ }^{44}$ all variables are measured at the lender-county-year level.

To address the second challenge I would ideally want to introduce census-tract-year effects, but doing so would increase the number of fixed effects by at least an order of magnitude and thus make the computational cost prohibitive. Instead, I include as additional controls local income as a percentage of MSA income and the percentage of minority population in the area, both measured at the census-tract level. Should within-county variation be a significant source of bias for the lender-year effects, the inclusion of these two variables should severely alter my first-stage estimates. Table I provides definitions for the additional control variables used in this test.

The model I estimate is shown in Equation 5, where $Y_{i j t}$ and $W_{k t}$ are vectors of variables containing the additional controls discussed above and measured at the lender-county-year and census-tract-year levels respectively.

$$
\operatorname{Pr}\left(A_{i j n t k}=1 \mid i, j, t, k, X_{n}, Y_{i j t}, W_{k t}\right)=\Lambda\left(L_{i t}+C_{j t}+\lambda_{t} X_{n}+\mu_{t} Y_{i j t}+\theta_{t} W_{k t}\right)
$$

The results show unambiguously that the first stage robustly identifies the supply-side component of the lending decision, even in the absence of theoretically significant demandside covariates in the original parsimonious specification. Table VII shows the first stage coefficients for the estimation using the richer set of covariates described above. As can be

\footnotetext{
${ }^{43}$ See Loutskina and Strahan (2011) for example, for empirical evidence indicating a negative relationship between lender geographic concentration and credit-rationing

${ }^{44}$ The HMDA dataset does not explicitly identify subprime applications. For originated loans, however, it does contain a rate-spread measure reported only when the borrowing rate exceeds a certain threshold when compared against the rate on a treasury security of comparable maturity. Including this variable in the first stage in raw form would force all of the potentially subprime applications to be dropped since where the spread is reported the loan is known to have originated (the dependent variable would always be 1 and the logit estimator would thus become unstable). Instead, to identify subprime activity, where the rate-spread is reported I create a "subprime" dummy variable which I average over all originations at the lender-county-year level and use this average as a control variable.
} 
seen in panel (a), for the most part the coefficients of the loan/borrower variables in the original parsimonious specification retain their signs and orders of magnitude with the observed changes. This indicates that the omission of demand-side characteristics in the original parsimonious specification may have only introduced a small bias on these coefficients, which should be expected since the coefficients may be proxying for a host of other demand-side unobservables. For completeness, the coefficients of the additional variables introduced in Equation 5 are shown in panel (b).

\section{[Table VII about here]}

More importantly as regards the impact on the estimated supply effects, Table VIII shows that the correlations between the estimated lender-year effects in the parsimonious and richer specifications are almost perfectly correlated for every year of the estimation. This is a clear indication that demand-side unobservables in the first stage are either (i) staying in the error term or (ii) slightly biasing demand-side coefficients while leaving the supply-side effects intact. The results in Table IX prove this point further by estimating the second stage (for the split sample) using the lender-year effects obtained from the first stage specification with the richer set of controls. The results in the second stage remain largely unaffected, with the coefficients for liquidity risk moving slightly in the direction of a more aggressive response.

\section{[Tables VIII-IX about here]}

\section{B. Potential Omitted Variable Bias in the Second Stage}

Concerns similar in spirit to the ones discussed for the first stage can also be raised for

the second stage of the model, as a number of factors which could potentially affect the lending decision were not controlled for in the original parsimonious second stage. Business cycle effects may be experienced differently in the cross section depending on the bank's 
loan portfolio choices that extend beyond the real estate market. The lending decision may depend on the aggregate demand for loans faced by the bank. Bank profitability or loan default rates may affect the lending decision. The key results in this paper could be biased if any of these omitted variables correlates with any or both of the two sources of liquidity risk.

To test for omitted variable bias in the second stage, I reestimate Equation 4 this time augmenting the set of controls to include the shares of consumer \& industrial loans as well as loans to individuals in the illiquid asset portfolio, ${ }^{45}$ total non-performing residential real estate loans over total assets, ${ }^{46}$ unused lines of credit for non-real estate loans, the return on average assets, and the total dollar value of mortgage loan demand scaled by the size of the residential real estate loans already on the balance sheet of the lender. The results for the small and large lender subsamples are shown in panels (a) and (b) of Table X, where for comparison purposes the parsimonious model was used in the first stage. The coefficients on unused lines of credit for real estate loans and on core-deposit funding are very close to the original ones reported in Table VI. For completeness, Table XI shows the second-stage results for a model that includes the augmented set of controls both in the first and the second stage.

[Tables X-XI about here]

\section{Alternative Specification Using an Interaction with the TED-spread}

An alternative specification that also aims at identifying the exogenous effect of liquidity risk on lending, is the one employed by Cornett et al. (2011), which I adapt to fit the framework of this paper. The specification is shown in Equation 6, where $T E D_{t}$ is the average TED

\footnotetext{
${ }^{45}$ Different loan categories correspond to activity in different sectors of the economy, and the composition of the bank's loan portfolio provides a more refined measure of the bank's exposure to the business cycle. The degree of exposure to each loan category can also affect loan liquidity and lending. Loutskina (2011) proposes an index for "bank loan portfolio" liquidity and shows that a loan portfolio with a high proportion of "easier" to securitize assets leads to lower levels of bank liquidity maintained by the bank and to increased lending activity.

${ }^{46}$ The results remain unchanged if I use total non-performing loans over total assets, or total non-performing residential real estate loans over total residential real estate loans.
} 
spread for year t: ${ }^{47}$

$$
\begin{aligned}
L_{i t}= & \alpha_{i}+\kappa_{t}+\gamma_{z} Z_{i t-1}+\gamma_{c} \text { Controls }_{i t-1} \\
& +\delta_{z}\left(Z_{i t-1} \cdot T E D_{t-1}\right)+\delta_{c}\left(\text { Controls }_{i t-1} \cdot T E D_{t-1}\right)+\epsilon_{i t}
\end{aligned}
$$

The TED spread measures funding strains in the banking sector, and as an aggregate measure is understood to change exogenously to an individual lender's financial condition. The effect of liquidity risk can thus be identified by interacting each of the variables capturing the two sources of liquidity risk with the TED spread. One limitation of my dataset is that I only observe lending decisions at an annual frequency, and by necessity I therefore use the average TED spread over each year. Figure XIII shows monthly and annual averages for the TED spread starting in 2000:

[Figure XIII about here]

This plot demonstrates the "mechanics" of the identification strategy under this specification. Observing the time-series variation at the annual level, one can see the TED spread widening significantly, first in 2007 and then even further in 2008. With lending-propensity measured at the annual level, the interaction term will thus act as a dummy of sorts - a weighting mechanism- indicating whether the response to high levels of liquidity risk was disproportionately higher in 2007-2008 compared to the other periods. This specification can thus be seen as adding the identification restriction that the time-path of the estimated coefficients of the model shown in Equation 4 should follow the time-series variation in the TED spread.

I estimate the specification shown in Equation 6 using the additional sets of controls discussed in Subsections 1 and 2 above. The results, shown in Table XII, are consistent with those obtained using the structural changes approach of Equation 4. I obtain statistically

\footnotetext{
${ }^{47}$ The TED spread is defined as the difference in interest rate between 3-month LIBOR and the 3-month Treasury bill.
} 
significant coefficients of the same sign and order of magnitude as before, ${ }^{48}$ with the statistical significance for core deposits lost for smaller lenders. ${ }^{49}$

\section{[Table XII about here]}

The TED spread captures funding strains in the banking sector and thus tracks shocks in the markets for wholesale funds fairly accurately. These markets experienced significant strains in 2007-2008, and to the extent that some of the banks' customers experienced strains on their own liquidity at time-periods other than 2007-2008, the interaction term may not capture the effect of liquidity risk stemming from drawdowns on lines of credit accurately over time. For example, real estate developers drawing down on lines of credit for commercial real estate loans may have been induced to do so by exogenous (unanticipated) shocks to their profitability. Unable to fund new projects from profits, they draw down their credit lines thus inducing negative shocks to the bank's liquidity. If the levels of such drawdowns are in excess of the normal levels anticipated and provisioned for by the banks' liquidity management operations, then they will impose exogenous (unanticipated) shocks to bank liquidity. If, furthermore, such shocks took place earlier than 2007, then the TED spread interaction term will not adequately capture the full effect of exogenous shocks to liquidity from line of credit drawdowns on lending propensity. ${ }^{50}$ The summary statistics presented in Section V. showed that drawdowns on lines of credit did lead the stresses in the markets for wholesale funding. In addition, the plot of the Case-Shiller index shown in Figure XIV, suggests that shocks to the real estate market might have been in place as early as 2006, which is when housing prices first started showing signs of the impending decline.

\footnotetext{
${ }^{48}$ Order of magnitude comparisons are in general not appropriate when comparing an interaction with a dummy variable (structural breaks model) to an interaction with a continuous variable (TED spread model), but given the earlier discussion on the workings of the TED spread interaction, and the fact that the TED spread in its peak years is of the order of magnitude of 1-1.5 units of measurement (percentage points) a simple sanity-check type comparison of the coefficients can be safely performed here.

${ }^{49}$ In an unreported regression, I also show that the results hold if observations for 2004 are excluded from the sample.

${ }^{50}$ Even in the presence of fully functional markets for wholesale funds (low TED spread) exogenous shocks to liquidity from drawdowns on lines of credit may still induce rationing, assuming that the lender already operates on the margin of a regulatory (or market) liquidity constraint, which would make raising additional funds in the markets for wholesale funding undesirable.
} 
[Figure XIV about here]

\section{Unobserved Applicant Exits}

Tighter bank lending standards may induce unobserved exits. For example, a rise in downpayment requirements may force applicants who understand that they are less likely to be approved for a loan (under the new more stringent standards) to exit the market for mortgage loans. These "would be" applicants would thus not be documented in HMDA data, and conditioning the estimates on the number of loan applications would ignore this additional source of supply-driven contraction.

For most applicants such tightening of lending policies becomes evident after an application for a mortgage loan is filed, and they thus do not exit the market before their application is registered in HMDA. Assuming, however, that supply-driven policies do lead applicants to preemptively exit the market before being registered in HMDA, a troubling scenario would be one in which the degree of tightening of lending standards that leads to such exits correlates with the level of exposure to liquidity risk. If that was the case, however, then the net effect would be to bias the estimates of the impact of liquidity risk on credit in a positive direction (positive bias for unused lines of credit and negative bias for core-deposit funding). Under such a scenario, the estimates would be lower bounds in magnitude to the true effects. Therefore, the results would have been even stronger had this source of bias not been present.

\section{E. Value of Intangibles for Core Deposits}

The previous robustness tests established that the effect captured by core deposits is due to the level of core-deposit funding and not due to a correlation with some unobservable demand or lender characteristic. Still, one could argue that the observed effect is reflecting more than liquidity risk. For example, it may be related to other core-deposit intangibles, 
such as lower funding costs. Calomiris and Nissim (2012), however, show that the value of such intangibles declines in a low interest rate environment, such as the one prevalent during the years of the crisis. ${ }^{51}$ Therefore, if it was indeed the case that the coefficient for core-deposit funding was also capturing other core-deposit intangibles, then the presence of this component which decreases in value during the crisis, suggests that the effect of liquidity risk would be even stronger than estimated.

\section{F. Other Robustness Tests}

In other tests not reported here, the results proved robust to the use of alternative definitions of asset liquidity excluding agency obligations or including all security holdings except for mortgage backed and asset backed securities, to the use of alternative definitions for core deposit funding including insured brokered deposits and/or uninsured brokered deposits, to the use of a risk-weighted measure of capital adequacy, to the inclusion of the ratios of private and agency mortgage backed securities as well as the ratio of asset backed securities to illiquid assets in the set of controls, and to the use of September call report data to ameliorate the effects of end-of-year window-dressing operations on the bank's balance sheet.

\section{Economic Significance}

In this section I estimate the economic impact of liquidity risk on credit origination in the mortgage market. In a first counterfactual, I estimate the increase in the dollar volume of originations that would have occurred had the banks not adjusted their credit supply in response to liquidity risk experienced during 2007-2009. In a second counterfactual, I also estimate the increase in the dollar volume of originations that would have resulted from the banks adjusting their credit supply in response to liquidity risk, but operating during the

\footnotetext{
${ }^{51}$ Although in Calomiris and Nissim (2012) value creation extends into 2008, as argued by the authors, this is likely due to the use of a market-based measure of value creation. Commercial banks, however, are likely to internalize the effects of the drop in interest rates on core-deposit value creation with a much shorter lag than markets do.
} 
crisis with levels of liquidity risk reduced by one standard deviation.

The estimates rely on the use of two different models (i) the model with flexible structural breaks (Equation 4) and (ii) the model with the TED spread interactions (Equation 6). I use the richer set of control variables described in the previous section in both the first and second stages of estimation. ${ }^{52}$ The models are estimated on a split sample for small and large banks, allowing for the use of a different set of coefficients and standard deviations for each group.

The first step in this process is to compute baseline values for the expected level of mortgage originations for each year predicted by the model. In particular, for each year I first use the logit model of the approval decision to compute the predicted probability of approval for each loan. I then multiply the predicted probability of approval by the loan amount and sum over all loans to get a base level for the expected volume of mortgage originations predicted by the first stage model for each year. Loans that have been approved but not taken, and hence not originated, are excluded from the sample. ${ }^{53}$ The results are shown in Table XIII, where we can see that the first-stage model predicts total originations reasonably precisely for each year.

[Table XIII about here]

To compute the change in mortgage originations that would have resulted had banks not adjusted their credit responses to high levels of liquidity risk in 2007-2009, I proceed in two steps. First, I use the second-stage model to estimate the increase in supply-driven lending propensity that would have resulted had the banks not adjusted their responses to each (or both) sources of liquidity risk. ${ }^{54}$ I then substitute these countefactual lending propensities

\footnotetext{
${ }^{52}$ As the estimated coefficients are very similar in magnitude in all specifications, the results remain unchanged if the original parsimonious specifications are used instead.

${ }^{53}$ The results remain qualitatively unchanged if I keep approved but not taken loans in the sample and thus run the counterfactual analysis on loan approvals rather than loan originations. The only difference is that the predicted base volume is now even closer to the actual volume of approved loans in the data (within $\$ 1$ billion - $\$ 2$ billion for any year). This is to be expected since the first stage uses approval rather than origination as the decision variable.

${ }^{54}$ Because of the non-linearity of the first stage, the combined effect of removing both sources of liquidity risk simultaneously is not equal to the sum of the effects of removing each source independently.
} 
back into the first-stage model to compute the increase in the probability of approval for each loan, and aggregate over all loans to get the expected volume of originations.

For the model with structural breaks (Equation 4), to compute the independent effect of each source of liquidity risk on lending propensity, I set the corresponding interaction term to zero for each year; to compute the combined effect, I set both interaction terms to zero. For each source of liquidity risk, the resulting increase in the lender-year effect (the dependent variable in the second stage) is equal to the product of the level of exposure to the risk times the previously estimated structural change of the coefficient for that source of risk; to get the combined increase, I add the two adjustments. For the model with the TED spread interactions (Equation 6), I reduce the TED spread down to its 2004 level. The corresponding individual adjustments involve increasing the lender-year effects by the triple product of the previously estimated coefficient for the TED spread interaction term, the level of exposure to the source of liquidity risk, and the change in the TED spread from its 2004 level.

The final step is a straightforward substitution of the adjusted lender-year effects back into the first stage model to arrive at the expected adjusted dollar volume of originations. I repeat this exercise separately for each of the years of the financial crisis of 2007-2009. The level of detail in the HMDA dataset allows me to use demand covariates at their actual values for each individual loan application. The non-linearity of the first stage model does not impose constant marginal probabilities, but rather more realistically allows for the impact of changes in credit supply to vary with the baseline position of each application along the logit curve. For example, for the same increase in the level of a lender-year effect, loan applications with an already high baseline probability of approval will experience a smaller increase in the probability of approval than ones with a lower baseline probability of approval.

Table XIV shows the estimated increase in the volume of originations in \$billion (panel a) and also as a percentage of the total base volume for each year (panel b). Each panel 
shows separate estimates for scenaria in which the sources of liquidity risk are removed independently or simultaneously. The first three columns show estimates using the model with flexible structural breaks and the remaining three columns show estimates using the model with the TED spread interactions.

\section{[Table XIV about here]}

Liquidity risk had the largest impact on the dollar volume of mortgage originations in 2007, a result driven by the larger size of the mortgage market during that year. The two models estimate the combined effect for 2007 to be between $\$ 20.9$ billion and $\$ 31.9$ billion. As a percentage of the dollar volume of originations, the largest effect is observed at the peak of the crisis in 2008. For that year, the two models estimate the percentage effect to be between $8.1 \%$ and $9.9 \%$.

Had the banks' credit operations not adjusted their response levels to liquidity risk in 2007-2009, the total combined increase in mortgage originations would have been between $\$ 41.5$ billion and $\$ 61.9$ billion, or $5.2 \%-7.8 \%$ of total mortgage originations during that period. Although the estimates indicate that for 2007-2009 the two sources of liquidity risk generated contractions of the same order of magnitude, funding stresses in the markets for wholesale funding have contributed more to the overall effect.

In a second counterfactual, I estimate the increase in mortgage originations that would have resulted had the banks adjusted their responses to liquidity risk, but operated during 2007-2009 with a one standard deviation reduction in their levels of liquidity risk; that is, increasing the degree of core-deposit funding and decreasing the exposure to unused lines of credit for real estate loans. ${ }^{55}$ In this counterfactual, banks' credit supply responds to liquidity risk but the levels of exposure to liquidity risk are lower.

For the model with structural breaks, for each source of liquidity risk, the adjustment involves an increase of the lender-year effect equal to the product of the structural break

\footnotetext{
${ }^{55}$ The changes in the levels of liquidity risk are censored where needed to ensure that (i) the adjusted values of unused lines of credit do not fall below 0 and (ii) the sum of the equity capital and adjusted core deposit asset ratio does not exceed 1.
} 
of the coefficient for liquidity risk times the change in exposure to liquidity risk. For the model with the TED spread interactions, the adjustment results in an increase equal to the triple product of the coefficient of the TED spread interaction term, the TED spread, and the change in exposure to liquidity risk. Table XV shows the resulting estimates.

[Table XV about here]

The estimates indicate that for the period 2007-2009 as a whole, the total combined increase in mortgage originations would have been between $\$ 24.2$ billion and $\$ 27.4$ billion, or $3.1 \%-3.5 \%$ of total originations for that period. The largest increase in the dollar volume of originations would have occurred in 2007 ( $\$ 12.5$ billion - $\$ 15$ billion) and the largest percentage increase would have occurred in 2008 (4.5\%-4.6\%).

Consistent with findings reported earlier in the paper, the estimates obtained using the model with flexible structural breaks are comparable to the ones obtained using the model with the TED spread interactions. As discussed earlier, this study does not fully capture the aggregate effects of liquidity risk on lending; these numbers are thus conservative estimates of the true effect.

\section{Conclusion}

The financial crisis of 2007-2009 offers a unique opportunity to refine our understanding of the mechanisms through which liquidity risk materializes on the balance sheets of banks and contributes to the contraction of credit during a crisis. In this paper I use micro-level data on mortgage loan applications to estimate the extent to which liquidity risk contributed to the collapse in the supply of mortgage credit during the recent crisis. The data allow me

to identify shifts in loan supply at the actual point of the approval decision for granting a mortgage loan, and purge the lending decision from demand-side effects with a greater degree of precision than previous studies. 
The results suggest that liquidity risk was an important driver behind the credit crunch. In particular, banks with higher levels of unused lines of credit for real estate loans and lower levels of core-deposit funding, tightened their lending standards more than banks that were less exposed to these sources of liquidity risk. A large-small bank dichotomy is present in the results, where larger lenders are shown to have responded more aggressively to higher levels of exposure to liquidity risk. The identification strategy also allows me to track the impact of liquidity risk through time and show that the effect from exposure to credit lines preceded the effect from dependence on wholesale funding. The results prove robust to the inclusion of a much richer array of covariates, both in the first and second stages, hold under the second-stage specification employed by Cornett et al (2011), and are robust to a number of alternative specifications.

In counterfactual analysis, I estimate that the total contraction in mortgage lending due to the increased responsiveness to liquidity risk during 2007-2009 was $\$ 41.5$ billion - $\$ 61.9$ billion, or $5.2 \%-7.8 \%$ of total mortgage originations during that period. I also estimate that had banks operated during the crisis of 2007-2009 with their levels of exposure to each source of liquidity risk reduced by one standard deviation, this would have resulted in a combined increase in the dollar volume of mortgage originations of $\$ 24.2$ billion - $\$ 27.4$ billion $(3.1 \%$ $3.5 \%)$.

Access to the markets for wholesale funds provides the funding margin which allows lenders to rapidly respond to profitable loan opportunities as those arise. Credit lines provide a similar margin of liquidity support for their recipients, which allows them to take on projects in the face of uncertainty in their future liquidity position. Excessive use of these margins can, however, lead to high levels of exposure to liquidity risk and this paper showed that such exposure can in turn result in a severe contraction of credit supply, in the event of actual or anticipated disruptions in the markets for wholesale funds and funding illiquidity pressures on the holders of credit lines. An interesting research question would be the design 
of optimal funding-mix rules for the lender, which take into account both the upside and the downside of exposure to liquidity risk over the full financial cycle. This question can also be approached from the standpoint of a regulator, where the two competing objectives would be the facilitation of credit-provision and the safeguarding of the economy against a recurrence of the contraction of credit experienced during the financial crisis of 2007-2009. 


\section{References}

Adrian, Tobias, and Hyun Song Shin. 2009. "Money, Liquidity, and Monetary Policy." American Economic Review, 99(2): 600-605.

Aiyar, Shekhar, Charles W. Calomiris, and Tomasz Wieladek. 2012. "Does MacroPru Leak? Evidence from a UK Policy Experiment." NBER Working Paper 17822, February.

Allen, Linda, and Anthony Saunders. 1986. "The large-small bank dichotomy in the federal funds market." Journal of Banking 6 Finance, 10(2): 219-230.

Berger, Allen N., and Christa H. S. Bouwman. 2009. "Bank Liquidity Creation." The Review of Financial Studies, 22(9): 3779-3837.

Bernanke, Ben S., and Alan S. Blinder. 1992. "The Federal Funds Rate and the Channels of Monetary Transmission." American Economic Review, 82(4): 901-921.

Calomiris, Charles W. 1989. "The motivations for loan commitments backing commercial paper: A comment on 'commercial paper, bank reserve requirements, and the informational role of loan commitments." Journal of Banking and Finance, 13(2): 271-277.

Calomiris, Charles W., and Berry Wilson. 2004. "Bank Capital and Portfolio Management: The 1930s Capital Crunch and the Scramble to Shed Risk." Journal of Business, $77(3): 421-456$.

Calomiris, Charles W., and Doron Nissim. 2012. "Crisis-Related Shifts in the Market Valuation of Banking Activities." NBER Working Paper No. 17868, February.

Campello, Murillo. 2002. "Internal capital markets in financial conglomerates: Evidence from small bank responses to monetary policy." Journal of Finance, 57(6): 2773-2805. 
Campello, Murillo, Erasmo Giambona, John R. Graham, and Campbell R. Harvey. 2011. "Liquidity Management and Corporate Investment During a Financial Crisis." Review of Financial Studies, 24(6): 1944-1979.

Cetorelli, Nicola, and Linda Goldberg. forthcoming. "Banking Globalization and Monetary Transmission." Journal of Finance.

Cornett, Marcia Millon, Jamie John McNutt, Philip E. Strahan, and Hassan Tehranian. 2011. "Liquidity risk management and credit supply in the financial crisis." Journal of Financial Economics, 101(2): 297-312.

Dell'Ariccia, Giovanni, and Robert Marquez. 2006. "Lending Booms and Lending Standards." Journal of Finance, 61(5): 2511-2546.

Dell'Ariccia, Giovanni, Deniz Igan, and Luc A. Laeven. 2008. "Credit Booms and Lending Standards: Evidence from the Subprime Mortgage Market." IMF Working Paper, No. $08 / 106$.

Demyanyk, Yuliya, and Otto Van Hemert. 2008. "Understanding the subprime mortgage crisis." Federal Reserve Bank of St. Louis Supervisory Policy Analysis Working Papers. Available at SSRN: http://ssrn.com/abstract=1020396 or http://dx.doi.org/10.2139/ssrn.1020396.

Gatev, Evan, Til Schuermann, and Philip E. Strahan. 2009. "Managing Bank Liquidity Risk: How Deposit-Loan Synergies Vary with Market Conditions." Review of Financial Studies, 22(3): 995-1020.

Gatev, Evan, Til Schuermann, and Philip Strahan. 2007. "How Do Banks Manage Liquidity Risk? Evidence from the Equity and Deposit Markets in the Fall of 1998." In The Risks of Financial Institutions. 105-132. National Bureau of Economic Research, Inc. 
Gorton, Gary, and Andrew Metrick. 2012. "Securitized banking and the run on repo." Journal of Financial Economics, 104(3): 425-451.

Holmstrom, Bengt, and Jean Tirole. 2000. "Liquidity and Risk Management." Journal of Money, Credit and Banking, 32(3)(3): 295-319.

Ivashina, Victoria, and David S. Scharfstein. 2010. "Bank Lending During the Financial Crisis of 2008." Journal of Financial Economics, 97(3): 319-338.

Jimenez, Gabriel, Steven Ongena, Jose-Luis Peydro, and Jesus Saurina. 2012. "Credit Supply and Monetary Policy: Identifying the Bank Balance-Sheet Channel with Loan Applications." American Economic Review, 102(5): 2301-26.

Kashyap, Anil K, and Jeremy C. Stein. 2000. "What Do a Million Observations on Banks Say about the Transmission of Monetary Policy?" American Economic Review, 90(3): 407-428.

Kashyap, Anil K, Raghuram Rajan, and Jeremy C. Stein. 2002. "Banks as liquidity providers: An explanation for the coexistence of lending and deposit-taking." Journal of Finance, 57(1): 33-73.

Keys, Benjamin J., Tanmoy K. Mukherjee, Amit Seru, and Vikrant Vig. 2010. "Did Securitization Lead to Lax Screening? Evidence from Subprime Loans." Quarterly Journal of Economics, 125.

Khwaja, Asim Ijaz, and Atif Mian. 2008. "Tracing the impact of bank liquidity shocks." American Economic Review, 98(4): 1413-1442.

Loutskina, Elena. 2011. "The role of securitization in bank liquidity and funding management." Journal of Financial Economics, 100(3): 663-684.

Loutskina, Elena, and Philip E. Strahan. 2009. "Securitization and the declining impact of bank financial." Journal of Finance, 64(2): 861-922. 
Loutskina, Elena, and Philip E. Strahan. 2011. "Informed and Uninformed Investment in Housing: The Downside of Diversification." Review of Financial Studies, 24(5): 14471480.

Mian, Atif Rehman, and Amir Sufi. 2009. "The Consequences of Mortgage Credit Expansion: Evidence from the U.S. Mortgage Default Crisis." The Quarterly Journal of Economics, 124(4): 1449-1496.

Munnell, Alicia, Geoffery M.B. Tootell, Lynn E. Browne, and James McEneaney. 1996. "Mortgage lending in Boston: Interpreting the HMDA data." American Economic Review, 86(1): 25-23.

Paravisini, Daniel. 2008. "Local Bank Financial Constraints and Firm Access to External Finance." Journal of Finance, 63(5): 2161-2193.

Peek, Joe, and Eric Rosengren. 1997. "The International Transmission of Financial Shocks: The Case of Japan." The American Economic Review, 87(4): 495-505.

Peek, Joe, and Eric Rosengren. 2000. "Collateral damage: Effects of the Japanese bank crisis on real activity in the United States." The American Economic Review, 90(1): 30-45.

Puri, Manju, Jrg Rocholl, and Sascha Steffen. 2011. "Global retail lending in the aftermath of the US financial crisis: Distinguishing between supply and demand effects." Journal of Financial Economics, 100(3): 556-578.

Ratnovski, Lev, and Rocco Huang. 2009. "Why are Canadian Banks More Resilient?" IMF Working Paper, 1-19.

Schwarz, Krista. 2010. "Mind the Gap: Disentangling Credit and Liquidity in Risk Spreads." Available at SSRN: http://ssrn.com/abstract=1486240 or http://dx.doi.org/10.2139/ssrn.1486240. 
Table I

Definitions

\begin{tabular}{|c|c|c|}
\hline VARIABLE & SOURCE & DEFINITION \\
\hline \multicolumn{3}{|c|}{ Measured at the application level } \\
\hline Minority & HMDA & Applicant is a minority \\
\hline Female & HMDA & Applicant is female \\
\hline Sex Not Reported & HMDA & Applicant's sex is not reported \\
\hline Entity & HMDA & Applicant is an entity \\
\hline log Income & HMDA & Natural logarithm of applicant's income \\
\hline $\log$ Amount & HMDA & Natural logarithm of the loan amount \\
\hline Loan to Income Ratio & HMDA & Loan amount divided by income \\
\hline Manufactured & HMDA & Loan is for manufactured housing \\
\hline Improvement & HMDA & Loan is for house improvement \\
\hline Jumbo & HMDA & Loan falls in the jumbo category \\
\hline Second lien & HMDA & Loan is secured by junior lien \\
\hline No lien & HMDA & Loan not secured by lien on dwelling \\
\hline \multicolumn{3}{|c|}{ Measured at the lender-county-year level } \\
\hline LCPctSold & HMDA & Number of same year securitizations divided by originations \\
\hline LCPctSoldGSE & HMDA & As above, sold to a Government Sponsored Enterprise \\
\hline LCPctSoldSec & HMDA & As above, sold for a private securitization \\
\hline LCPctSoldAffiliate & HMDA & As above, sold to a bank affiliate \\
\hline LCPctSoldCommercial & HMDA & As above, sold to a commercial bank \\
\hline LCPctSoldOther & HMDA & As above, sold to other institution \\
\hline LCPctSoldMortgage & HMDA & As above, sold to mortgage company \\
\hline BLPortfolioConcentration & HMDA & $\begin{array}{l}\text { Applications in ijt divided by total applications to lender at } \\
\text { year } t\end{array}$ \\
\hline BL Market Share & HMDA & $\begin{array}{l}\text { Lender number of applications in jt, divided by total number } \\
\text { of applications to all lenders in jt }\end{array}$ \\
\hline BLPctSubprime & HMDA & Total subprime in ijt divided by total originations in ijt \\
\hline \multicolumn{3}{|c|}{ Measured at the census-tract-year level } \\
\hline Tract income & HMDA & Average income as percentage of MSA income \\
\hline Tract Pct Minority & HMDA & Percent of population who are minority \\
\hline \multicolumn{3}{|c|}{ Measured at the lender-year level } \\
\hline $\log$ Assets & Call Report & Natural logarithm of assets \\
\hline Tier1 leverage ratio & Call Report & Tier 1 capital, divided by assets \\
\hline ROAA & Call Report & Net income divided by average assets \\
\hline Liquid assets & Call Report & $\begin{array}{l}\text { The sum of cash, federal funds sold, securities purchased un- } \\
\text { der agreement to resell, treasury securities, and agency obli- } \\
\text { gations }\end{array}$ \\
\hline Illiquid Assets & Call Report & Total assets - Liquid assets \\
\hline Closed-end RE loans & & $\begin{array}{l}\text { Closed-end revolving loans secured by } 1-4 \text { family residential } \\
\text { properties divided by illiquid assets }\end{array}$ \\
\hline Open-end RE loans & Call Report & $\begin{array}{l}\text { Open-end loans secured by 1-4 family residential properties } \\
\text { divided by illiquid assets }\end{array}$ \\
\hline Other RE loans & Call Report & All other loans secured by real estate divided by illiquid assets \\
\hline Commercial and industrial & Call Report & Commercial and industrial loans divided by illiquid assets \\
\hline Loans to individuals & Call Report & Loans to individuals divided by illiquid assets \\
\hline Default rate for RRE loans & Call Report & $\begin{array}{l}\text { Loans secured by } 1-4 \text { family residential properties over } 90 \\
\text { days late plus loans not accruing divided by total assets }\end{array}$ \\
\hline Core-deposit funding & Call Report & $\begin{array}{l}\text { The sum of demand deposits, MMDA and other savings de- } \\
\text { posits, NOW, ATS and other interest-bearing transaction ac- } \\
\text { counts, and insured time deposits scaled by total assets }\end{array}$ \\
\hline Lines of credit for non-RE loans & Call Report & Unused lines of credit for non-real estate loans \\
\hline Lines of credit for RE loans & Call Report & Unused lines of credit for real estate loans \\
\hline RRE loan demand & $\begin{array}{l}\text { HMDA/ Call } \\
\text { Report }\end{array}$ & $\begin{array}{l}\text { Total dollar volume of HMDA applications to lender divided } \\
\text { by book value of stock of residential real estate loans of the } \\
\text { lender }\end{array}$ \\
\hline
\end{tabular}


Table II

Summary statistics for loan/borrower characteristics 2004, 2006-2010

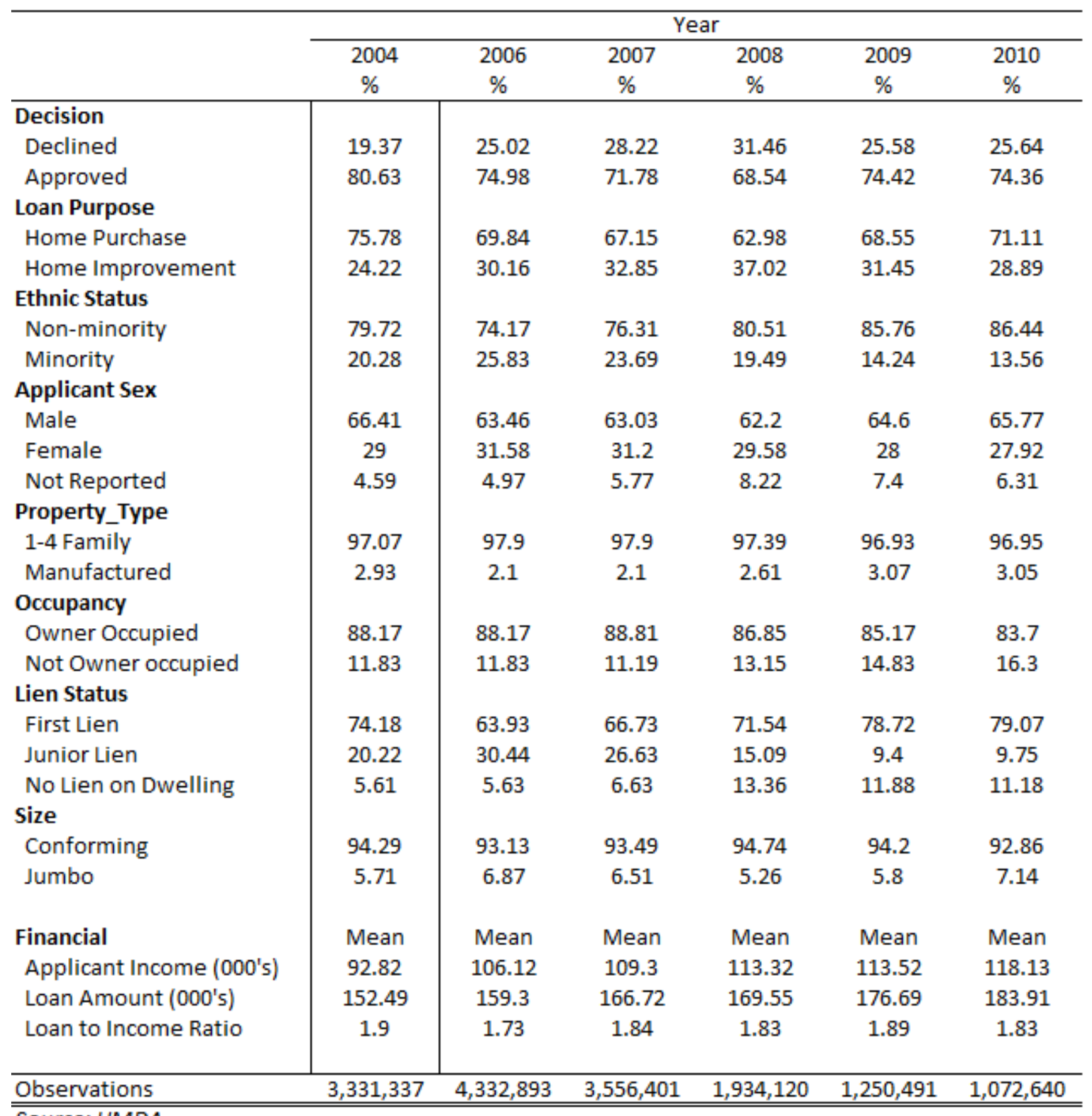

Source: HMDA

Notes: The table displays summary statistics for borrower characteristics and loan attributes for mortgage loan applications to commercial banks for the years 2004, 2006-2010. 
Table III

Summary statistics for bank characteristics 2004, 2006-2010

\begin{tabular}{|c|c|c|c|c|c|c|c|c|c|c|c|c|}
\hline \multirow{2}{*}{$\begin{array}{l}\text { SIZE } \\
\text { YEAR }\end{array}$} & \multicolumn{6}{|c|}{ SMALL (ASSETS $<\$ 1$ bil) } & \multicolumn{6}{|c|}{ LARGE(Assets >\$1 bil) } \\
\hline & Q4 2003 & Q4 2005 & Q4 2006 & Q4 2007 & Q4 2008 & Q4 2009 & Q4 2003 & Q4 2005 & Q4 2006 & Q4 2007 & Q4 2008 & Q4 2009 \\
\hline log Assets & $\begin{array}{c}14.34 \\
(7.998)\end{array}$ & $\begin{array}{c}14.43 \\
(7.431)\end{array}$ & $\begin{array}{c}14.61 \\
(7.402)\end{array}$ & $\begin{array}{c}14.53 \\
(7.082)\end{array}$ & $\begin{array}{c}14.56 \\
(7.323)\end{array}$ & $\begin{array}{c}14.49 \\
(6.963)\end{array}$ & $\begin{array}{c}38.30 \\
(54.06)\end{array}$ & $\begin{array}{c}36.54 \\
(51.30)\end{array}$ & $\begin{array}{c}37.10 \\
(55.60)\end{array}$ & $\begin{array}{c}37.01 \\
(58.00)\end{array}$ & $\begin{array}{c}35.40 \\
(58.17)\end{array}$ & $\begin{array}{c}34.36 \\
(53.34)\end{array}$ \\
\hline Tier 1 leverage ratio & $\begin{array}{c}0.0961 \\
(0.0261)\end{array}$ & $\begin{array}{c}0.0973 \\
(0.0258)\end{array}$ & $\begin{array}{c}0.0987 \\
(0.0269)\end{array}$ & $\begin{array}{c}0.0986 \\
(0.0262)\end{array}$ & $\begin{array}{c}0.0961 \\
(0.0257)\end{array}$ & $\begin{array}{c}0.0948 \\
(0.0255)\end{array}$ & $\begin{array}{c}0.0839 \\
(0.0183)\end{array}$ & $\begin{array}{c}0.0857 \\
(0.0189)\end{array}$ & $\begin{array}{c}0.0864 \\
(0.0176)\end{array}$ & $\begin{array}{c}0.0859 \\
(0.0178)\end{array}$ & $\begin{array}{c}0.0855 \\
(0.0175)\end{array}$ & $\begin{array}{c}0.0858 \\
(0.0181)\end{array}$ \\
\hline Asset liquidity & $\begin{array}{c}0.167 \\
(0.106)\end{array}$ & $\begin{array}{c}0.155 \\
(0.0971)\end{array}$ & $\begin{array}{c}0.151 \\
(0.0953)\end{array}$ & $\begin{array}{c}0.133 \\
(0.0915)\end{array}$ & $\begin{array}{c}0.116 \\
(0.0867)\end{array}$ & $\begin{array}{c}0.138 \\
(0.0858)\end{array}$ & $\begin{array}{c}0.136 \\
(0.0929)\end{array}$ & $\begin{array}{c}0.125 \\
(0.0842)\end{array}$ & $\begin{array}{c}0.119 \\
(0.0825)\end{array}$ & $\begin{array}{c}0.0986 \\
(0.0743)\end{array}$ & $\begin{array}{c}0.0839 \\
(0.0698)\end{array}$ & $\begin{array}{c}0.112 \\
(0.0772)\end{array}$ \\
\hline ROAA & $\left|\begin{array}{c}0.0110 \\
(0.00615)\end{array}\right|$ & $\begin{array}{c}0.0111 \\
(0.00635)\end{array}$ & $\begin{array}{c}0.0110 \\
(0.00602)\end{array}$ & $\begin{array}{c}0.0101 \\
(0.00797)\end{array}$ & $\begin{array}{c}0.00572 \\
(0.00967)\end{array}$ & $\begin{array}{l}0.00372 \\
(0.0113)\end{array}$ & $\begin{array}{c}0.0120 \\
(0.00506)\end{array}$ & $\begin{array}{c}0.0120 \\
(0.00451)\end{array}$ & $\begin{array}{c}0.0115 \\
(0.00507)\end{array}$ & $\begin{array}{c}0.00970 \\
(0.00574)\end{array}$ & $\begin{array}{l}0.00167 \\
(0.0145)\end{array}$ & $\begin{array}{r}-0.00262 \\
(0.0188)\end{array}$ \\
\hline Open-end RE loans & $\begin{array}{c}0.0267 \\
(0.0309)\end{array}$ & $\begin{array}{c}0.0302 \\
(0.0310)\end{array}$ & $\begin{array}{c}0.0268 \\
(0.0266)\end{array}$ & $\begin{array}{c}0.0260 \\
(0.0250)\end{array}$ & $\begin{array}{c}0.0283 \\
(0.0270)\end{array}$ & $\begin{array}{c}0.0303 \\
(0.0292)\end{array}$ & $\begin{array}{c}0.0392 \\
(0.0386)\end{array}$ & $\begin{array}{c}0.0434 \\
(0.0373)\end{array}$ & $\begin{array}{c}0.0385 \\
(0.0324)\end{array}$ & $\begin{array}{c}0.0374 \\
(0.0307)\end{array}$ & $\begin{array}{c}0.0415 \\
(0.0329)\end{array}$ & $\begin{array}{c}0.0448 \\
(0.0335)\end{array}$ \\
\hline Closed-end RE loans & $\begin{array}{c}0.254 \\
(0.148)\end{array}$ & $\begin{array}{c}0.249 \\
(0.149)\end{array}$ & $\begin{array}{c}0.247 \\
(0.151)\end{array}$ & $\begin{array}{c}0.245 \\
(0.150)\end{array}$ & $\begin{array}{c}0.247 \\
(0.148)\end{array}$ & $\begin{array}{c}0.246 \\
(0.142)\end{array}$ & $\begin{array}{c}0.172 \\
(0.113)\end{array}$ & $\begin{array}{c}0.168 \\
(0.111)\end{array}$ & $\begin{array}{c}0.171 \\
(0.113)\end{array}$ & $\begin{array}{c}0.163 \\
(0.105)\end{array}$ & $\begin{array}{c}0.162 \\
(0.104)\end{array}$ & $\begin{array}{c}0.160 \\
(0.0977)\end{array}$ \\
\hline Other RE loans & $\begin{array}{c}0.297 \\
(0.142)\end{array}$ & $\begin{array}{c}0.340 \\
(0.153)\end{array}$ & $\begin{array}{c}0.353 \\
(0.153)\end{array}$ & $\begin{array}{c}0.356 \\
(0.151)\end{array}$ & $\begin{array}{c}0.347 \\
(0.143)\end{array}$ & $\begin{array}{c}0.341 \\
(0.136)\end{array}$ & $\begin{array}{c}0.308 \\
(0.153)\end{array}$ & $\begin{array}{c}0.347 \\
(0.163)\end{array}$ & $\begin{array}{c}0.363 \\
(0.165)\end{array}$ & $\begin{array}{c}0.367 \\
(0.157)\end{array}$ & $\begin{array}{c}0.361 \\
(0.148)\end{array}$ & $\begin{array}{c}0.353 \\
(0.139)\end{array}$ \\
\hline Commercial and industrial loan & $\begin{array}{c}0.0276 \\
(0.0602)\end{array}$ & $\begin{array}{c}0.0411 \\
(0.0678)\end{array}$ & $\begin{array}{c}0.0412 \\
(0.0656)\end{array}$ & $\begin{array}{c}0.0450 \\
(0.0666)\end{array}$ & $\begin{array}{c}0.0480 \\
(0.0679)\end{array}$ & $\begin{array}{c}0.0471 \\
(0.0650)\end{array}$ & $\begin{array}{c}0.117 \\
(0.0797)\end{array}$ & $\begin{array}{c}0.116 \\
(0.0732)\end{array}$ & $\begin{array}{c}0.119 \\
(0.0720)\end{array}$ & $\begin{array}{c}0.122 \\
(0.0705)\end{array}$ & $\begin{array}{c}0.122 \\
(0.0731)\end{array}$ & $\begin{array}{c}0.113 \\
(0.0670)\end{array}$ \\
\hline Loans to individuals & $\begin{array}{c}0.0664 \\
(0.0613)\end{array}$ & $\begin{array}{c}0.0561 \\
(0.0564)\end{array}$ & $\begin{array}{c}0.0524 \\
(0.0521)\end{array}$ & $\begin{array}{c}0.0492 \\
(0.0499)\end{array}$ & $\begin{array}{c}0.0449 \\
(0.0482)\end{array}$ & $\begin{array}{c}0.0428 \\
(0.0465)\end{array}$ & $\begin{array}{c}0.0642 \\
(0.0681)\end{array}$ & $\begin{array}{c}0.0571 \\
(0.0663)\end{array}$ & $\begin{array}{c}0.0502 \\
(0.0539)\end{array}$ & $\begin{array}{c}0.0478 \\
(0.0543)\end{array}$ & $\begin{array}{c}0.0451 \\
(0.0541)\end{array}$ & $\begin{array}{c}0.0435 \\
(0.0531)\end{array}$ \\
\hline Default rate for RRE loans & $\mid \begin{array}{c}0.00208 \\
(0.00292)\end{array}$ & $\begin{array}{c}0.00191 \\
(0.00271)\end{array}$ & $\begin{array}{c}0.00202 \\
(0.00302)\end{array}$ & $\begin{array}{c}0.00285 \\
(0.00414)\end{array}$ & $\begin{array}{c}0.00460 \\
(0.00565)\end{array}$ & $\begin{array}{c}0.00654 \\
(0.00872)\end{array}$ & $\begin{array}{c}0.00149 \\
(0.00207)\end{array}$ & $\begin{array}{c}0.00118 \\
(0.00143)\end{array}$ & $\begin{array}{c}0.00134 \\
(0.00179)\end{array}$ & $\begin{array}{c}0.00196 \\
(0.00263)\end{array}$ & $\begin{array}{c}0.00378 \\
(0.00440)\end{array}$ & $\begin{array}{c}0.00602 \\
(0.00659)\end{array}$ \\
\hline RRE loan demand & $\begin{array}{c}0.398 \\
(0.790)\end{array}$ & $\begin{array}{c}0.378 \\
(0.692)\end{array}$ & $\begin{array}{c}0.347 \\
(0.624)\end{array}$ & $\begin{array}{c}0.275 \\
(0.337)\end{array}$ & $\begin{array}{c}0.210 \\
(0.239)\end{array}$ & $\begin{array}{c}0.188 \\
(0.241)\end{array}$ & $\begin{array}{c}0.350 \\
(0.563)\end{array}$ & $\begin{array}{c}0.320 \\
(0.413)\end{array}$ & $\begin{array}{c}0.283 \\
(0.275)\end{array}$ & $\begin{array}{c}0.211 \\
(0.168)\end{array}$ & $\begin{array}{c}0.164 \\
(0.152)\end{array}$ & $\begin{array}{c}0.157 \\
(0.147)\end{array}$ \\
\hline Lines of credit for non-RE loans & $\begin{array}{c}0.0557 \\
(0.0943)\end{array}$ & $\begin{array}{c}0.0601 \\
(0.0736)\end{array}$ & $\begin{array}{c}0.0596 \\
(0.0827)\end{array}$ & $\begin{array}{c}0.0568 \\
(0.0443)\end{array}$ & $\begin{array}{c}0.0544 \\
(0.0429)\end{array}$ & $\begin{array}{c}0.0503 \\
(0.0389)\end{array}$ & $\begin{array}{c}0.136 \\
(0.526)\end{array}$ & $\begin{array}{c}0.144 \\
(0.522)\end{array}$ & $\begin{array}{c}0.116 \\
(0.149)\end{array}$ & $\begin{array}{c}0.115 \\
(0.145)\end{array}$ & $\begin{array}{c}0.104 \\
(0.122)\end{array}$ & $\begin{array}{l}0.0982 \\
(0.107)\end{array}$ \\
\hline Lines of credit for RE loans & $\begin{array}{c}0.0547 \\
(0.0485)\end{array}$ & $\begin{array}{c}0.0676 \\
(0.0552)\end{array}$ & $\begin{array}{c}0.0636 \\
(0.0482)\end{array}$ & $\begin{array}{c}0.0551 \\
(0.0460)\end{array}$ & $\begin{array}{c}0.0488 \\
(0.0333)\end{array}$ & $\begin{array}{c}0.0400 \\
(0.0273)\end{array}$ & $\begin{array}{c}0.0781 \\
(0.0507)\end{array}$ & $\begin{array}{c}0.101 \\
(0.0637)\end{array}$ & $\begin{array}{c}0.101 \\
(0.0612)\end{array}$ & $\begin{array}{c}0.0955 \\
(0.0555)\end{array}$ & $\begin{array}{c}0.0734 \\
(0.0427)\end{array}$ & $\begin{array}{c}0.0581 \\
(0.0342)\end{array}$ \\
\hline Core-deposit funding & $\begin{array}{c}0.701 \\
(0.0919)\end{array}$ & $\begin{array}{c}0.672 \\
(0.102)\end{array}$ & $\begin{array}{c}0.650 \\
(0.102)\end{array}$ & $\begin{array}{c}0.641 \\
(0.0919)\end{array}$ & $\begin{array}{c}0.634 \\
(0.0944)\end{array}$ & $\begin{array}{c}0.648 \\
(0.0904)\end{array}$ & $\begin{array}{c}0.618 \\
(0.147)\end{array}$ & $\begin{array}{c}0.589 \\
(0.150)\end{array}$ & $\begin{array}{c}0.577 \\
(0.142)\end{array}$ & $\begin{array}{c}0.576 \\
(0.136)\end{array}$ & $\begin{array}{c}0.582 \\
(0.123)\end{array}$ & $\begin{array}{c}0.611 \\
(0.125)\end{array}$ \\
\hline Observations & 1,743 & 1,677 & 1,587 & 1,526 & 1,454 & 1,392 & 372 & 369 & 351 & 326 & 306 & 281 \\
\hline
\end{tabular}

Source: Reports of Condition and income

Notes: This table displays summary statistics for commercial banks for years 2004, 2006-2010. The left panel displays statistics for banks with an average asset size less than $\$ 1$ billion and the right panel for banks with an average asset size greater than $\$ 1$ billion. The averages are taken over all banks for each of the six years of observations. Bank financial variables are obtained from end of previous year (fourth quarter) Call Reports. Standard deviations in parentheses. 
Table IV

Estimates for the first-stage specification shown in Equation 2

\begin{tabular}{|c|c|c|c|c|c|c|}
\hline & \multicolumn{6}{|c|}{ Dependent Variable: Approval Decision } \\
\hline COEFFICIENT & $\lambda_{2004}$ & $\lambda_{2006}$ & $\lambda_{2007}$ & $\lambda_{2008}$ & $\lambda_{2009}$ & $\lambda_{2010}$ \\
\hline Minority & $\begin{array}{c}-0.510 * * * \\
(0.0562)\end{array}$ & $\begin{array}{c}-0.496 * * * \\
(0.0642)\end{array}$ & $\begin{array}{c}-0.631 * * * * \\
(0.0662)\end{array}$ & $\begin{array}{c}-0.654^{* * * *} \\
(0.0416)\end{array}$ & $\begin{array}{c}-0.653^{* * * *} \\
(0.0365)\end{array}$ & $\begin{array}{c}-0.569 * * * \\
(0.0374)\end{array}$ \\
\hline Female & $\begin{array}{c}-0.0690 * * * \\
(0.0146)\end{array}$ & $\begin{array}{c}-0.0548^{* * *} \\
(0.0166)\end{array}$ & $\begin{array}{c}-0.0681 * * * \\
(0.0214)\end{array}$ & $\begin{array}{c}-0.0439 * * \\
(0.0194)\end{array}$ & $\begin{array}{c}-0.0577 * * * \\
(0.0183)\end{array}$ & $\begin{array}{c}-0.0511^{* * *} \\
(0.0106)\end{array}$ \\
\hline Sex not reported & $\begin{array}{c}-0.654 * * * \\
(0.0781)\end{array}$ & $\begin{array}{c}-0.429 * * * \\
(0.0416)\end{array}$ & $\begin{array}{c}-0.450 * * * * \\
(0.0571)\end{array}$ & $\begin{array}{c}-0.358^{* * * *} \\
(0.0660)\end{array}$ & $\begin{array}{c}-0.395 * * * \\
(0.0611)\end{array}$ & $\begin{array}{c}-0.479 * * * * \\
(0.0420)\end{array}$ \\
\hline Loan to Income Ratio & $\mid \begin{array}{c}-0.106 * * * \\
(0.0252)\end{array}$ & $\begin{array}{c}-0.127 * * * \\
(0.0271)\end{array}$ & $\begin{array}{c}-0.153^{* * *} \\
(0.0254)\end{array}$ & $\begin{array}{c}-0.147 * * * \\
(0.0357)\end{array}$ & $\begin{array}{c}-0.146 * * * \\
(0.0317)\end{array}$ & $\begin{array}{c}-0.165 * * * \\
(0.0203)\end{array}$ \\
\hline log Income & $\begin{array}{l}0.391 * * * \\
(0.0782)\end{array}$ & $\begin{array}{l}0.337 * * * \\
(0.0617)\end{array}$ & $\begin{array}{c}0.300^{* * *} \\
(0.0532)\end{array}$ & $\begin{array}{c}0.299 * * * \\
(0.0557)\end{array}$ & $\begin{array}{l}0.302^{* * *} \\
(0.0603)\end{array}$ & $\begin{array}{c}0.307^{* * *} \\
(0.0499)\end{array}$ \\
\hline log Loan amount & \begin{tabular}{|c|}
$0.237 * * *$ \\
$(0.0624)$
\end{tabular} & \begin{tabular}{|c|}
$0.153 * * *$ \\
$(0.0312)$
\end{tabular} & $\begin{array}{c}0.155^{* * *} \\
(0.0391)\end{array}$ & $\begin{array}{c}0.189 * * * \\
(0.0730)\end{array}$ & $\begin{array}{c}0.288^{* * *} \\
(0.0569)\end{array}$ & $\begin{array}{c}0.295^{* * * *} \\
(0.0333)\end{array}$ \\
\hline Jumbo & $\mid \begin{array}{c}-0.704^{* * *} \\
(0.0815)\end{array}$ & \begin{tabular}{|c}
$-0.635 * * *$ \\
$(0.0662)$
\end{tabular} & $\begin{array}{c}-0.605 * * * \\
(0.0468)\end{array}$ & $\begin{array}{c}-0.901 * * * \\
(0.0653)\end{array}$ & $\begin{array}{c}-0.872^{* * *} \\
(0.0902)\end{array}$ & $\begin{array}{c}-0.634^{* * *} \\
(0.0675)\end{array}$ \\
\hline Junior Lien & \begin{tabular}{|c|}
$-0.281^{* * *}$ \\
$(0.0992)$
\end{tabular} & $\begin{array}{l}-0.205^{*} \\
(0.110)\end{array}$ & $\begin{array}{c}-0.431 * * * \\
(0.130)\end{array}$ & $\begin{array}{c}-0.636 * * * \\
(0.136)\end{array}$ & $\begin{array}{c}-0.959 * * * \\
(0.215)\end{array}$ & $\begin{array}{c}-0.830 * * * \\
(0.153)\end{array}$ \\
\hline No Lien on Dweling & $\begin{array}{c}-0.445 * * \\
(0.173)\end{array}$ & $\begin{array}{l}-0.188 \\
(0.481)\end{array}$ & $\begin{array}{l}-0.379 \\
(0.401)\end{array}$ & $\begin{array}{c}-0.123 \\
(0.412)\end{array}$ & $\begin{array}{c}-0.374^{* *} \\
(0.159)\end{array}$ & $\begin{array}{c}-0.501 * * * \\
(0.137)\end{array}$ \\
\hline Manufactured Housing & $\begin{array}{c}-1.209 * * * \\
(0.122)\end{array}$ & $\begin{array}{c}-1.267 * * * \\
(0.101)\end{array}$ & $\begin{array}{c}-1.165 * * * \\
(0.125)\end{array}$ & $\begin{array}{c}-1.266 * * * \\
(0.115)\end{array}$ & $\begin{array}{c}-1.253^{* * *} \\
(0.160)\end{array}$ & $\begin{array}{c}-1.184^{* * *} \\
(0.177)\end{array}$ \\
\hline Home Improvement Loan & $\begin{array}{c}-1.062^{* * *} \\
(0.228)\end{array}$ & \begin{tabular}{|c}
$-1.184 * * *$ \\
$(0.283)$
\end{tabular} & $\begin{array}{c}-1.133^{* * *} \\
(0.193)\end{array}$ & $\begin{array}{c}-1.364 * * * \\
(0.216)\end{array}$ & $\begin{array}{c}-1.067 * * * \\
(0.115)\end{array}$ & $\begin{array}{c}-1.033^{* * *} \\
(0.132)\end{array}$ \\
\hline Not Owner Occupied & \begin{tabular}{|c|}
$-0.386 * * *$ \\
$(0.0441)$
\end{tabular} & $\begin{array}{c}-0.446 * * * \\
(0.0624)\end{array}$ & $\begin{array}{c}-0.465 * * * \\
(0.0359)\end{array}$ & $\begin{array}{c}-0.452^{* * *} \\
(0.0647)\end{array}$ & $\begin{array}{c}-0.509 * * * \\
(0.0724)\end{array}$ & $\begin{array}{c}-0.487^{* * *} \\
(0.0755)\end{array}$ \\
\hline$=$ & $3,306,785$ & $4,305,279$ & $3,533,218$ & $1,918,489$ & $1,239,72$ & $1,063,26$ \\
\hline
\end{tabular}

Notes: This table shows coefficient estimates and standard errors for the first stage specification shown in Equation 2 . Each year was estimated independently, with observations for lenders with a total combined number of applications accounting for less than $0.5 \%$ of total market activity dropped. Standard errors in parentheses are clustered at the bank level. The levels of statistical significance are ${ }^{* * *} \mathrm{p}<0.01,{ }^{* *} \mathrm{p}<0.05$, and ${ }^{*} \mathrm{p}<0.10$ 
Table V

Estimated second-stage coefficients for the specification shown in Equation 4

\begin{tabular}{|c|c|c|c|c|c|c|}
\hline \multirow[b]{2}{*}{ COEFFICIENT } & \multicolumn{6}{|c|}{ Dependent Variable: Lit } \\
\hline & $\gamma$ & $\delta 2006$ & $\delta 2007$ & $\delta_{2008}$ & $\delta 2009$ & $\delta 2010$ \\
\hline Lines of credit for RE loans & $\begin{array}{c}1.395 * * \\
(0.67)\end{array}$ & $\begin{array}{l}-0.868 \\
(0.63)\end{array}$ & $\begin{array}{c}-1.285^{*} \\
(0.70)\end{array}$ & $\begin{array}{c}-1.888 * * * \\
(0.73)\end{array}$ & $\begin{array}{l}-0.166 \\
(0.94)\end{array}$ & $\begin{array}{l}0.927 \\
(1.21)\end{array}$ \\
\hline Core-deposit funding & $\begin{array}{l}-0.344 \\
(0.21)\end{array}$ & $\begin{array}{l}0.343^{*} \\
(0.19)\end{array}$ & $\begin{array}{c}0.489 * * \\
(0.22)\end{array}$ & $\begin{array}{c}0.796 * * * \\
(0.24)\end{array}$ & $\begin{array}{c}0.715^{* * *} \\
(0.26)\end{array}$ & $\begin{array}{c}0.575 * * \\
(0.28)\end{array}$ \\
\hline log Assets & $\begin{array}{l}0.001 \\
(0.00)\end{array}$ & $\begin{array}{l}0.000 \\
(0.00)\end{array}$ & $\begin{array}{l}0.000 \\
(0.00)\end{array}$ & $\begin{array}{l}-0.000 \\
(0.00)\end{array}$ & $\begin{array}{r}-0.002 \\
(0.00)\end{array}$ & $\begin{array}{r}-0.001 \\
(0.00)\end{array}$ \\
\hline Tier 1 leverage ratio & $\begin{array}{c}2.847^{* * *} \\
(1.01)\end{array}$ & $\begin{array}{l}0.255 \\
(0.94)\end{array}$ & $\begin{array}{l}-0.931 \\
(0.98)\end{array}$ & $\begin{array}{l}0.489 \\
(1.03)\end{array}$ & $\begin{array}{c}-2.230^{* *} \\
(1.09)\end{array}$ & $\begin{array}{c}-2.178^{*} \\
(1.16)\end{array}$ \\
\hline Asset liquidity & $\begin{array}{l}0.168 \\
(0.24)\end{array}$ & $\begin{array}{c}-0.601 * * * \\
(0.22)\end{array}$ & $\begin{array}{l}-0.260 \\
(0.26)\end{array}$ & $\begin{array}{c}-0.479 * \\
(0.28)\end{array}$ & $\begin{array}{l}-0.034 \\
(0.31)\end{array}$ & $\begin{array}{l}0.206 \\
(0.30)\end{array}$ \\
\hline Closed-end RE loans & $\begin{array}{l}0.321 \\
(0.28)\end{array}$ & $\begin{array}{l}0.146 \\
(0.17)\end{array}$ & $\begin{array}{l}0.099 \\
(0.18)\end{array}$ & $\begin{array}{c}-0.459 * * \\
(0.21)\end{array}$ & $\begin{array}{c}-0.738^{* * *} \\
(0.22)\end{array}$ & $\begin{array}{c}-0.827^{* * *} \\
(0.23)\end{array}$ \\
\hline Open-end RE loans & $\begin{array}{l}-0.193 \\
(1.23)\end{array}$ & $\begin{array}{l}-0.022 \\
(0.86)\end{array}$ & $\begin{array}{l}-0.145 \\
(0.95)\end{array}$ & $\begin{array}{r}-0.878 \\
(1.11)\end{array}$ & $\begin{array}{c}-5.166^{* * *} \\
(1.21)\end{array}$ & $\begin{array}{c}-5.686 * * * \\
(1.25)\end{array}$ \\
\hline Other RE loans & $\begin{array}{l}-0.251 \\
(0.26)\end{array}$ & $\begin{array}{l}0.217 \\
(0.18)\end{array}$ & $\begin{array}{l}0.240 \\
(0.19)\end{array}$ & $\begin{array}{l}0.038 \\
(0.21)\end{array}$ & $\begin{array}{c}-0.445^{*} \\
(0.23)\end{array}$ & $\begin{array}{c}-0.563^{* *} \\
(0.23)\end{array}$ \\
\hline $\begin{array}{l}\text { Lender and Year FE } \\
\text { Additional Controls } \\
\text { Number of observations }\end{array}$ & & & & & & \\
\hline R2 & & & & & & \\
\hline
\end{tabular}

Notes: This table shows the estimated coefficients and standard errors for the specification shown in Equation 4 . The first column shows the base 2004 values and the other columns show structural adjustments from 2004 levels. Standard errors in parentheses are clustered at the bank level. The levels of statistical significance are ${ }^{* * *} \mathrm{p}<0.01,{ }^{* *} \mathrm{p}<0.05$, and ${ }^{*} \mathrm{p}<0.10$ 
Table VI

Second-stage coefficients for the specification shown in Equation 4 for the split sample

(a) Lenders with Assets $<\$ 1$ billion

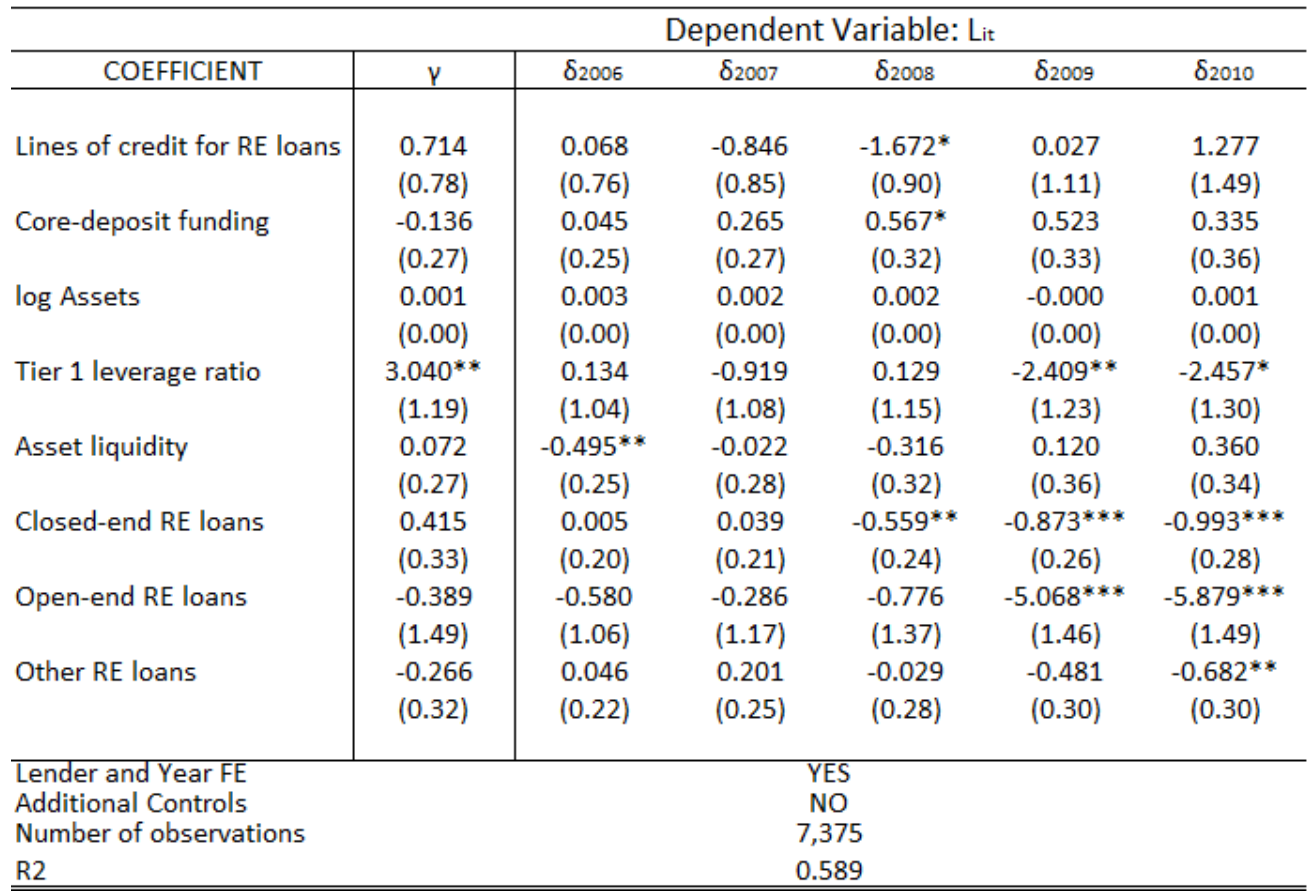

(b) Lenders with Assets $>\$ 1$ billion

\begin{tabular}{|c|c|c|c|c|c|c|}
\hline \multirow[b]{2}{*}{ COEFFICIENT } & \multicolumn{6}{|c|}{ Dependent Variable: Lit } \\
\hline & $\gamma$ & $\delta 2006$ & $\delta 2007$ & $\delta 2008$ & $\delta 2009$ & $\delta 2010$ \\
\hline Lines of credit for RE loans & $\begin{array}{c}3.079 * * \\
(1.23)\end{array}$ & $\begin{array}{c}-2.836^{* *} \\
(1.10)\end{array}$ & $\begin{array}{c}-2.813^{* *} \\
(1.25)\end{array}$ & $\begin{array}{c}-2.743^{* *} \\
(1.13)\end{array}$ & $\begin{array}{l}0.100 \\
(1.72)\end{array}$ & $\begin{array}{l}0.231 \\
(1.97)\end{array}$ \\
\hline Core-deposit funding & $\begin{array}{l}-0.505 \\
(0.34)\end{array}$ & $\begin{array}{l}0.524^{*} \\
(0.28)\end{array}$ & $\begin{array}{c}0.738 * * \\
(0.37)\end{array}$ & $\begin{array}{c}1.091 * * * \\
(0.35)\end{array}$ & $\begin{array}{l}0.800^{*} \\
(0.42)\end{array}$ & $\begin{array}{l}0.769^{*} \\
(0.43)\end{array}$ \\
\hline log Assets & $\begin{array}{l}0.000 \\
(0.00)\end{array}$ & $\begin{array}{l}0.001 \\
(0.00)\end{array}$ & $\begin{array}{l}0.001 \\
(0.00)\end{array}$ & $\begin{array}{l}0.000 \\
(0.00)\end{array}$ & $\begin{array}{l}-0.001 \\
(0.00)\end{array}$ & $\begin{array}{l}0.000 \\
(0.00)\end{array}$ \\
\hline Tier 1 leverage ratio & $\begin{array}{c}3.675^{* *} \\
(1.80)\end{array}$ & $\begin{array}{l}-1.297 \\
(2.15)\end{array}$ & $\begin{array}{l}-2.677 \\
(2.20)\end{array}$ & $\begin{array}{l}1.956 \\
(2.38)\end{array}$ & $\begin{array}{l}-2.026 \\
(2.21)\end{array}$ & $\begin{array}{l}-2.135 \\
(2.28)\end{array}$ \\
\hline Asset liquidity & $\begin{array}{l}0.415 \\
(0.44)\end{array}$ & $\begin{array}{c}-1.004^{* *} \\
(0.46)\end{array}$ & $\begin{array}{c}-1.225 * * \\
(0.58)\end{array}$ & $\begin{array}{c}-0.950^{*} \\
(0.51)\end{array}$ & $\begin{array}{l}-0.552 \\
(0.60)\end{array}$ & $\begin{array}{l}-0.204 \\
(0.52)\end{array}$ \\
\hline Closed-end RE loans & $\begin{array}{l}-0.119 \\
(0.48)\end{array}$ & $\begin{array}{l}0.342 \\
(0.32)\end{array}$ & $\begin{array}{l}0.292 \\
(0.40)\end{array}$ & $\begin{array}{l}0.070 \\
(0.39)\end{array}$ & $\begin{array}{l}-0.097 \\
(0.43)\end{array}$ & $\begin{array}{l}-0.134 \\
(0.43)\end{array}$ \\
\hline Open-end RE loans & $\begin{array}{l}0.874 \\
(1.99)\end{array}$ & $\begin{array}{l}1.800 \\
(1.30)\end{array}$ & $\begin{array}{l}0.441 \\
(1.47)\end{array}$ & $\begin{array}{r}-1.319 \\
(1.48)\end{array}$ & $\begin{array}{c}-5.851 * * * \\
(2.06)\end{array}$ & $\begin{array}{c}-4.902 * * \\
(2.11)\end{array}$ \\
\hline Other RE loans & $\begin{array}{l}-0.153 \\
(0.41)\end{array}$ & $\begin{array}{l}0.418 \\
(0.29)\end{array}$ & $\begin{array}{l}0.325 \\
(0.30)\end{array}$ & $\begin{array}{l}0.110 \\
(0.34)\end{array}$ & $\begin{array}{l}-0.527 \\
(0.39)\end{array}$ & $\begin{array}{l}-0.400 \\
(0.39)\end{array}$ \\
\hline $\begin{array}{l}\text { Lender and Year FE } \\
\text { Additional Controls } \\
\text { Number of observations }\end{array}$ & \multicolumn{6}{|c|}{$\begin{array}{l}\text { YES } \\
\text { NO } \\
2,005\end{array}$} \\
\hline R2 & \multicolumn{6}{|c|}{0.757} \\
\hline
\end{tabular}

Notes: Estimated second-stage coefficients for the specification shown in Equation 4 for lenders with Assets $<\$ 1$ billion (panel a) and lenders with Assets $>\$ 1$ billion (panel b). The first column shows the base 2004 values and the other columns show structural adjustments from 2004 levels. Standard errors in parentheses are clustered at the bank level. The levels of statistical significance are ${ }^{* * *} \mathrm{p}<0.01,{ }^{* *} \mathrm{p}<0.05$, and ${ }^{*} \mathrm{p}<0.10$ 
Table VII

First-stage coeffcients for the specification with a more expansive set of controls shown in Equation 5

(a) Original set of controls

\begin{tabular}{|c|c|c|c|c|c|c|}
\hline \multicolumn{7}{|c|}{ Dependent Variable: Approval Decision } \\
\hline COEFFICIENT & $\lambda_{2004}$ & $\lambda_{2006}$ & $\lambda_{2007}$ & $\lambda_{2008}$ & $\lambda_{2009}$ & $\lambda_{2010}$ \\
\hline Minority & $\begin{array}{c}-0.496 * * * \\
(0.0554)\end{array}$ & $\begin{array}{c}-0.399 * * * \\
(0.0535)\end{array}$ & $\begin{array}{c}-0.513^{* * *} \\
(0.0546)\end{array}$ & $\begin{array}{c}-0.526 * * * \\
(0.0336)\end{array}$ & $\begin{array}{c}-0.518^{* * *} \\
(0.0344)\end{array}$ & $\begin{array}{c}-0.455^{* * *} \\
(0.0359)\end{array}$ \\
\hline Female & $\begin{array}{c}-0.0688^{* * *} \\
(0.0146)\end{array}$ & $\begin{array}{c}-0.0556^{* * *} \\
(0.0164)\end{array}$ & $\begin{array}{c}-0.0689 * * * \\
(0.0210)\end{array}$ & $\begin{array}{c}-0.0452^{* *} \\
(0.0189)\end{array}$ & $\begin{array}{c}-0.0595^{* * *} \\
(0.0180)\end{array}$ & $\begin{array}{c}-0.0515^{* * *} \\
(0.0108)\end{array}$ \\
\hline Sex not reported & $\begin{array}{c}-0.653^{* * *} \\
(0.0777)\end{array}$ & $\begin{array}{c}-0.411^{* * *} \\
(0.0408)\end{array}$ & $\begin{array}{c}-0.428^{* * *} \\
(0.0539)\end{array}$ & $\begin{array}{c}-0.333^{* * *} \\
(0.0610)\end{array}$ & $\begin{array}{c}-0.375 * * * \\
(0.0598)\end{array}$ & $\begin{array}{c}-0.461 * * * \\
(0.0421)\end{array}$ \\
\hline Loan to Income Ratio & $\begin{array}{c}-0.107^{* * *} \\
(0.0254)\end{array}$ & $\begin{array}{c}-0.136^{* * *} \\
(0.0275)\end{array}$ & $\begin{array}{c}-0.162^{* * *} \\
(0.0252)\end{array}$ & $\begin{array}{c}-0.157^{* * * *} \\
(0.0357)\end{array}$ & $\begin{array}{c}-0.157^{* * *} \\
(0.0325)\end{array}$ & $\begin{array}{c}-0.173^{* * *} \\
(0.0209)\end{array}$ \\
\hline log Income & $\begin{array}{l}0.383^{* * *} \\
(0.0778)\end{array}$ & $\begin{array}{l}0.285 * * * \\
(0.0590)\end{array}$ & $\begin{array}{l}0.239 * * * \\
(0.0531)\end{array}$ & $\begin{array}{c}0.239 * * * \\
(0.0522)\end{array}$ & $\begin{array}{l}0.244^{* * *} \\
(0.0634)\end{array}$ & $\begin{array}{l}0.263^{* * *} \\
(0.0508)\end{array}$ \\
\hline log Loan amount & $\begin{array}{c}0.234^{* * *} \\
(0.0623)\end{array}$ & $\begin{array}{c}0.133 * * * \\
(0.0319)\end{array}$ & $\begin{array}{c}0.132^{* * *} \\
(0.0381)\end{array}$ & $\begin{array}{l}0.168 * * \\
(0.0698)\end{array}$ & $\begin{array}{c}0.258^{* * *} \\
(0.0521)\end{array}$ & $\begin{array}{c}0.268^{* * *} \\
(0.0309)\end{array}$ \\
\hline Jumbo & $\begin{array}{c}-0.704^{* * *} \\
(0.0773)\end{array}$ & $\begin{array}{c}-0.658^{* * *} \\
(0.0615)\end{array}$ & $\begin{array}{c}-0.636^{* * *} \\
(0.0502)\end{array}$ & $\begin{array}{c}-0.944^{* * * *} \\
(0.0616)\end{array}$ & $\begin{array}{c}-0.947 * * * \\
(0.0880)\end{array}$ & $\begin{array}{c}-0.705^{* * *} \\
(0.0686)\end{array}$ \\
\hline Junior Lien & $\begin{array}{c}-0.286^{* * *} \\
(0.100)\end{array}$ & $\begin{array}{c}-0.260^{* *} \\
(0.114)\end{array}$ & $\begin{array}{c}-0.494^{* * *} \\
(0.135)\end{array}$ & $\begin{array}{c}-0.694^{* * *} \\
(0.135)\end{array}$ & $\begin{array}{c}-1.015^{* * *} \\
(0.220)\end{array}$ & $\begin{array}{c}-0.876^{* * *} \\
(0.156)\end{array}$ \\
\hline No Lien on Dweling & $\begin{array}{c}-0.455^{* * *} \\
(0.173)\end{array}$ & $\begin{array}{l}-0.273 \\
(0.480)\end{array}$ & $\begin{array}{l}-0.473 \\
(0.397)\end{array}$ & $\begin{array}{l}-0.211 \\
(0.394)\end{array}$ & $\begin{array}{c}-0.444^{* * *} \\
(0.164)\end{array}$ & $\begin{array}{c}-0.557^{* * *} \\
(0.140)\end{array}$ \\
\hline Manufactured Housing & $\begin{array}{c}-1.205^{* * *} \\
(0.123)\end{array}$ & $\begin{array}{c}-1.282^{* * *} \\
(0.104)\end{array}$ & $\begin{array}{c}-1.178^{* * *} \\
(0.131)\end{array}$ & $\begin{array}{c}-1.278^{* * * *} \\
(0.120)\end{array}$ & $\begin{array}{c}-1.285^{* * *} \\
(0.163)\end{array}$ & $\begin{array}{c}-1.220 * * * \\
(0.178)\end{array}$ \\
\hline Home Improvement Loan & $\begin{array}{c}-1.058^{* * *} \\
(0.231)\end{array}$ & $\begin{array}{c}-1.181^{* * *} \\
(0.285)\end{array}$ & $\begin{array}{c}-1.129 * * * \\
(0.193)\end{array}$ & $\begin{array}{c}-1.355^{* * *} \\
(0.215)\end{array}$ & $\begin{array}{c}-1.074^{* * *} \\
(0.117)\end{array}$ & $\begin{array}{c}-1.038^{* * *} \\
(0.134)\end{array}$ \\
\hline Not Owner Occupied & $\begin{array}{c}-0.379 * * * \\
(0.0438)\end{array}$ & $\begin{array}{c}-0.397 * * * \\
(0.0593)\end{array}$ & $\begin{array}{c}-0.401^{* * *} \\
(0.0360)\end{array}$ & $\begin{array}{c}-0.388^{* * *} \\
(0.0637)\end{array}$ & $\begin{array}{c}-0.448 * * * \\
(0.0697)\end{array}$ & $\begin{array}{c}-0.440^{* * *} \\
(0.0732)\end{array}$ \\
\hline Bank-County, Census-Tract terms & YES & YES & YES & YES & YES & YES \\
\hline Number of observations & $3,305,181$ & $4,302,772$ & $3,531,169$ & $1,917,121$ & $1,238,566$ & $1,062,324$ \\
\hline
\end{tabular}

(b) Additional controls

\begin{tabular}{|c|c|c|c|c|c|c|}
\hline \multirow[b]{2}{*}{ COEFFICIENT } & \multicolumn{6}{|c|}{ Dependent Variable: Approval Decision } \\
\hline & $\lambda_{2004}$ & $\lambda_{2006}$ & $\lambda_{2007}$ & $\lambda_{2008}$ & $\lambda_{2009}$ & $\lambda_{2010}$ \\
\hline BL Portfolio Concentration & $\begin{array}{l}0.474^{* * *} \\
(0.0661)\end{array}$ & $\begin{array}{c}0.462^{* * *} \\
(0.0711)\end{array}$ & $\begin{array}{l}0.420 * * * \\
(0.0823)\end{array}$ & $\begin{array}{c}0.377^{* * *} \\
(0.0599)\end{array}$ & $\begin{array}{l}0.341 * * * \\
(0.0652)\end{array}$ & $\begin{array}{l}0.378^{* * *} \\
(0.0621)\end{array}$ \\
\hline BL Market Share & $\begin{array}{c}0.866^{* * *} \\
(0.330)\end{array}$ & $\begin{array}{c}1.144^{* * *} \\
(0.324)\end{array}$ & $\begin{array}{c}2.069 * * * \\
(0.397)\end{array}$ & $\begin{array}{c}1.532^{* * *} \\
(0.425)\end{array}$ & $\begin{array}{c}1.287^{* * *} \\
(0.400)\end{array}$ & $\begin{array}{c}1.518^{* * * *} \\
(0.301)\end{array}$ \\
\hline BL Pct Subprime & $\begin{array}{l}-0.239 * \\
(0.143)\end{array}$ & $\begin{array}{l}-0.267 \\
(0.224)\end{array}$ & $\begin{array}{l}-0.396^{*} \\
(0.218)\end{array}$ & $\begin{array}{l}-0.124 \\
(0.302)\end{array}$ & $\begin{array}{c}0.22 \\
(0.138)\end{array}$ & $\begin{array}{c}0.319 * * * \\
(0.102)\end{array}$ \\
\hline BL Pct Sold GSE & $\begin{array}{c}0.477^{* * *} \\
(0.134)\end{array}$ & $\begin{array}{l}0.297 \\
(0.199)\end{array}$ & $\begin{array}{c}0.371^{* * *} \\
(0.140)\end{array}$ & $\begin{array}{c}0.542^{* * *} \\
(0.135)\end{array}$ & $\begin{array}{c}0.401 * * * \\
(0.121)\end{array}$ & $\begin{array}{l}0.0922 \\
(0.123)\end{array}$ \\
\hline BL Pct Sold Affiliate & $\begin{array}{c}0.302 \\
(0.193)\end{array}$ & $\begin{array}{c}0.181 \\
(0.265)\end{array}$ & $\begin{array}{l}0.0862 \\
(0.230)\end{array}$ & $\begin{array}{c}0.148 \\
(0.248)\end{array}$ & $\begin{array}{c}0.369 \\
(0.313)\end{array}$ & $\begin{array}{c}0.468 * * * \\
(0.118)\end{array}$ \\
\hline BL Pct Sold Commercial & $\begin{array}{l}-0.545 \\
(0.332)\end{array}$ & $\begin{array}{c}0.406 \\
(0.281)\end{array}$ & $\begin{array}{c}0.309 \\
(0.203)\end{array}$ & $\begin{array}{c}0.315 \\
(0.239)\end{array}$ & $\begin{array}{l}0.384 * * \\
(0.191)\end{array}$ & $\begin{array}{c}0.28 \\
(0.190)\end{array}$ \\
\hline BL Pct Sold Private Securitization & $\begin{array}{l}-1.941 \\
(1.238)\end{array}$ & $\begin{array}{c}-2.557^{* * *} \\
(0.409)\end{array}$ & $\begin{array}{c}-0.985 * * * \\
(0.249)\end{array}$ & $\begin{array}{c}-8.708 * * * \\
(1.306)\end{array}$ & $\begin{array}{c}0.246 \\
(0.839)\end{array}$ & $\begin{array}{l}-0.335 \\
(0.217)\end{array}$ \\
\hline BL Pct Sold to Other Institutions & $\begin{array}{l}-0.108 \\
(0.180)\end{array}$ & $\begin{array}{c}0.189 \\
(0.202)\end{array}$ & $\begin{array}{l}0.550^{* *} \\
(0.228)\end{array}$ & $\begin{array}{c}0.676^{* * *} \\
(0.181)\end{array}$ & $\begin{array}{c}0.559 * * * \\
(0.177)\end{array}$ & $\begin{array}{c}0.478^{* * *} \\
(0.157)\end{array}$ \\
\hline BL Pct Sold to Mortgage Company & $\begin{array}{c}0.397 \\
(0.254)\end{array}$ & $\begin{array}{l}-0.505 \\
(0.346)\end{array}$ & $\begin{array}{l}-0.317 \\
(0.306)\end{array}$ & $\begin{array}{c}0.159 \\
(0.187)\end{array}$ & $\begin{array}{c}0.174 \\
(0.203)\end{array}$ & $\begin{array}{c}0.193 \\
(0.215)\end{array}$ \\
\hline Tract Income & $\begin{array}{c}0.000867^{* * *} \\
(0.000240)\end{array}$ & $\begin{array}{c}0.00245^{* * *} \\
(0.000322)\end{array}$ & $\begin{array}{c}0.00295^{* * *} \\
(0.000240)\end{array}$ & $\begin{array}{c}0.00302^{* * *} \\
(0.000492)\end{array}$ & $\begin{array}{c}0.00301^{* * *} \\
(0.000211)\end{array}$ & $\begin{array}{c}0.00220^{* * *} \\
(0.000232)\end{array}$ \\
\hline Tract Pct Minority & $\begin{array}{c}-0.000639 * * * \\
(8.93 e-05)\end{array}$ & $\begin{array}{c}-0.00336 * * * \\
(0.000628)\end{array}$ & $\begin{array}{c}-0.00409 * * * \\
(0.000767)\end{array}$ & $\begin{array}{c}-0.00435 * * * \\
(0.000582)\end{array}$ & $\begin{array}{c}-0.00521^{* * *} \\
(0.000847)\end{array}$ & $\begin{array}{c}-0.00497 * * * \\
(0.000713)\end{array}$ \\
\hline Number of observations & $3,305,181$ & $4,302,772$ & $3,531,169$ & $1,917,121$ & $1,238,566$ & $1,062,324$ \\
\hline
\end{tabular}

Notes: This table shows estimates for the first-stage specification which includes a more expansive set of control variables, shown in Equation 5. Each year was estimated independently, with observations for lenders with a total combined number of applications accounting for less than $0.5 \%$ of total market activity dropped. The table shows coefficients and standard errors for the original set of controls (panel a) as well as for the additional controls (panel b). Standard errors in parentheses are clustered at the bank level. The levels of statistical significance are ${ }^{* * *} \mathrm{p}<0.01,{ }^{* *} \mathrm{p}<0.05$, and ${ }^{*} \mathrm{p}<0.10$ 
Table VIII

Correlations of estimated supply effects from the parsimonious and richer first stage models

\begin{tabular}{lcccccc}
\hline Year & 2004 & 2006 & 2007 & 2008 & 2009 & 2010 \\
\hline Correlation & 0.978 & 0.976 & 0.977 & 0.973 & 0.988 & 0.987 \\
$99.9 \%$ C.I. & {$[0.974-0.981]$} & {$[0.972-0.980]$} & {$[0.972-0.980]$} & {$[0.968-0.977]$} & {$[0.986-0.990]$} & {$[0.984-0.989]$} \\
\hline \hline
\end{tabular}

Notes: This table shows yearly correlations for the estimated lender-year effects obtained from the parsimonious first-stage model shown in Equation 2 and the one using the more expansive set of controls shown in Equation 5.

Table IX

Second-stage coefficients using the richer first-stage specification shown in Equation 5

(a) Lenders with Assets $<\$ 1$ billion

\begin{tabular}{|c|c|c|c|c|c|c|}
\hline \multirow[b]{2}{*}{ COEFFICIENT } & \multicolumn{6}{|c|}{ Dependent Variable: Lit } \\
\hline & $\gamma$ & $\delta 2006$ & $\delta 2007$ & $\delta 2008$ & $\delta 2009$ & $\delta 2010$ \\
\hline Lines of credit for RE loans & $\begin{array}{l}0.932 \\
(0.78)\end{array}$ & $\begin{array}{l}-0.181 \\
(0.77)\end{array}$ & $\begin{array}{r}-1.202 \\
(0.87)\end{array}$ & $\begin{array}{c}-1.786^{*} \\
(0.92)\end{array}$ & $\begin{array}{l}0.134 \\
(1.12)\end{array}$ & $\begin{array}{l}1.877 \\
(1.50)\end{array}$ \\
\hline Core-deposit funding & $\begin{array}{l}-0.305 \\
(0.29)\end{array}$ & $\begin{array}{l}0.134 \\
(0.25)\end{array}$ & $\begin{array}{l}0.391 \\
(0.29)\end{array}$ & $\begin{array}{c}0.765^{* *} \\
(0.33)\end{array}$ & $\begin{array}{l}0.642^{*} \\
(0.34)\end{array}$ & $\begin{array}{l}0.489 \\
(0.37)\end{array}$ \\
\hline log Assets & $\begin{array}{l}0.001 \\
(0.00)\end{array}$ & $\begin{array}{l}0.003 \\
(0.00)\end{array}$ & $\begin{array}{l}0.003 \\
(0.00)\end{array}$ & $\begin{array}{l}0.003 \\
(0.00)\end{array}$ & $\begin{array}{l}0.001 \\
(0.00)\end{array}$ & $\begin{array}{l}0.002 \\
(0.00)\end{array}$ \\
\hline Tier 1 leverage ratio & $\begin{array}{c}3.077^{* *} \\
(1.27)\end{array}$ & $\begin{array}{l}-0.361 \\
(1.05)\end{array}$ & $\begin{array}{l}-1.155 \\
(1.11)\end{array}$ & $\begin{array}{l}0.084 \\
(1.18)\end{array}$ & $\begin{array}{c}-2.526^{* *} \\
(1.26)\end{array}$ & $\begin{array}{c}-2.556 * \\
(1.33)\end{array}$ \\
\hline Asset liquidity & $\begin{array}{l}-0.060 \\
(0.28)\end{array}$ & $\begin{array}{c}-0.506^{* *} \\
(0.26)\end{array}$ & $\begin{array}{l}0.014 \\
(0.29)\end{array}$ & $\begin{array}{l}-0.247 \\
(0.33)\end{array}$ & $\begin{array}{l}0.317 \\
(0.36)\end{array}$ & $\begin{array}{l}0.425 \\
(0.36)\end{array}$ \\
\hline Closed-end RE loans & $\begin{array}{l}0.454 \\
(0.34)\end{array}$ & $\begin{array}{l}0.037 \\
(0.20)\end{array}$ & $\begin{array}{l}0.064 \\
(0.22)\end{array}$ & $\begin{array}{c}-0.476^{*} \\
(0.25)\end{array}$ & $\begin{array}{c}-0.710^{* * *} \\
(0.27)\end{array}$ & $\begin{array}{c}-0.909 * * * \\
(0.29)\end{array}$ \\
\hline Open-end RE loans & $\begin{array}{l}-0.582 \\
(1.51)\end{array}$ & $\begin{array}{r}-0.208 \\
(1.06)\end{array}$ & $\begin{array}{r}-0.484 \\
(1.21)\end{array}$ & $\begin{array}{l}-0.776 \\
(1.39)\end{array}$ & $\begin{array}{c}-4.803^{* * *} \\
(1.47)\end{array}$ & $\begin{array}{c}-5.141^{* * *} \\
(1.52)\end{array}$ \\
\hline Other RE loans & $\begin{array}{l}-0.162 \\
(0.32)\end{array}$ & $\begin{array}{l}0.048 \\
(0.22)\end{array}$ & $\begin{array}{l}0.154 \\
(0.25)\end{array}$ & $\begin{array}{l}-0.164 \\
(0.29)\end{array}$ & $\begin{array}{c}-0.587^{*} \\
(0.30)\end{array}$ & $\begin{array}{c}-0.739 * * \\
(0.30)\end{array}$ \\
\hline $\begin{array}{l}\text { Lender and Year FE } \\
\text { Additional Controls } \\
\text { Number of observations }\end{array}$ & & & & & & \\
\hline $\mathrm{R} 2$ & & & & & & \\
\hline
\end{tabular}

(b) Lenders with Assets $>\$ 1$ billion

\begin{tabular}{|c|c|c|c|c|c|c|}
\hline \multirow[b]{2}{*}{ COEFFICIENT } & \multicolumn{6}{|c|}{ Dependent Variable: Lit } \\
\hline & $\gamma$ & $\delta 2006$ & $\delta 2007$ & $\delta 2008$ & $\delta 2009$ & $\delta 2010$ \\
\hline Lines of credit for RE loans & $\begin{array}{c}3.044^{* *} \\
(1.30)\end{array}$ & $\begin{array}{c}-2.356^{*} \\
(1.30)\end{array}$ & $\begin{array}{c}-3.002^{* *} \\
(1.34)\end{array}$ & $\begin{array}{c}-2.905^{* *} \\
(1.18)\end{array}$ & $\begin{array}{l}0.149 \\
(1.78)\end{array}$ & $\begin{array}{l}0.534 \\
(2.05)\end{array}$ \\
\hline Core-deposit funding & $\begin{array}{c}-0.496 \\
(0.36)\end{array}$ & $\begin{array}{l}0.540^{*} \\
(0.29)\end{array}$ & $\begin{array}{c}0.828^{* *} \\
(0.38)\end{array}$ & $\begin{array}{c}1.219^{* * *} \\
(0.36)\end{array}$ & $\begin{array}{l}0.800^{*} \\
(0.43)\end{array}$ & $\begin{array}{l}0.770^{*} \\
(0.43)\end{array}$ \\
\hline log Assets & $\begin{array}{l}-0.000 \\
(0.00)\end{array}$ & $\begin{array}{l}0.001 \\
(0.00)\end{array}$ & $\begin{array}{l}0.001 \\
(0.00)\end{array}$ & $\begin{array}{l}0.001 \\
(0.00)\end{array}$ & $\begin{array}{r}-0.001 \\
(0.00)\end{array}$ & $\begin{array}{l}-0.000 \\
(0.00)\end{array}$ \\
\hline Tier 1 leverage ratio & $\begin{array}{c}3.650^{*} \\
(1.90)\end{array}$ & $\begin{array}{r}-1.704 \\
(2.25)\end{array}$ & $\begin{array}{r}-2.733 \\
(2.32)\end{array}$ & $\begin{array}{l}1.902 \\
(2.51)\end{array}$ & $\begin{array}{r}-1.934 \\
(2.26)\end{array}$ & $\begin{array}{l}-2.218 \\
(2.40)\end{array}$ \\
\hline Asset liquidity & $\begin{array}{l}0.501 \\
(0.45)\end{array}$ & $\begin{array}{c}-1.157^{* * *} \\
(0.44)\end{array}$ & $\begin{array}{c}-1.352^{* *} \\
(0.56)\end{array}$ & $\begin{array}{c}-1.156^{* *} \\
(0.53)\end{array}$ & $\begin{array}{r}-0.602 \\
(0.60)\end{array}$ & $\begin{array}{l}-0.139 \\
(0.53)\end{array}$ \\
\hline Closed-end RE loans & $\begin{array}{l}0.021 \\
(0.47)\end{array}$ & $\begin{array}{c}0.694^{*} \\
(0.38)\end{array}$ & $\begin{array}{l}0.316 \\
(0.41)\end{array}$ & $\begin{array}{l}0.330 \\
(0.40)\end{array}$ & $\begin{array}{l}0.147 \\
(0.44)\end{array}$ & $\begin{array}{l}0.030 \\
(0.44)\end{array}$ \\
\hline Open-end RE loans & $\begin{array}{l}1.270 \\
(2.08)\end{array}$ & $\begin{array}{l}0.701 \\
(1.61)\end{array}$ & $\begin{array}{l}0.163 \\
(1.62)\end{array}$ & $\begin{array}{l}-2.339 \\
(1.60)\end{array}$ & $\begin{array}{c}-6.742^{* * *} \\
(2.16)\end{array}$ & $\begin{array}{c}-5.128 * * \\
(2.25)\end{array}$ \\
\hline Other RE loans & $\begin{array}{l}-0.152 \\
(0.42)\end{array}$ & $\begin{array}{l}0.464 \\
(0.30)\end{array}$ & $\begin{array}{l}0.349 \\
(0.32)\end{array}$ & $\begin{array}{l}0.152 \\
(0.35)\end{array}$ & $\begin{array}{l}-0.497 \\
(0.39)\end{array}$ & $\begin{array}{l}-0.484 \\
(0.38)\end{array}$ \\
\hline $\begin{array}{l}\text { Lender and Year FE } \\
\text { Additional Controls } \\
\text { Number of observations }\end{array}$ & & & & & & \\
\hline $\mathrm{R} 2$ & & & & & & \\
\hline
\end{tabular}

Notes: Estimated second-stage coefficients for the specification shown in Equation 4 for lenders with Assets $<\$ 1$ billion (panel a) and lenders with Assets $>\$ 1$ billion (panel b). The richer set of covariates was used in the first stage. The first column shows the base 2004 values and the other columns show structural adjustments from 2004 levels. Standard errors in parentheses are clustered at the bank level. The levels of statistical significance are ${ }^{* * *} \mathrm{p}<0.01,{ }^{* *} \mathrm{p}<0.05$, and ${ }^{*} \mathrm{p}<0.10$ 
Table X

Second-stage coefficients for a richer second-stage specification

(a) Lenders with Assets $<\$ 1$ billion

\begin{tabular}{|c|c|c|c|c|c|c|}
\hline \multirow[b]{2}{*}{ COEFFICIENT } & \multicolumn{6}{|c|}{ Dependent Variable: Lit } \\
\hline & $\gamma$ & $\delta 2006$ & $\delta_{2007}$ & $\delta_{2008}$ & $\delta 2009$ & $\delta 2010$ \\
\hline Lines of credit for RE loans & $\begin{array}{l}-0.033 \\
(0.82)\end{array}$ & $\begin{array}{r}-0.254 \\
(0.78)\end{array}$ & $\begin{array}{l}-0.847 \\
(0.89)\end{array}$ & $\begin{array}{r}-1.441 \\
(0.94)\end{array}$ & $\begin{array}{l}0.390 \\
(1.17)\end{array}$ & $\begin{array}{l}1.422 \\
(1.55)\end{array}$ \\
\hline Core-deposit funding & $\begin{array}{l}0.005 \\
(0.28)\end{array}$ & $\begin{array}{l}0.072 \\
(0.25)\end{array}$ & $\begin{array}{l}0.175 \\
(0.28)\end{array}$ & $\begin{array}{l}0.396 \\
(0.32)\end{array}$ & $\begin{array}{l}0.342 \\
(0.34)\end{array}$ & $\begin{array}{l}0.273 \\
(0.37)\end{array}$ \\
\hline log Assets & $\begin{array}{l}0.002 \\
(0.00)\end{array}$ & $\begin{array}{l}0.004 \\
(0.00)\end{array}$ & $\begin{array}{l}0.002 \\
(0.00)\end{array}$ & $\begin{array}{l}0.001 \\
(0.00)\end{array}$ & $\begin{array}{l}-0.001 \\
(0.00)\end{array}$ & $\begin{array}{l}0.001 \\
(0.00)\end{array}$ \\
\hline Tier 1 leverage ratio & $\begin{array}{l}2.352^{*} \\
(1.20)\end{array}$ & $\begin{array}{l}0.387 \\
(1.05)\end{array}$ & $\begin{array}{l}-0.106 \\
(1.12)\end{array}$ & $\begin{array}{l}0.410 \\
(1.17)\end{array}$ & $\begin{array}{c}-2.366^{*} \\
(1.25)\end{array}$ & $\begin{array}{c}-2.254^{*} \\
(1.34)\end{array}$ \\
\hline Asset liquidity & $\begin{array}{l}0.102 \\
(0.27)\end{array}$ & $\begin{array}{c}-0.636^{* *} \\
(0.25)\end{array}$ & $\begin{array}{l}-0.172 \\
(0.28)\end{array}$ & $\begin{array}{l}-0.441 \\
(0.32)\end{array}$ & $\begin{array}{r}-0.093 \\
(0.36)\end{array}$ & $\begin{array}{l}0.329 \\
(0.34)\end{array}$ \\
\hline Closed-end RE loans & $\begin{array}{c}0.683^{* *} \\
(0.34)\end{array}$ & $\begin{array}{l}0.176 \\
(0.22)\end{array}$ & $\begin{array}{l}0.238 \\
(0.24)\end{array}$ & $\begin{array}{l}-0.290 \\
(0.27)\end{array}$ & $\begin{array}{c}-0.687^{* *} \\
(0.30)\end{array}$ & $\begin{array}{c}-0.950 * * * \\
(0.32)\end{array}$ \\
\hline Open-end RE loans & $\begin{array}{l}0.432 \\
(1.50)\end{array}$ & $\begin{array}{l}-0.346 \\
(1.07)\end{array}$ & $\begin{array}{l}-0.090 \\
(1.21)\end{array}$ & $\begin{array}{l}-0.819 \\
(1.41)\end{array}$ & $\begin{array}{c}-4.492^{* * *} \\
(1.52)\end{array}$ & $\begin{array}{c}-5.967^{* * * *} \\
(1.54)\end{array}$ \\
\hline Other RE loans & $\begin{array}{l}-0.424 \\
(0.32)\end{array}$ & $\begin{array}{l}0.026 \\
(0.23)\end{array}$ & $\begin{array}{l}0.362 \\
(0.26)\end{array}$ & $\begin{array}{l}0.086 \\
(0.29)\end{array}$ & $\begin{array}{r}-0.223 \\
(0.30)\end{array}$ & $\begin{array}{c}-0.614^{* *} \\
(0.31)\end{array}$ \\
\hline $\begin{array}{l}\text { Lender and Year FE } \\
\text { Additional Controls } \\
\text { Number of observations }\end{array}$ & & & & & & \\
\hline R2 & & & & & & \\
\hline
\end{tabular}

(b) Lenders with Assets $>\$ 1$ billion

\begin{tabular}{|c|c|c|c|c|c|c|}
\hline \multirow[b]{2}{*}{ COEFFICIENT } & \multicolumn{6}{|c|}{ Dependent Variable: Lit } \\
\hline & $\gamma$ & $\delta 2006$ & $\delta 2007$ & $\delta 2008$ & $\delta 2009$ & $\delta 2010$ \\
\hline Lines of credit for RE loans & $\begin{array}{c}2.994 * * \\
(1.29)\end{array}$ & $\begin{array}{c}-2.592^{* *} \\
(1.24)\end{array}$ & $\begin{array}{c}-2.339^{*} \\
(1.38)\end{array}$ & $\begin{array}{c}-2.407^{*} \\
(1.27)\end{array}$ & $\begin{array}{l}0.352 \\
(1.84)\end{array}$ & $\begin{array}{l}0.759 \\
(2.06)\end{array}$ \\
\hline Core-deposit funding & $\begin{array}{c}-0.579^{*} \\
(0.35)\end{array}$ & $\begin{array}{l}0.428 \\
(0.31)\end{array}$ & $\begin{array}{c}0.612^{*} \\
(0.37)\end{array}$ & $\begin{array}{c}1.158^{* * * *} \\
(0.37)\end{array}$ & $\begin{array}{c}0.895^{* *} \\
(0.45)\end{array}$ & $\begin{array}{l}0.850^{*} \\
(0.45)\end{array}$ \\
\hline log Assets & $\begin{array}{l}0.000 \\
(0.00)\end{array}$ & $\begin{array}{l}0.001 \\
(0.00)\end{array}$ & $\begin{array}{l}0.001 \\
(0.00)\end{array}$ & $\begin{array}{l}0.000 \\
(0.00)\end{array}$ & $\begin{array}{r}-0.000 \\
(0.00)\end{array}$ & $\begin{array}{l}0.001 \\
(0.00)\end{array}$ \\
\hline Tier 1 leverage ratio & $\begin{array}{l}3.788^{*} \\
(1.99)\end{array}$ & $\begin{array}{l}-0.833 \\
(2.24)\end{array}$ & $\begin{array}{l}-3.015 \\
(2.39)\end{array}$ & $\begin{array}{l}2.586 \\
(2.53)\end{array}$ & $\begin{array}{l}-2.330 \\
(2.28)\end{array}$ & $\begin{array}{l}-1.507 \\
(2.47)\end{array}$ \\
\hline Asset liquidity & $\begin{array}{l}0.421 \\
(0.46)\end{array}$ & $\begin{array}{c}-0.999 * * \\
(0.48)\end{array}$ & $\begin{array}{c}-1.259 * * \\
(0.60)\end{array}$ & $\begin{array}{c}-0.900^{*} \\
(0.54)\end{array}$ & $\begin{array}{l}-0.770 \\
(0.62)\end{array}$ & $\begin{array}{l}-0.322 \\
(0.52)\end{array}$ \\
\hline Closed-end RE loans & $\begin{array}{l}-0.197 \\
(0.50)\end{array}$ & $\begin{array}{l}0.301 \\
(0.42)\end{array}$ & $\begin{array}{l}0.295 \\
(0.46)\end{array}$ & $\begin{array}{r}-0.043 \\
(0.50)\end{array}$ & $\begin{array}{l}-0.402 \\
(0.54)\end{array}$ & $\begin{array}{l}-0.096 \\
(0.56)\end{array}$ \\
\hline Open-end RE loans & $\begin{array}{l}1.253 \\
(2.04)\end{array}$ & $\begin{array}{l}1.581 \\
(1.47)\end{array}$ & $\begin{array}{l}0.196 \\
(1.58)\end{array}$ & $\begin{array}{l}-1.992 \\
(1.65)\end{array}$ & $\begin{array}{c}-5.653^{* *} \\
(2.22)\end{array}$ & $\begin{array}{c}-5.128 * * \\
(2.23)\end{array}$ \\
\hline Other RE loans & $\begin{array}{l}-0.155 \\
(0.43)\end{array}$ & $\begin{array}{l}0.434 \\
(0.31)\end{array}$ & $\begin{array}{l}0.285 \\
(0.33)\end{array}$ & $\begin{array}{l}0.058 \\
(0.41)\end{array}$ & $\begin{array}{c}-0.895^{*} \\
(0.47)\end{array}$ & $\begin{array}{l}-0.605 \\
(0.46)\end{array}$ \\
\hline $\begin{array}{l}\text { Lender and Year FE } \\
\text { Additional Controls } \\
\text { Number of observations }\end{array}$ & \multicolumn{6}{|c|}{$\begin{array}{l}\text { YES } \\
\text { YES } \\
2,005\end{array}$} \\
\hline R2 & \multicolumn{6}{|c|}{0.767} \\
\hline
\end{tabular}

Notes: Estimated second-stage coefficients for the specification shown in Equation 4 for lenders with Assets $<\$ 1$ billion (panel a) and lenders with Assets $>\$ 1$ billion (panel b). The richer set of covariates was used in the second stage. For comparison purposes with Table VI, the parsimonious model was used in the first stage. The first column shows the base 2004 values and the other columns show structural adjustments from 2004 levels. Standard errors in parentheses are clustered at the bank level. The levels of statistical significance are ${ }^{* * *} \mathrm{p}<0.01,{ }^{* *} \mathrm{p}<0.05$, and ${ }^{*} \mathrm{p}<0.10$ 
Table XI

Second-stage coefficients using richer specifications in both stages

(a) Lenders with Assets $<\$ 1$ billion

\begin{tabular}{|c|c|c|c|c|c|c|}
\hline & \multicolumn{6}{|c|}{ Dependent Variable: Lit } \\
\hline COEFFICIENT & $\gamma$ & $\delta 2006$ & $\delta_{2007}$ & $\delta 2008$ & $\delta 2009$ & $\delta 2010$ \\
\hline \multirow[t]{2}{*}{ Lines of credit for RE loans } & 0.004 & -0.294 & -0.849 & -1.380 & 0.659 & 2.013 \\
\hline & $(0.83)$ & $(0.79)$ & $(0.91)$ & $(0.97)$ & (1.17) & $(1.56)$ \\
\hline \multirow[t]{2}{*}{ Core-deposit funding } & -0.155 & 0.130 & 0.253 & $0.566^{*}$ & 0.446 & 0.420 \\
\hline & $(0.29)$ & $(0.26)$ & $(0.30)$ & $(0.33)$ & $(0.35)$ & $(0.38)$ \\
\hline \multirow[t]{2}{*}{ log Assets } & 0.002 & 0.003 & 0.003 & 0.002 & 0.000 & 0.001 \\
\hline & $(0.00)$ & $(0.00)$ & $(0.00)$ & $(0.00)$ & $(0.00)$ & $(0.00)$ \\
\hline \multirow[t]{2}{*}{ Tier 1 leverage ratio } & $2.290^{*}$ & -0.120 & -0.415 & 0.320 & $-2.510 * *$ & $-2.396^{*}$ \\
\hline & $(1.26)$ & $(1.05)$ & $(1.15)$ & $(1.20)$ & $(1.28)$ & $(1.37)$ \\
\hline \multirow[t]{2}{*}{ Asset liquidity } & -0.054 & $-0.629 * *$ & -0.119 & -0.369 & 0.164 & 0.447 \\
\hline & $(0.28)$ & $(0.26)$ & $(0.29)$ & $(0.33)$ & $(0.36)$ & $(0.35)$ \\
\hline \multirow[t]{2}{*}{ Closed-end RE loans } & $0.803^{* *}$ & 0.190 & 0.199 & -0.257 & $-0.618^{* *}$ & $-0.905^{* * *}$ \\
\hline & $(0.35)$ & $(0.23)$ & $(0.24)$ & $(0.28)$ & $(0.30)$ & $(0.32)$ \\
\hline \multirow[t]{2}{*}{ Open-end RE loans } & 0.366 & -0.018 & -0.470 & -0.966 & $-4.449 * * *$ & $-5.316 * * *$ \\
\hline & $(1.52)$ & $(1.07)$ & $(1.24)$ & $(1.42)$ & $(1.53)$ & (1.58) \\
\hline \multirow[t]{2}{*}{ Other RE loans } & -0.324 & 0.047 & 0.348 & -0.013 & -0.348 & $-0.680^{* *}$ \\
\hline & $(0.32)$ & $(0.23)$ & $(0.27)$ & $(0.29)$ & $(0.30)$ & $(0.31)$ \\
\hline \multirow{3}{*}{\multicolumn{3}{|c|}{$\begin{array}{l}\text { Lender and Year FE } \\
\text { Additional Controls } \\
\text { Number of observations }\end{array}$}} & \multicolumn{2}{|c|}{ YES } & & \\
\hline & & & \multirow{2}{*}{\multicolumn{2}{|c|}{$\begin{array}{c}\text { YES } \\
7,350\end{array}$}} & & \\
\hline & & & & & & \\
\hline \multicolumn{2}{|l|}{$\mathrm{R} 2$} & & \multicolumn{2}{|c|}{0.616} & & \\
\hline
\end{tabular}

(b) Lenders with Assets $>\$ 1$ billion

\begin{tabular}{|c|c|c|c|c|c|c|}
\hline \multirow[b]{2}{*}{ COEFFICIENT } & \multicolumn{6}{|c|}{ Dependent Variable: Lit } \\
\hline & $\gamma$ & $\delta 2006$ & $\delta 2007$ & $\delta 2008$ & $\delta 2009$ & $\delta 2010$ \\
\hline Lines of credit for RE loans & $\begin{array}{c}3.021 * * \\
(1.37)\end{array}$ & $\begin{array}{c}-2.551^{*} \\
(1.31)\end{array}$ & $\begin{array}{c}-2.539^{*} \\
(1.42)\end{array}$ & $\begin{array}{c}-2.628^{* *} \\
(1.30)\end{array}$ & $\begin{array}{l}0.246 \\
(1.93)\end{array}$ & $\begin{array}{l}0.924 \\
(2.14)\end{array}$ \\
\hline Core-deposit funding & $\begin{array}{l}-0.534 \\
(0.37)\end{array}$ & $\begin{array}{l}0.415 \\
(0.32)\end{array}$ & $\begin{array}{l}0.681^{*} \\
(0.38)\end{array}$ & $\begin{array}{c}1.290 * * * \\
(0.39)\end{array}$ & $\begin{array}{c}0.941 * * \\
(0.47)\end{array}$ & $\begin{array}{l}0.858^{*} \\
(0.46)\end{array}$ \\
\hline log Assets & $\begin{array}{l}-0.000 \\
(0.00)\end{array}$ & $\begin{array}{l}0.001 \\
(0.00)\end{array}$ & $\begin{array}{l}0.001 \\
(0.00)\end{array}$ & $\begin{array}{l}0.001 \\
(0.00)\end{array}$ & $\begin{array}{l}-0.001 \\
(0.00)\end{array}$ & $\begin{array}{l}0.001 \\
(0.00)\end{array}$ \\
\hline Tier 1 leverage ratio & $\begin{array}{l}3.790^{*} \\
(2.07)\end{array}$ & $\begin{array}{l}-1.407 \\
(2.23)\end{array}$ & $\begin{array}{l}-3.256 \\
(2.51)\end{array}$ & $\begin{array}{l}2.316 \\
(2.71)\end{array}$ & $\begin{array}{l}-2.348 \\
(2.30)\end{array}$ & $\begin{array}{l}-1.649 \\
(2.60)\end{array}$ \\
\hline Asset liquidity & $\begin{array}{l}0.549 \\
(0.47)\end{array}$ & $\begin{array}{c}-1.234^{* * *} \\
(0.46)\end{array}$ & $\begin{array}{c}-1.419 * * \\
(0.58)\end{array}$ & $\begin{array}{c}-1.070^{*} \\
(0.55)\end{array}$ & $\begin{array}{l}-0.825 \\
(0.62)\end{array}$ & $\begin{array}{l}-0.294 \\
(0.54)\end{array}$ \\
\hline Closed-end RE loans & $\begin{array}{l}-0.113 \\
(0.50)\end{array}$ & $\begin{array}{l}0.700 \\
(0.46)\end{array}$ & $\begin{array}{l}0.349 \\
(0.48)\end{array}$ & $\begin{array}{l}0.174 \\
(0.52)\end{array}$ & $\begin{array}{l}-0.232 \\
(0.55)\end{array}$ & $\begin{array}{l}0.143 \\
(0.58)\end{array}$ \\
\hline Open-end RE loans & $\begin{array}{l}1.784 \\
(2.15)\end{array}$ & $\begin{array}{l}1.117 \\
(1.60)\end{array}$ & $\begin{array}{l}-0.006 \\
(1.69)\end{array}$ & $\begin{array}{c}-2.937^{*} \\
(1.76)\end{array}$ & $\begin{array}{c}-6.500 * * * \\
(2.36)\end{array}$ & $\begin{array}{c}-5.402^{* *} \\
(2.36)\end{array}$ \\
\hline Other RE loans & $\begin{array}{l}-0.130 \\
(0.43)\end{array}$ & $\begin{array}{l}0.449 \\
(0.33)\end{array}$ & $\begin{array}{l}0.288 \\
(0.35)\end{array}$ & $\begin{array}{l}0.085 \\
(0.42)\end{array}$ & $\begin{array}{c}-0.936 * * \\
(0.47)\end{array}$ & $\begin{array}{r}-0.721 \\
(0.46)\end{array}$ \\
\hline $\begin{array}{l}\text { Lender and Year FE } \\
\text { Additional Controls } \\
\text { Number of observations }\end{array}$ & & & & & & \\
\hline R2 & & & & & & \\
\hline
\end{tabular}

Notes: Estimated second-stage coefficients for the specification shown in Equation 4 for lenders with Assets $<\$ 1$ billion (panel a) and lenders with Assets $>\$ 1$ billion (panel b). The richer sets of covariates were used both in the first and second stages. The first column shows the base 2004 values and the other columns show structural adjustments from 2004 levels. Standard errors in parentheses are clustered at the bank level. The levels of statistical significance are ${ }^{* * *} \mathrm{p}<0.01,{ }^{* *} \mathrm{p}<0.05$, and ${ }^{*} \mathrm{p}<0.10$ 
Table XII

Second-stage coefficients for the model shown in Equation 6 (TED spread interactions)

\begin{tabular}{|c|c|c|c|c|c|c|}
\hline SAMPLE & \multicolumn{2}{|c|}{ ALL BANKS } & \multicolumn{2}{|c|}{ ASSETS $<\$ 1 b i l$} & \multicolumn{2}{|c|}{ ASSETS $>\$ 1 \mathrm{bil}$} \\
\hline COEFFICIENT & $\gamma$ (BASE) & $\delta(x T E D)$ & $\gamma$ (BASE) & $\delta(x T E D)$ & $\gamma$ (BASE) & $\delta(x T E D)$ \\
\hline Lines of credit for RE loans & $\begin{array}{c}1.614 * * * \\
(0.56)\end{array}$ & $\begin{array}{c}-1.649 * * * \\
(0.45)\end{array}$ & $\begin{array}{l}1.158^{*} \\
(0.67)\end{array}$ & $\begin{array}{c}-1.540 * * * \\
(0.57)\end{array}$ & $\begin{array}{c}3.124 * * * \\
(0.97)\end{array}$ & $\begin{array}{c}-2.038 * * * \\
(0.69)\end{array}$ \\
\hline Core-deposit funding & $\begin{array}{l}-0.071 \\
(0.19)\end{array}$ & $\begin{array}{c}0.377^{* *} \\
(0.15)\end{array}$ & $\begin{array}{l}-0.021 \\
(0.24)\end{array}$ & $\begin{array}{l}0.261 \\
(0.20)\end{array}$ & $\begin{array}{l}-0.239 \\
(0.33)\end{array}$ & $\begin{array}{c}0.652^{* * *} \\
(0.22)\end{array}$ \\
\hline log Assets & $\begin{array}{l}0.001 \\
(0.00)\end{array}$ & $\begin{array}{l}0.000 \\
(0.00)\end{array}$ & $\begin{array}{l}0.002 \\
(0.00)\end{array}$ & $\begin{array}{l}0.001 \\
(0.00)\end{array}$ & $\begin{array}{l}0.000 \\
(0.00)\end{array}$ & $\begin{array}{l}0.000 \\
(0.00)\end{array}$ \\
\hline Tier 1 leverage ratio & $\begin{array}{l}1.091 \\
(0.93)\end{array}$ & $\begin{array}{l}1.162^{*} \\
(0.65)\end{array}$ & $\begin{array}{l}1.075 \\
(1.12)\end{array}$ & $\begin{array}{l}1.089 \\
(0.73)\end{array}$ & $\begin{array}{l}0.857 \\
(1.62)\end{array}$ & $\begin{array}{l}2.067 \\
(1.48)\end{array}$ \\
\hline Asset liquidity & $\begin{array}{l}0.067 \\
(0.23)\end{array}$ & $\begin{array}{c}-0.411^{* *} \\
(0.18)\end{array}$ & $\begin{array}{l}0.029 \\
(0.26)\end{array}$ & $\begin{array}{l}-0.310 \\
(0.21)\end{array}$ & $\begin{array}{l}0.199 \\
(0.42)\end{array}$ & $\begin{array}{c}-0.738^{* *} \\
(0.34)\end{array}$ \\
\hline Closed-end RE loans & $\begin{array}{l}0.483^{*} \\
(0.28)\end{array}$ & $\begin{array}{l}0.163 \\
(0.14)\end{array}$ & $\begin{array}{l}0.451 \\
(0.32)\end{array}$ & $\begin{array}{l}0.202 \\
(0.16)\end{array}$ & $\begin{array}{l}0.455 \\
(0.52)\end{array}$ & $\begin{array}{l}-0.015 \\
(0.30)\end{array}$ \\
\hline Open-end RE loans & $\begin{array}{l}-1.365 \\
(1.14)\end{array}$ & $\begin{array}{l}0.879 \\
(0.68)\end{array}$ & $\begin{array}{l}-2.013 \\
(1.37)\end{array}$ & $\begin{array}{l}1.243 \\
(0.83)\end{array}$ & $\begin{array}{l}0.931 \\
(1.75)\end{array}$ & $\begin{array}{l}-0.028 \\
(0.99)\end{array}$ \\
\hline Other RE loans & $\begin{array}{c}-0.544^{* * *} \\
(0.24)\end{array}$ & $\begin{array}{c}0.297 * * \\
(0.14)\end{array}$ & $\begin{array}{c}-0.612^{* *} \\
(0.29)\end{array}$ & $\begin{array}{l}0.270 \\
(0.17)\end{array}$ & $\begin{array}{r}-0.293 \\
(0.38)\end{array}$ & $\begin{array}{l}0.249 \\
(0.24)\end{array}$ \\
\hline $\begin{array}{l}\text { Lender and Year FE } \\
\text { Additional Controls } \\
\text { Number of observations }\end{array}$ & & & & & & $\begin{array}{l}\text { ES } \\
\text { ES } \\
005\end{array}$ \\
\hline R2 & & & & & & 58 \\
\hline
\end{tabular}

Notes: Estimated second-stage coefficients for the specification shown in Equation 6 (TED spread interactions). The richer sets of covariates were used both in the first and second stage. The effect of liquidity risk on credit is captured by the interaction terms (xTED columns) for Lines of credit for RE loans and Core-deposit funding. Standard errors are clustered at the bank level. The levels of statistical significance are ${ }^{* * *} \mathrm{p}<0.01,{ }^{* *} \mathrm{p}<0.05$, and ${ }^{*} \mathrm{p}<0.10$

Table XIII

Actual vs predicted volume of mortgage originations

\begin{tabular}{rcccccc}
\hline VARIABLE & \multicolumn{7}{c}{ VOLUME OF NEW ORIGINATIONS (\$bil) } \\
\hline YEAR & 2004 & 2006 & 2007 & 2008 & 2009 & 2010 \\
\hline ACTUAL & 361.8 & 471.5 & 392.6 & 212.0 & 164.0 & 148.5 \\
PREDICTED & 369.6 & 487.4 & 406.0 & 219.6 & 167.4 & 151.1 \\
\hline \hline
\end{tabular}

Notes: The first row (ACTUAL) lists the actual dollar volume of mortgage originations extracted from the data. The second row (PREDICTED) lists the expected dollar volume of mortgage originations predicted by the first stage model with the richer set of covariates shown in Equation 5. 
Table XIV

Economic impact of liquidity risk

(a) Dollar volume of increase in originations

\begin{tabular}{|c|c|c|c|c|c|c|}
\hline \multirow{3}{*}{$\frac{\text { MODEL }}{\text { SOURCE }}$} & \multicolumn{6}{|c|}{ EXPECTED INCREASE IN VOLUME OF ORIGINATIONS (\$\$bil) } \\
\hline & \multicolumn{3}{|c|}{ STRUCTURAL ADJUSTMENTS } & \multicolumn{3}{|c|}{ TED SPREAD } \\
\hline & Lines of Credit & Core Deposits & Both & Lines of Credit & Core Deposits & Both \\
\hline 2007 & 16.8 & 17.8 & 31.9 & 9.8 & 12.1 & 20.9 \\
\hline 2008 & 8.4 & 15.8 & 21.8 & 8.5 & 10.9 & 17.8 \\
\hline 2009 & -0.5 & 8.5 & 8.1 & 1.0 & 1.8 & 2.8 \\
\hline TOTAL & 24.7 & 42.0 & 61.9 & 19.4 & 24.8 & 41.5 \\
\hline
\end{tabular}

(b) Dollar volume of increase in originations as a percentage of expected base volume

\begin{tabular}{|c|c|c|c|c|c|c|}
\hline \multirow{3}{*}{$\begin{array}{l}\text { MODEL } \\
\text { SOURCE }\end{array}$} & \multicolumn{6}{|c|}{ EXPECTED PERCENTAGE INCREASE IN VOLUME OF ORIGINATIONS (\%) } \\
\hline & \multicolumn{3}{|c|}{ STRUCTURAL ADJUSTMENTS } & \multicolumn{3}{|c|}{ TED SPREAD } \\
\hline & Lines of Credit & Core Deposits & Both & Lines of Credit & Core Deposits & Both \\
\hline 2007 & 4.1 & 4.4 & 7.9 & 2.4 & 3.0 & 5.2 \\
\hline 2008 & 3.8 & 7.2 & 9.9 & 3.9 & 5.0 & 8.1 \\
\hline 2009 & -0.3 & 5.1 & 4.8 & 0.6 & 1.1 & 1.7 \\
\hline TOTAL & 3.1 & 5.3 & 7.8 & 2.4 & 3.1 & 5.2 \\
\hline
\end{tabular}

Notes: The table shows the increase in mortgage originations that would have resulted had the banks not adjusted their responses to liquidity risk during the crisis, for each source of liquidity risk independently or for both sources combined. To compute the estimates, for the model with flexible structural breaks I set the interaction terms to 0, and for the model with the TED spread interactions I set the TED spread back to its 2004 level. Panel (a) shows the expected increases in the dollar volume of loan originations in \$billion and panel (b) shows the same increases as a percentage of the expected base volume for each year.

Table XV

Economic impact of liquidity risk under a "reduced exposure" counterfactual

(a) Dollar volume of increase in originations

\begin{tabular}{|c|c|c|c|c|c|c|}
\hline \multirow{3}{*}{$\frac{\text { MODEL }}{\text { SOURCE }}$} & \multicolumn{6}{|c|}{ EXPECTED INCREASE IN VOLUME OF ORIGINATIONS (\$\$bil) } \\
\hline & \multicolumn{3}{|c|}{ STRUCTURAL ADJUSTMENTS } & \multicolumn{3}{|c|}{ TED SPREAD } \\
\hline & Lines of Credit & Core Deposits & Both & Lines of Credit & Core Deposits & Both \\
\hline 2007 & 9.1 & 6.3 & 15.0 & 7.0 & 5.8 & 12.5 \\
\hline 2008 & 4.5 & 6.0 & 10.1 & 5.4 & 4.7 & 9.8 \\
\hline 2009 & -0.2 & 2.5 & 2.3 & 1.0 & 1.0 & 1.9 \\
\hline TOTAL & 13.3 & 14.8 & 27.4 & 13.4 & 11.4 & 24.2 \\
\hline
\end{tabular}

(b) Dollar volume of increase in originations as a percentage of expected base volume

\begin{tabular}{|c|c|c|c|c|c|c|}
\hline \multirow{3}{*}{$\frac{\text { MODEL }}{\text { SOURCE }}$} & \multicolumn{6}{|c|}{ EXPECTED PERCENTAGE INCREASE IN VOLUME OF ORIGINATIONS (\%) } \\
\hline & \multicolumn{3}{|c|}{ STRUCTURAL ADJUSTMENTS } & \multicolumn{3}{|c|}{ TED SPREAD } \\
\hline & Lines of Credit & Core Deposits & Both & Lines of Credit & Core Deposits & Both \\
\hline 2007 & 2.2 & 1.6 & 3.7 & 1.7 & 1.4 & 3.1 \\
\hline 2008 & 2.0 & 2.7 & 4.6 & 2.5 & 2.2 & 4.5 \\
\hline 2009 & -0.1 & 1.5 & 1.4 & 0.6 & 0.6 & 1.1 \\
\hline TOTAL & 1.7 & 1.9 & 3.5 & 1.7 & 1.4 & 3.1 \\
\hline
\end{tabular}

Notes: The table shows the increase in mortgage originations that would have resulted had the banks operated during the crisis with a one standard deviation reduction in each source of liquidity risk independently or jointly. The adjustments to the levels of liquidity risk are censored where needed to ensure that (i) the adjusted values of unused lines of credit do not fall below 0 and (ii) the sum of the adjusted core deposit and equity capital ratios does not exceed 1. Panel (a) shows the expected increases in the dollar volume of loan originations in \$billion and panel (b) shows the same increases as a percentage of the expected base volume for each year. 
Figure I

Stylized model of the loan approval process

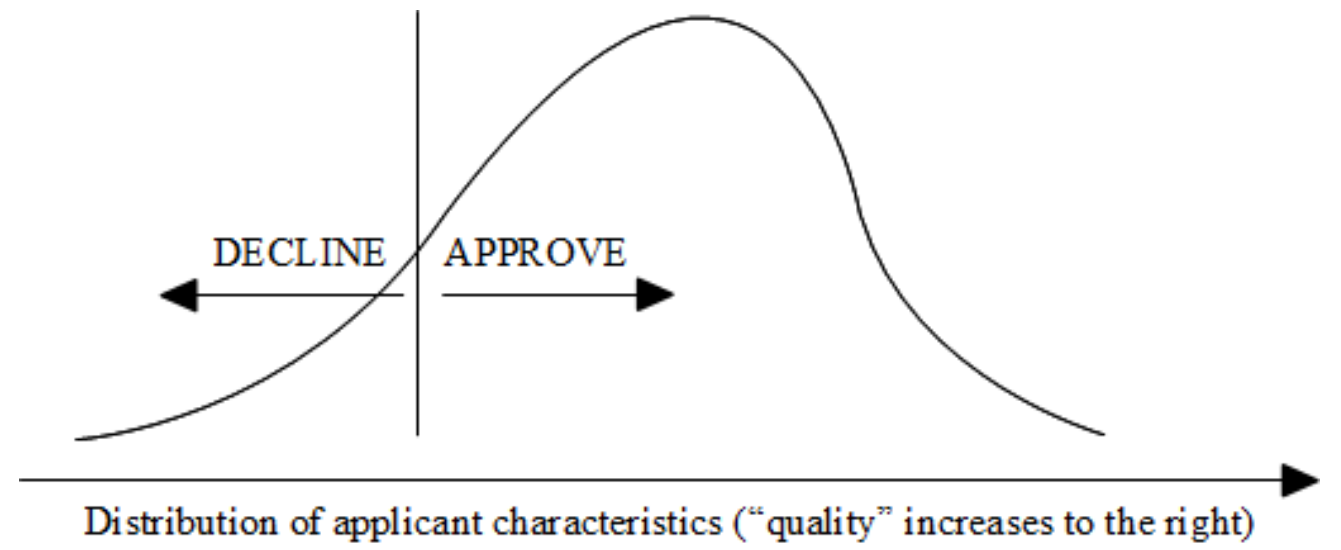

(a) Loan supply approval as targeting a distributional cutoff

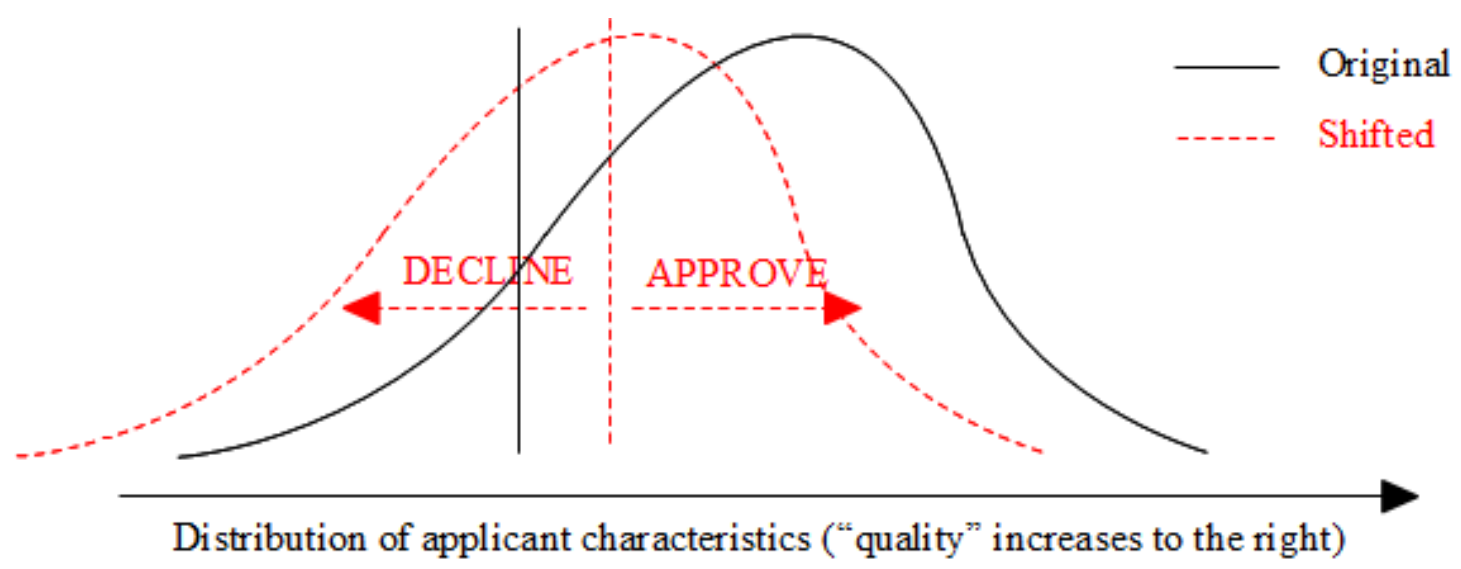

(b) Contraction of lending due to a simultaneous shifts in demand and supply 
Figure II

Balance-sheet dynamics

\begin{tabular}{|l|l|}
\hline \multicolumn{2}{|c|}{ BALANCE SHEET } \\
\hline \multicolumn{1}{|c|}{ ASSETS } & \multicolumn{1}{c|}{ LIABILITIES } \\
\hline Liquid assets & Core deposits \\
Mortgage loans & Wholesale funding \\
Other loans & Capital \\
\hline
\end{tabular}

OFF- BALANCE SHEET

Unused lines of credit

(a) Stylized bank balance sheet and off-balance sheet exposure

\begin{tabular}{|c|c|}
\hline \multicolumn{2}{|c|}{ BALANCE SHEET } \\
\hline ASSETS & LIABILITIES \\
\hline $\begin{array}{ll}\text { Liquid assets } & \mathbf{- \$ 1} \\
\text { Mortgage loans } & \\
\text { Other loans } & \end{array}$ & $\begin{array}{l}\text { Core deposits } \\
\text { Wholesale funding } \quad \mathbf{- \$ 1} \\
\text { Capital }\end{array}$ \\
\hline
\end{tabular}

\begin{tabular}{|l|}
\hline OFF- BALANCE SHEET \\
\hline Unused lines of credit \\
\hline
\end{tabular}

(b) Balance sheet adjustments for a $\$ 1$ withdrawal of wholesale funding

\begin{tabular}{|c|c|}
\hline \multicolumn{2}{|c|}{ BALANCE SHEET } \\
\hline ASSETS & LIABILITIES \\
\hline Liquid assets & Core deposits \\
\hline Mortgage loans & Wholesale funding \\
\hline Other loans & Capital \\
\hline
\end{tabular}

\begin{tabular}{|l|}
\hline OFF- BALANCE SHEET \\
\hline Unused lines of credit $\quad \mathbf{- \$ 1}$ \\
\hline
\end{tabular}

(c) Balance sheet and off-balance sheet adjustments for a $\$ 1$ drawdown on a line of credit

\begin{tabular}{|c|c|}
\hline \multicolumn{2}{|c|}{ BALANCE SHEET } \\
\hline ASSETS & LIABILITIES \\
\hline Liquid assets & Core deposits \\
\hline Mortgage loans $+\$ 1$ & Wholesale funding \\
\hline Other loans & Capital \\
\hline
\end{tabular}

\begin{tabular}{|l|}
\hline OFF- BALANCE SHEET \\
\hline Unused lines of credit \\
\hline
\end{tabular}

(d) Balance sheet adjustments for a $\$ 1$ mortgage loan origination

Notes: Panel (a) shows a stylized balance sheet for a bank. Panels (b), (c) and (d) show respectively a $\$ 1$ withdrawal of wholesale funding, a $\$ 1$ drawdown on an unused line of credit, and a $\$ 1$ mortgage loan origination. 
Figure III

Mortgage loan originations for commercial banks for 2004, 2006-2010

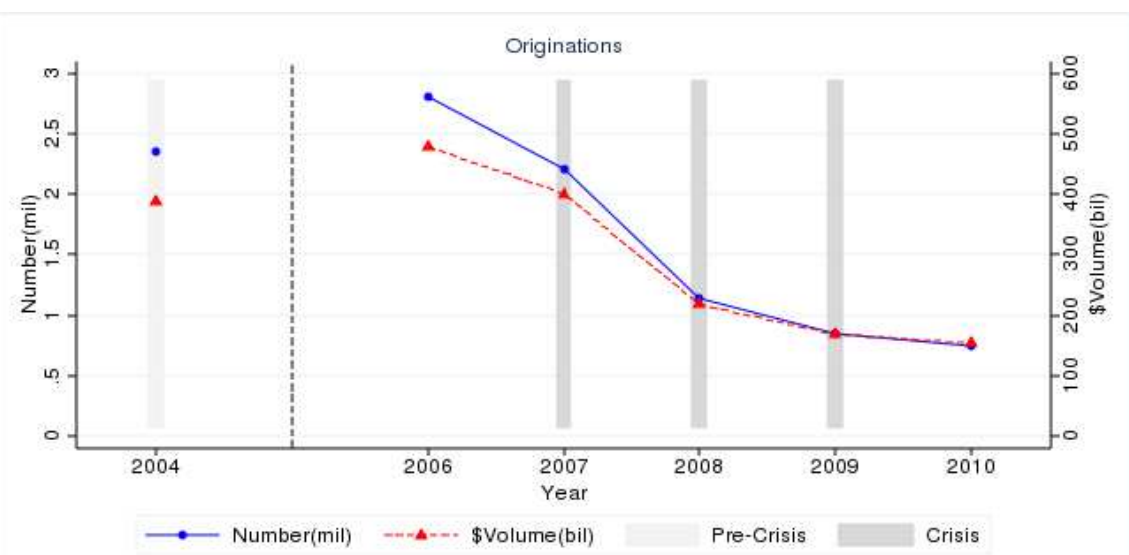

Notes: The left axis measures the number (million) and the right axis the dollar volume (\$billion) of originations.

Figure IV

Mortgage loan applications to commercial banks for 2004, 2006-2010

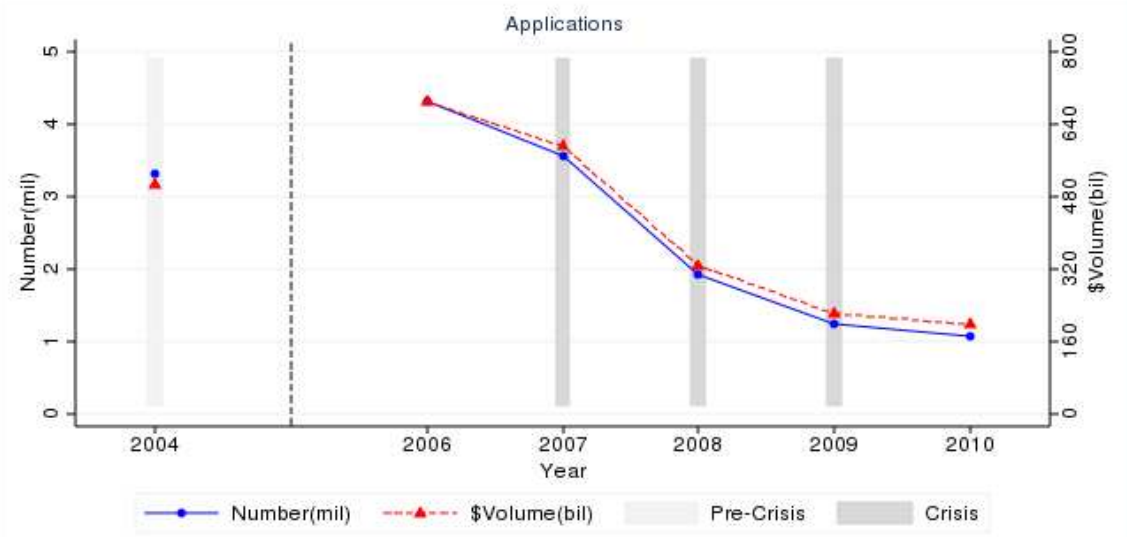

Notes: The left axis measures the number (million) and the right axis the dollar volume (\$billion) of applications.

Figure V

Mortgage loan approval rates of commercial banks for 2004, 2006-2010

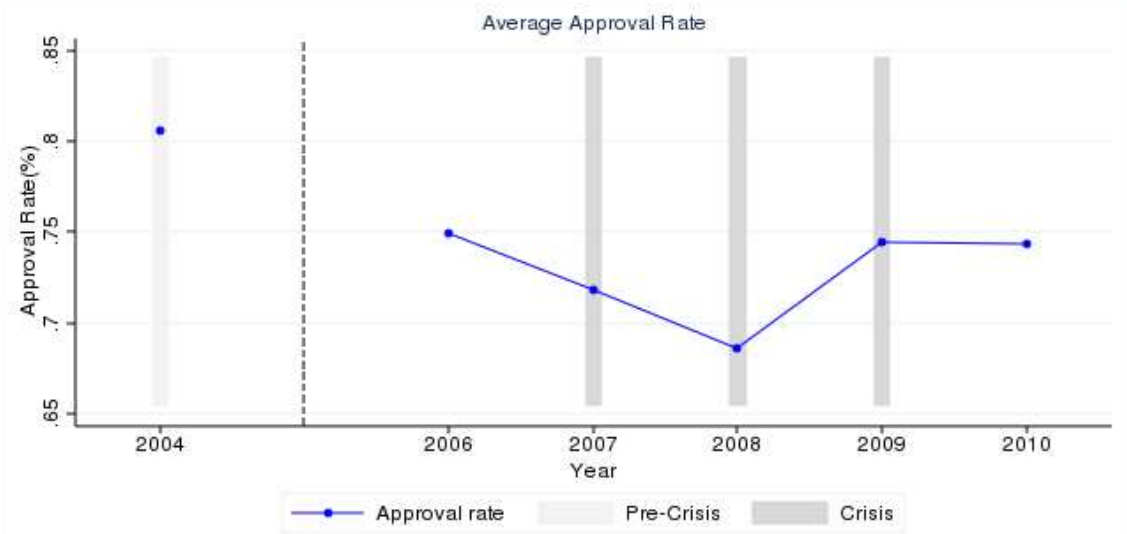


Figure VI

Core-deposit funding scaled by total assets for small and large lenders

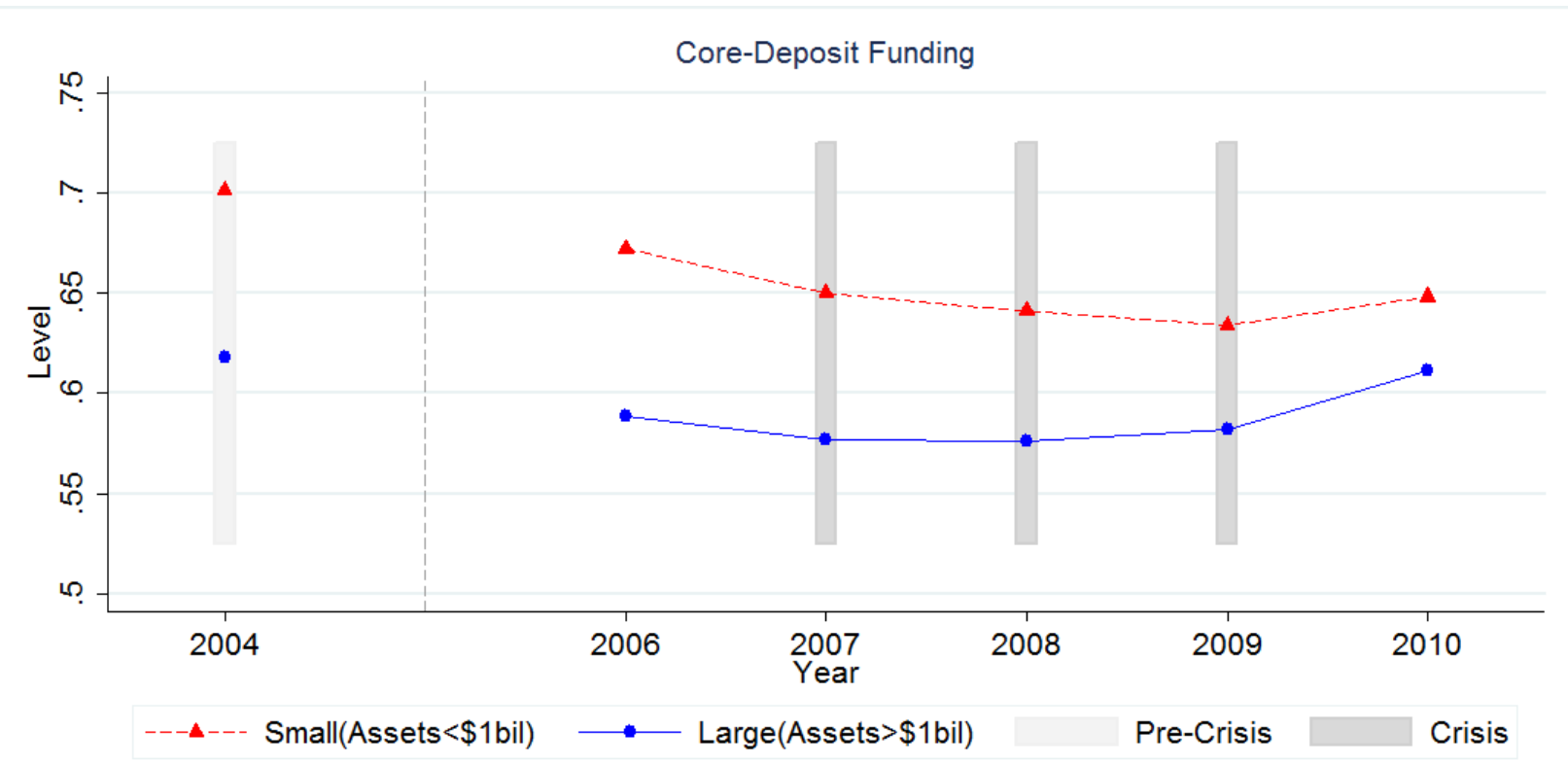

Notes: This figure shows the average level of core-deposit funding for small lenders (Assets $<\$ 1$ billion) and large lenders (Assets $>\$ 1$ billion) across time. The values correspond to beginning of year levels.

Figure VII

Unused commitments for real estate loans scaled by total assets for small and large lenders

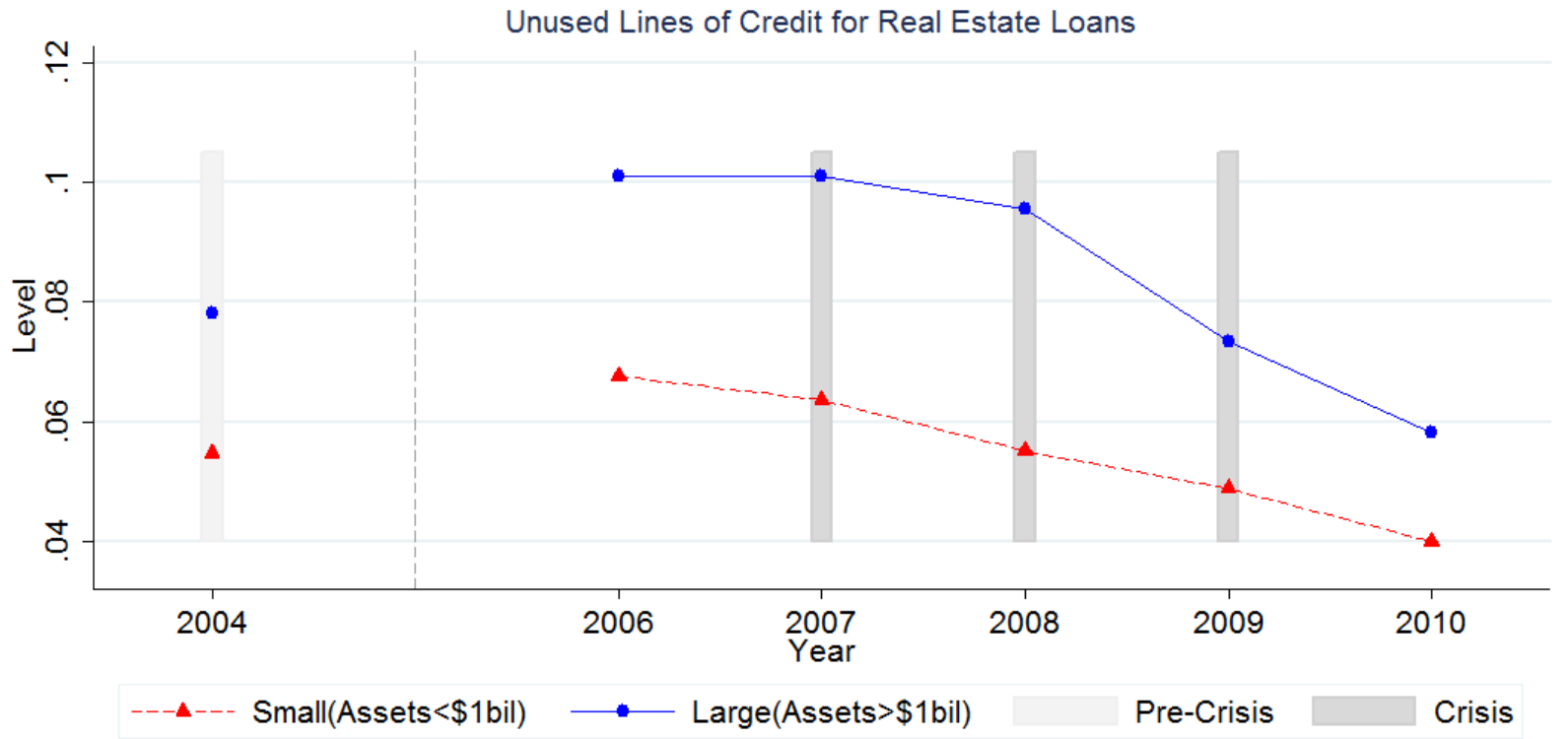

Notes: This figure shows the average level of off-balance sheet exposure to unused lines of credit for real estate loans, for small lenders (Assets $<\$ 1$ billion) and large lenders (Assets $>\$ 1$ billion) across time. The values correspond to beginning of year levels. 
Figure VIII

Level and confidence intervals for the coefficient for core deposits

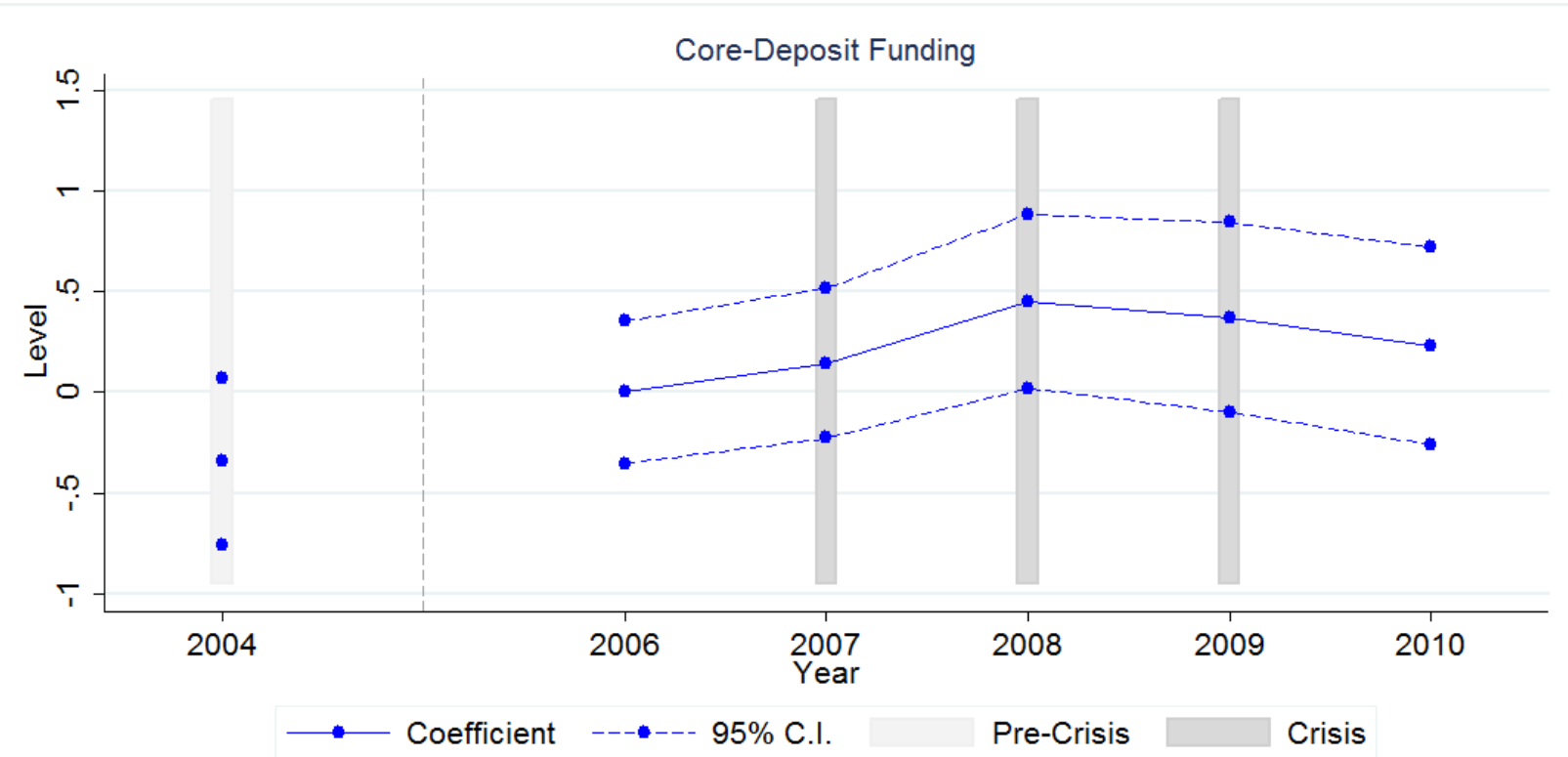

Notes: This figure displays the point estimates and $95 \%$ confidence intervals for the coefficient for core deposits in the specification shown in Equation 3. Coefficients are at annual levels. The effect of liquidity risk on credit supply is the structural adjustment from 2004 levels.

Figure IX

Level and confidence intervals for the coefficient for unused lines of credit for real estate loans

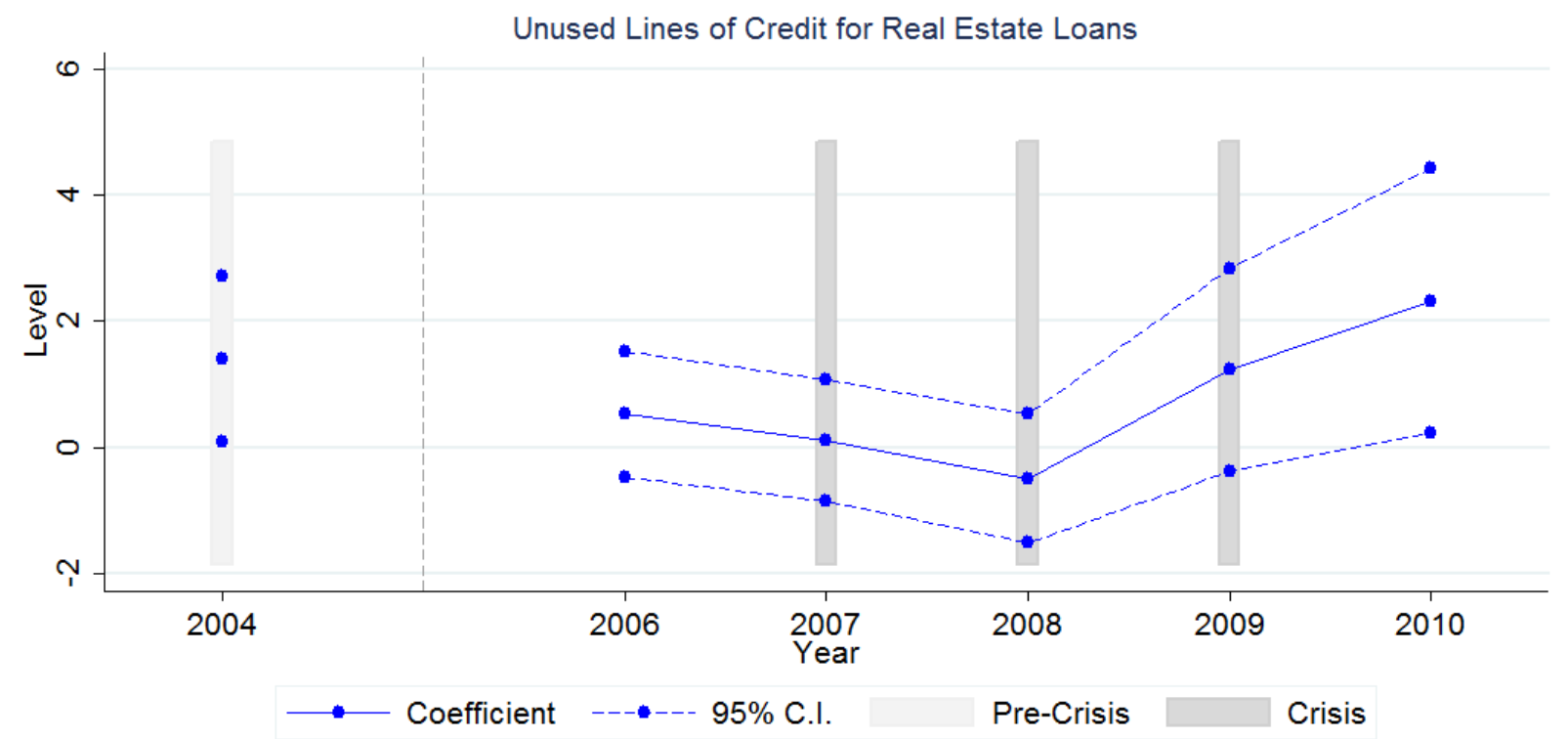

Notes: This figure displays the point estimates and $95 \%$ confidence intervals for the coefficient for unused lines of credit for real estate loans in the specification shown in Equation 3. Coefficients are at annual levels. The effect of liquidity risk on credit supply is the structural adjustment from 2004 levels. 
Figure X

Structural breaks and confidence intervals for the coefficient for core deposits

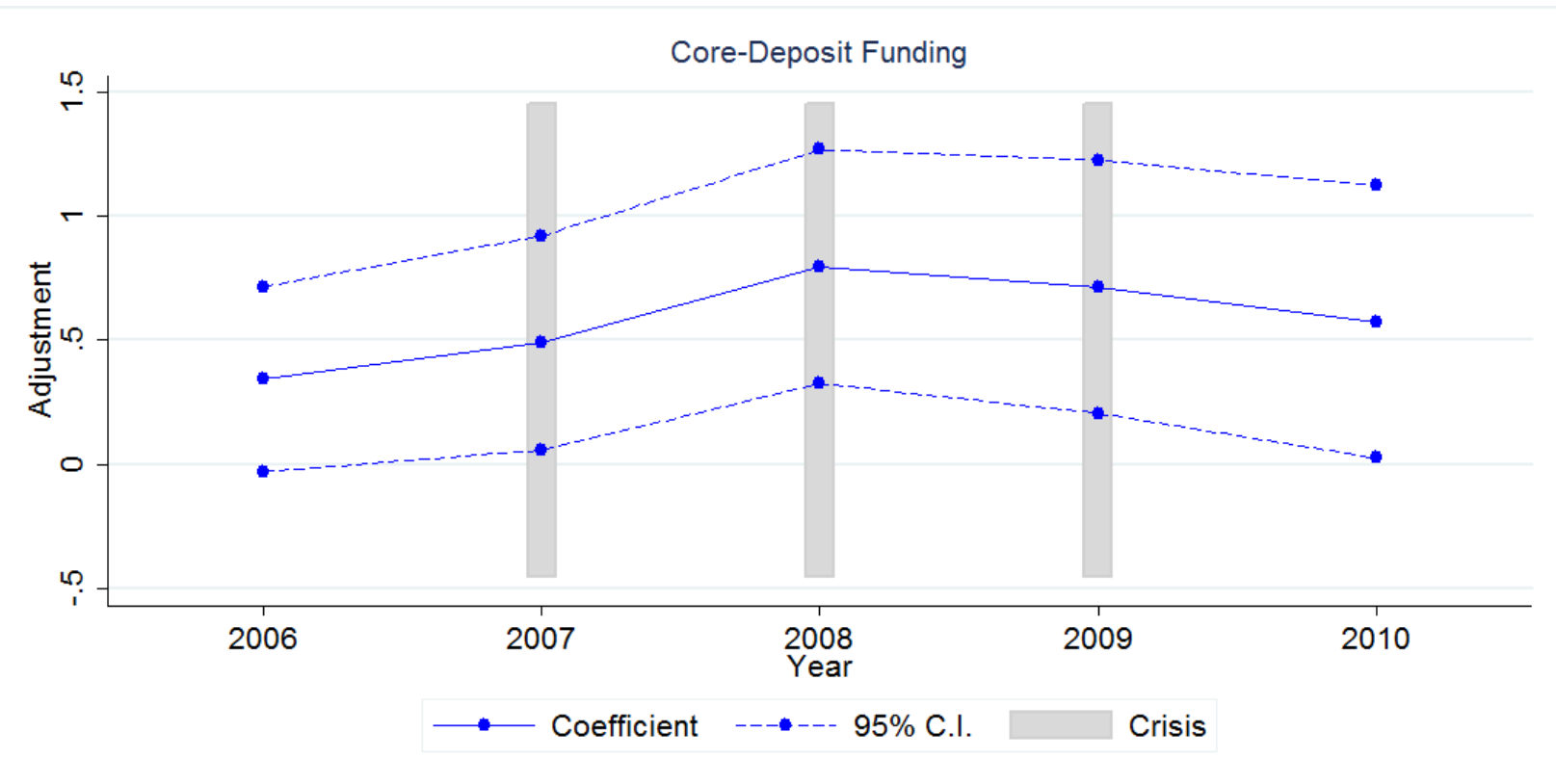

Notes: This figure displays point estimates and $95 \%$ confidence intervals for the coefficients for core deposits obtained by estimating the specification shown in Equation 4. Coefficients are structural breaks from 2004 levels and capture the effect of liquidity risk on credit supply.

Figure XI

Structural breaks and confidence intervals for the coefficient for unused lines of credit

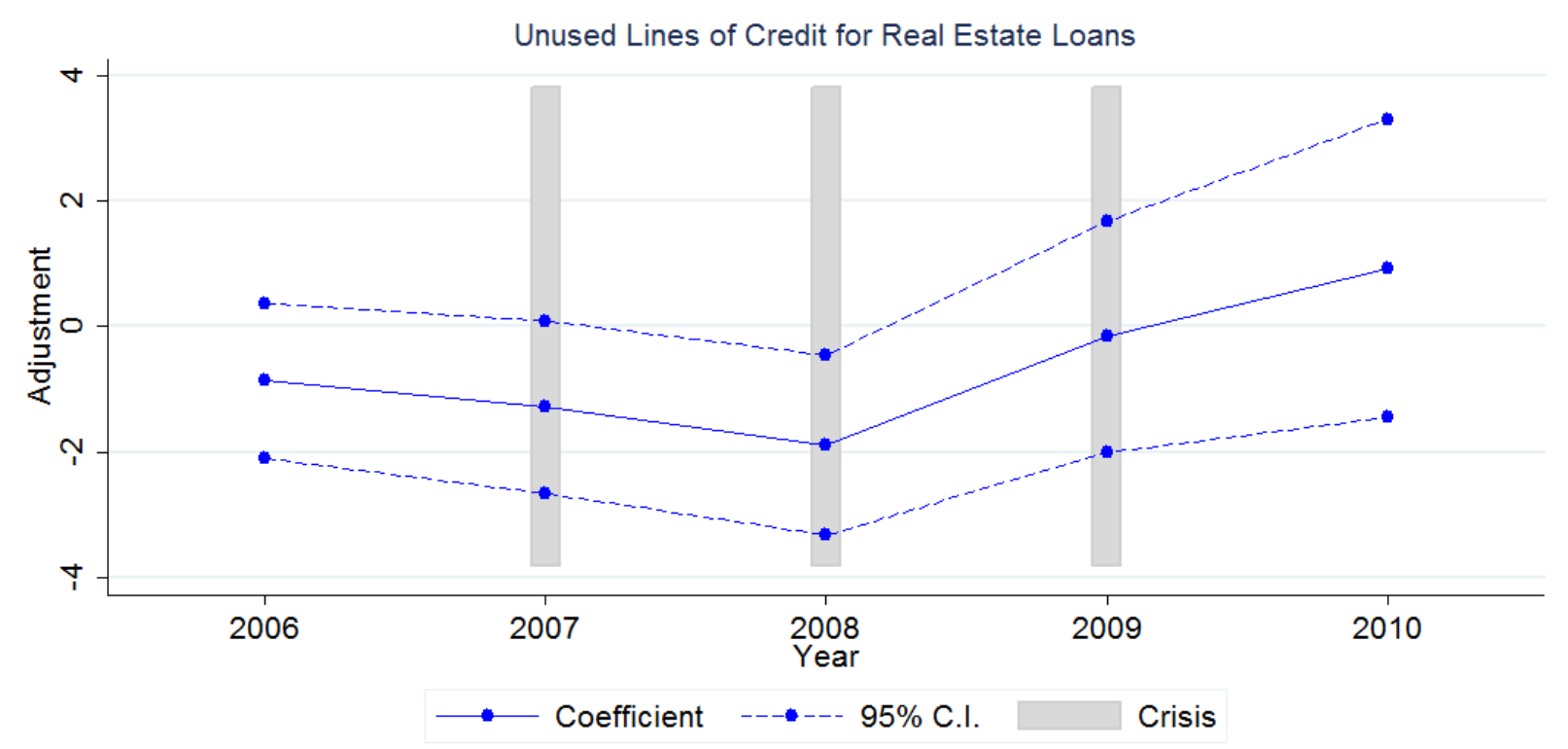

Notes: This figure displays point estimates and 95\% confidence intervals for the coefficients for unused lines of credit obtained by estimating the specification shown in Equation 4. Coefficients are structural breaks from 2004 levels and capture the effect of liquidity risk on credit supply. 
Figure XII

Mortgage loan approval rates of commercial banks for 2004, 2006-10 by lender size

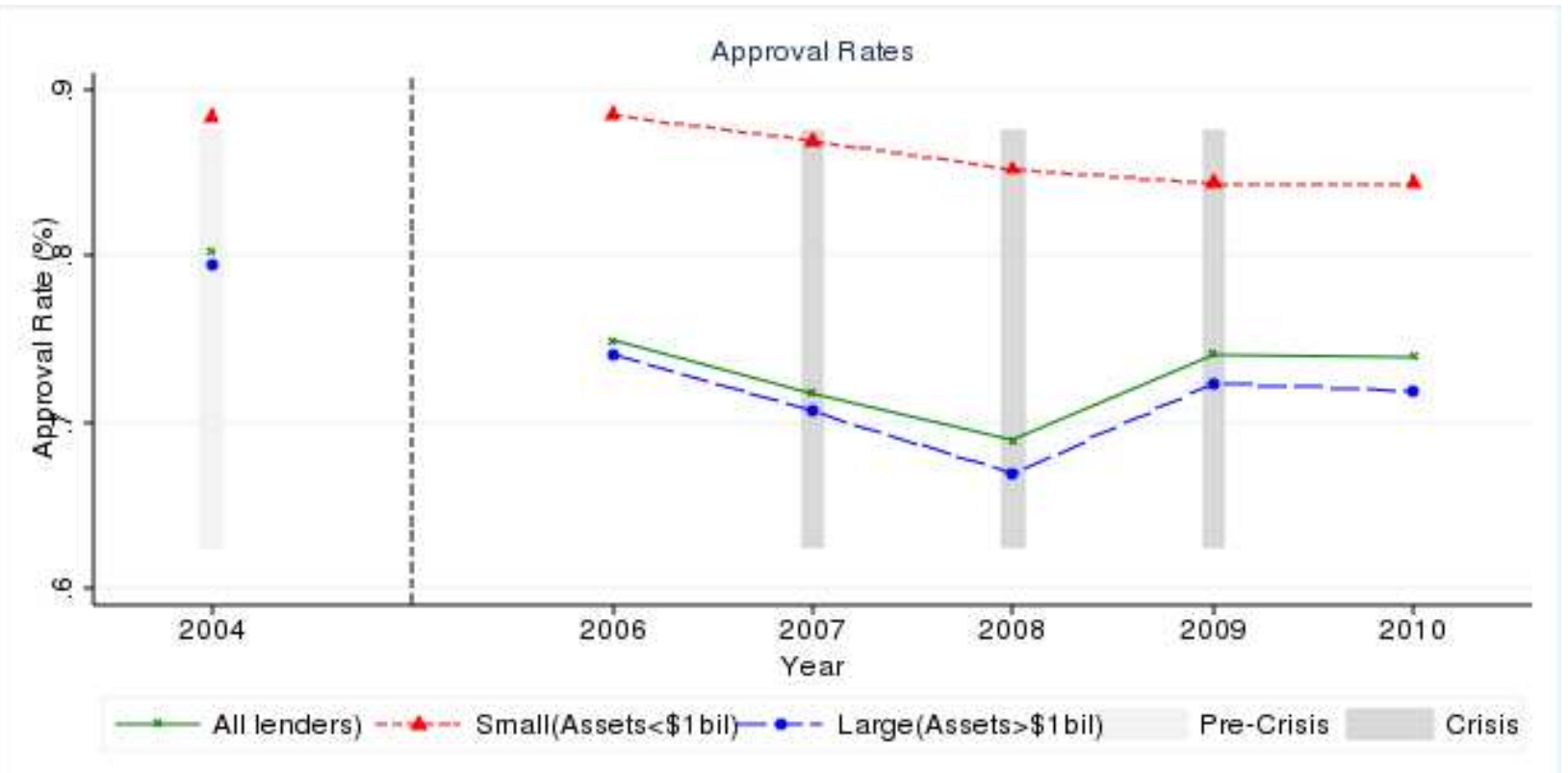

Notes: This figure displays approval rates for mortgage loan applications to commercial banks for 2004, 2006-10. Approval rates are shown for all banks, but also separately for the split sample of small banks (Assets $<\$ 1$ billion) and large banks (Assets $>\$ 1$ billion) 
Figure XIII

The TED spread for the period 2000-2011

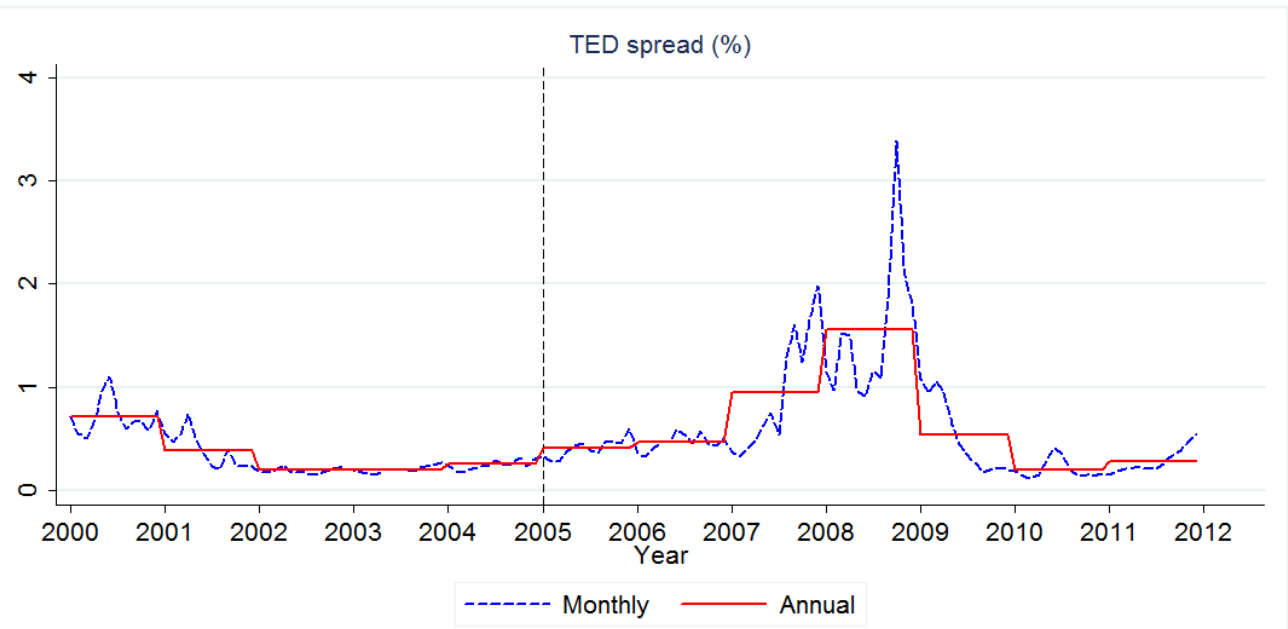

Notes: This figure shows monthly and annual averages of the TED spread from 2000 to 2011. The TED spread measures funding stresses in the banking sector and is defined as the difference in interest rates between 3-month LIBOR and the 3-month Treasury bill.

Figure XIV

The S\&P/Case-Shiller U.S. National Index Level seasonally adjusted for 2000-2011

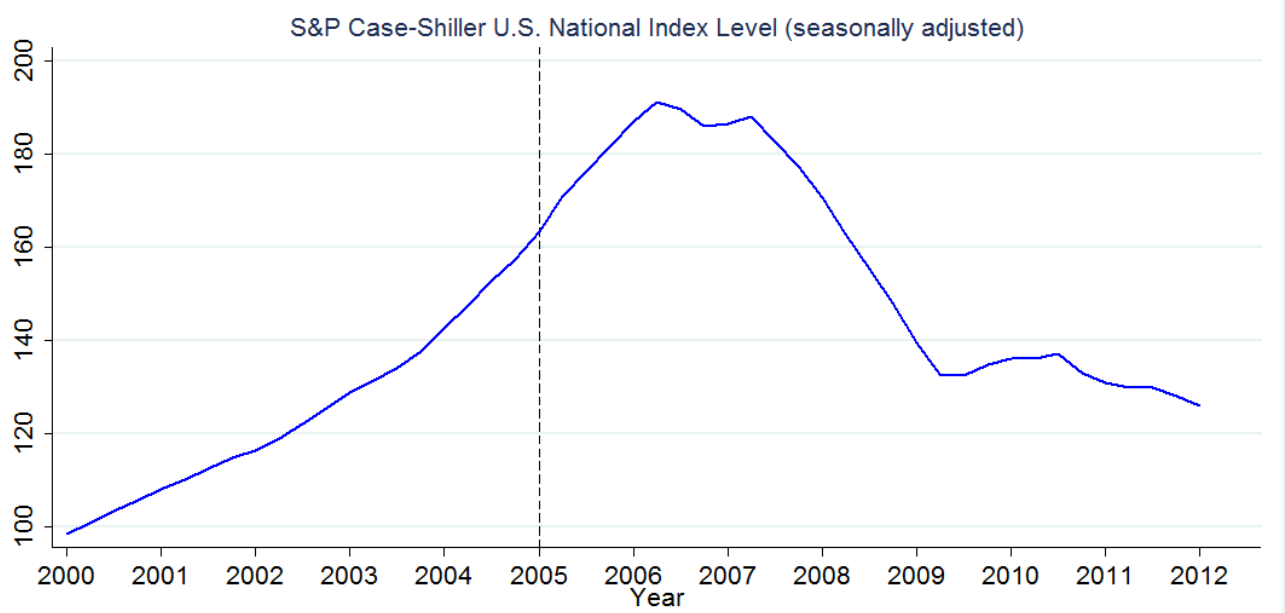

